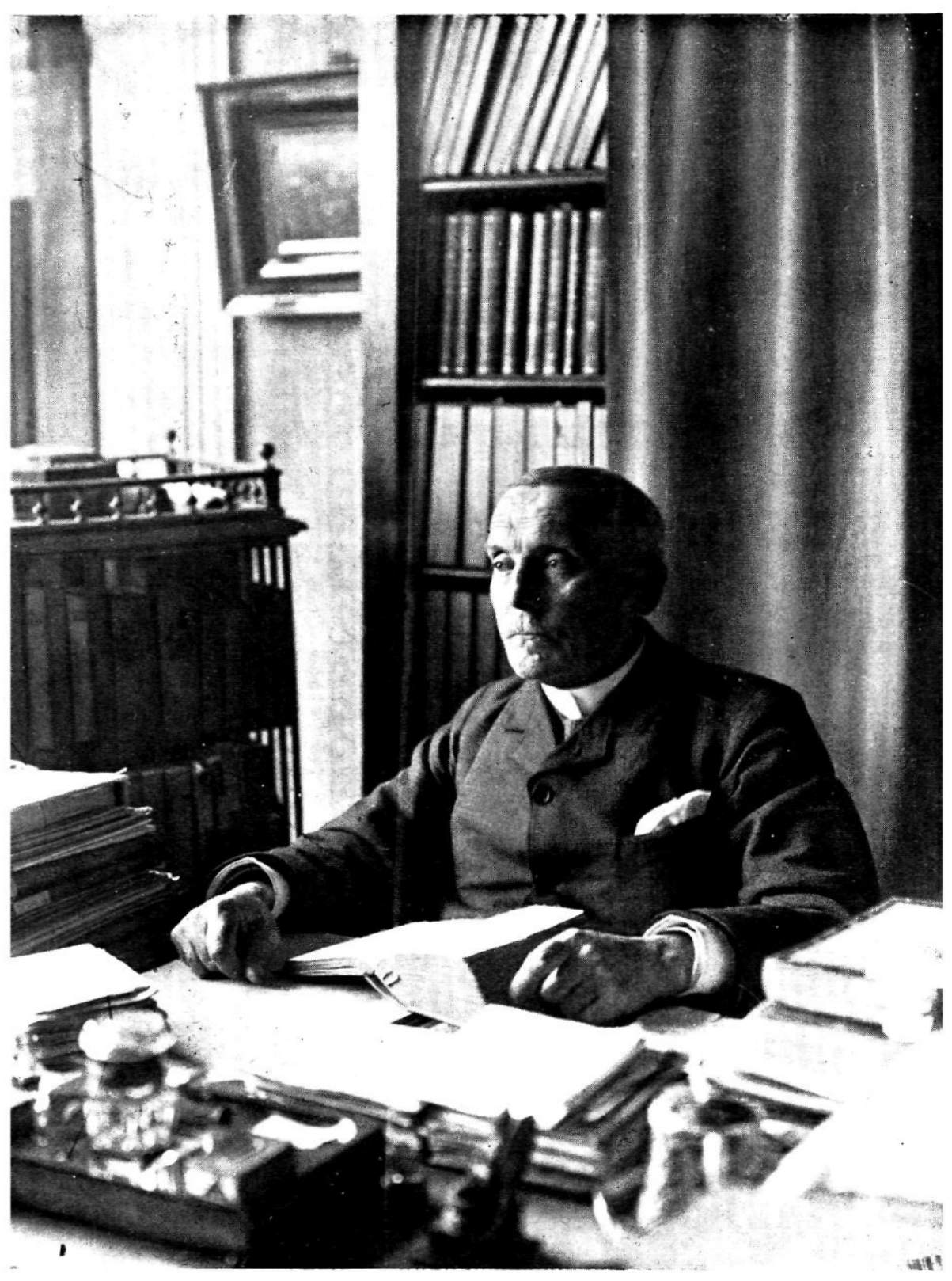

DR. G. P. ROUFFAER,

op 65-jarigen leeftijd. 


\title{
HERDENKING VAN DR. G. P. ROUFFAER
}

\author{
DOOR
}

N. J. KROM.

Het Koninklijk Instituut voor de Taal-, Land- en Volkenkunde van Nederlandsch-Indië is aan Gerret Pieter Rouffaer veel verschuldigd, gelijk ook hij zijnerzijds veel te danken had aan het Koninklijk Instituut. Het spreekt dan ook wel vanzelf, dat toen de dood aan dien band een einde had gemaakt, het Instituuts-bestuur eenstemmig van oordeel was, dat in één der eerstverschijnende afleveringen van de Bijdragen een herdenking zou moeten doen blijken, wat de overledene voor de Indische wetenschap en voor het Instituut had beteekend. Het Instituut voelde dat als een behoefte, maar niet minder als een plicht.

Het kon er tevens van overtuigd zijn, met zulk een herdenking geheel in Rouffaer's geest te handelen. Toen deze zich in 1909 zette aan de taak om van het leven van den door hem zoo hoog geschatten Brandes de goede herinnering vast te leggen, heeft hij het uitgesproken, het een voorrecht te achten op deze wijze aan den drang van dankbaarheid over dit leven en dit werk gevolg te mogen geven. En eenige jaren later gaf de dood van Charles te Mechelen hem de gaarne aangegrepen aanleiding tot een huldiging, waarin men ontroering en genegenheid voelt natrillen.

Minder voor de hand lag het, op welke wijze een herdenking haar vasten vorm zou moeten krijgen. De eigenaardigheid en veelzijdigheid van Rouffaer's bemoeienissen makten, dat niemand zich bevoegd kon achten om zijn werkzaamheden in haar geheel te overzien. $\mathrm{Er}$ is dan ook over gedacht, aan een aantal personen te verzoeken, ieder een onderdeel voor zijn rekening te nemen, doch ten slotte achtte men het bezwaar van het gemis aan eenheid bij een in losse stukken uiteenvallende levensbeschrijving grooter dan het voordeel der te bereiken betrekkelijke volledigheid.

Bij het aanvaarden van zijn taak stelt schrijver dezes het dan ook D1. 84. 
op prijs te verklaren, dat hij geenszins de illusie koestert, de figuur van Rouffaer algeheel tot haar recht te kunnen doen komen. Onze persoonlijke relatie is eerst aangevangen in 1908, toen Rouffaer reeds tegen de vijftig liep, en daarbij een man van beteekenis was, schrijver van een belangrijk aantal gezaghebbende artikelen en met een algemeen erkende positie in de Indische wetenschap. Alles wat daarvoor ligt, hebben wij noodzakelijkerwijze uit de tweede hand. Intusschen heeft latere nauwe samenwerking op een terrein, waar ook volgens hemzelf het door hem bereikte van verre strekking is geweest, gelegenheid gegeven om ook uit de voorafgegane jaren eenige bijzonderheden uit zijn eigen mond te vernemen.

Ieder, die Rouffaer gekend heeft, weet dat het hier, zoo ergens, onmogelijk zou zijn den persoon te scheiden van het werk; zijn geheele wijze van denken, handelen en spreken weerspiegelt zich rechtstreeks in zijn geschriften. In hun ontstaan worden ze verklaard door kennis van het karakter en den aanleg van den auteur, en omgekeerd leveren ze kostbare bouwstoffen om het beeld van diens persoonlijkheid uit op te trekken. Het is dan ook vooral uit de geschriften, dat wij zullen trachten iets vast te leggen van Rouffaer's beteekenis. Zijn uiterlijke levensomstandigheden bieden daartoe in hun ambteloos verloop al heel weinig aanknoopingspunten; zij geven eerder aanleiding tot de verwonderde vraag, hoe iemand zonder eenigen ambtelijken invloed of maatschappelijke positie zulk een belangrijke figuur voor Indië heeft kunnen worden.

Het is weder Rouffaer zelf, die ons aanwijst, op welke manier naar zijn wensch de levensbeschrijver het werk moet aanvangen, en wat hij in de eerste plaats van noode heeft: vrijmoedigheid en evenwicht van oordeel. „Evenwicht van oordeel” - zoo schrijft hij in de reeds geciteerde Herdenking van Brandes — , ,gelijk zoo uiterst noodig is waar men één persoon-alleen beschouwt, en al te licht dus vervalt in het vergeten van anderen. Vrijmoedigheid ook, zooals van man tot man betaamt, en zooals hijzelve niet anders gewenscht kan hebben." Naast die beide noemt hij dan nog een derde vereischte: ,dat warme menschelijke gevoel, dat nog beter is dan alle geleerdheid". In dit laatste opzicht althans weet schrijver dezes tegenover Rouffaer niet te kort te schieten. Moge het evenmin in de beide andere eigenschappen het geval zijn.

Boven aangegeven redenen hebben ons voor het grootste deel van Rouffaer's levensloop afhankelijk doen zijn van gegevens van anderen. Velen hebben met groote gulheid medegedeeld wat zij 
wisten; zij zullen niet verwachten hier met name genoemd te worden, doch mogen overtuigd blijven van onzen dank voor hetgeen zij op zeer verschillend gebied hebben bijgedragen. Twee personen echter zou het onmogelijk zijn niet afzonderlijk te vermelden, aangezien zonder hun hulp dit levensbericht niet tot stand ware gekomen: dr. J. W. IJzerman en den heer W. C. Muller, van wiens hand ook de hierachter opgenomen bibliographie is. Beiden zullen in het hier volgende dikwijls hun mededeelingen herkennen, zonder dat telkens van de ontleening wordt melding gemaakt; de lezer zij eens en vooral op de hoogte gebracht, dat het feitenmateriaal, voorzoover niet op Rouffaer's eigen geschriften of nagelaten aanteekeningen berustend, in hoofdzaak van beide genoemde heeren afkomstig is.

Wanneer men den loop van Rouffaer's leven overziet - en het heeft zijn nut daarmede aan te vangen, juist omdat het niet de duidelijke insnijdingen van een groote maatschappelijke of wetenschappelijke carrière vertoont - dan blijkt zijn bemoeienis met Indië daaraan de groote lijn te hebben gegeven. $\mathrm{Na}$ zijn jongensjaren, zijn ingenieursstudie en een paar voor zijn vorming belangrijke reizen naar Italië, vertrekt hij op 25-jarigen leeftijd in 1885 naar Indië; hij vertoeft daar vijf jaar, werkt er hard, en legt er den grondslag voor zijn geheele latere wetenschappelijke werkzaamheid. Dat blijkt intusschen nog niet dadelijk na zijn terugkeer in Europa in 1890; integendeel schijnt hij eerst, vooral tengevolge van een verblijf om gezondheidsredenen in Spanje, een eenigszins andere richting uit te gaan. Eerst in 1898, wanneer het Instituut hem als adjunct-secretaris aan zich verbindt, gaat hij zich met volle kracht op de Indische studie werpen en begint een reeks van verbazingwekkende publicaties, welke een tiental jaren aanhoudt. De voorbereiding van een tweede Indische reis brengt dan een onderbreking zoowel van zijn auteurswerkzaamheid als van zijn betrekking tot het Instituut; de reis zelve heeft van 1909 tot 1911 plaats : hij verzamelt er veel nieuw materiaal, doch keert met een geknakte gezondheid terug. Na min of meer hersteld te zijn, komt hij er niet meer toe de resultaten van de reis in het voorgenomen groote werk neer te leggen, doch wel begint in 1913 een nieuwe reeks geschriften, die hoewel onder steeds moeielijker omstandigheden tot stand gebracht, tot het laatst toe dezelfde uitnemende kwaliteiten blijven vertoonen. Na 1920 verminderen de krachten; zoolang hij kan, blijft hij met tusschenpoozen werkzaam, maar ten slotte moet de geest zich gewonnen geven en komt na duistere en droevige maanden de dood als een bevrijding. 
van nature weinig geneigd maakten om zulke als ,onecht” gevoelde kunst te waardeeren.

Met een groot deel der toenmalige studenten is hij, dat ligt eigenlijk ook voor de hand, onder den invloed geraakt van de Multatulivereering, die in deze jaren al onze universiteiten en hoogescholen had aangestoken. Wellicht heeft dit het eerst zijn belangstelling voor Indië gaande gemaakt, al bleef het dan voorloopig ook nog een belangstelling uit de verte. Eerst later zou blijken, dat de gedachten van Multatuli toch meer vat op hem hadden gekregen dan op zijn meeste tijdgenooten, en clat hij er behoefte aan had, daaromtrent met zich zelf tot klaarheid te komen.

Voorloopig waren twee andere zaken voor den student Rouffaer van veel grooter en onmiddellijker gewicht. De eerste is een teleurstelling op moreel gebied, naar wier omstandigheden zich slechts laat gissen, maar die hem zwaar moet hebben getroffen en die veel van zijn energie heeft geëischt om er zich bij neer te leggen; later is hij de Delftsche jaren als zijn ,,zwarten tijd" blijven beschouwen. De tweede is het groeiend besef, dat er wat meer en wat beters in hem stak dan een mijningenieur, namelijk een dichter.

Wij mogen het oudste der door hem zelf bewaarde gedichten hier wel een plaats geven. Het is gedateerd 24 Mei 1879, te Delft, en heet

\section{LENTELIED.}

't Lenteluchtje,

't Lentezuchtje

Van het weelderige Zuid,

Drijft der toppen

Groene knoppen

Van de lindeboomen uit.

't Al zich koestert,

't Al verbloesemt

In den teedren zonneglans,

Schooner pralend,

Warmer stralend

Aan den helderblauwen trans.

En de koren

$\mathrm{Zijn}$ herboren

Van het dartel vooglenheir,

Zinbetoovrend,

Hartverovrend

In hun blijden jubelkeer. 
't Kleine spruitje,

Door het Zuidje

Met een luwe lucht omgeurd,

Heeft het kopje

Uit het knopje

Reeds vrijmoedig opgebeurd.

Heel der aarde

Bloemengaarde,

Door de Zefier zacht omzweefd,

In de zwoelte

Van de koelte

Met één tooverslag herleeft.

Juich dan, harte,

$\mathrm{Nu}$ geen smarte,

$\mathrm{Nu}$ geen ijdel treuren meer !

Dat de aarde,

De herbaarde,

U eens nieuwe liefde leer' !

Van denzelfden datum is nog een meer persoonlijk en lyrisch vers, ,Op het mondje van ....”, en een week later volgt een Avondlied. Deze gedichten zijn overgeleverd zóó, als de auteur ze zeven jaar later nog eens heeft overgeschreven en herzien, en ook dan nog blijkt, hoe moeizaam ze tot stand kwamen, met toevoegingen, doorhalingen en telkens weer afgekeurde nieuwe pogingen om de weerbarstige woorden en maten tot zijn wil te dwingen. Ziedaar dan tevens een karaktertrek van Rouffaer in zijn wetenschappelijk werk: nooit tevreden met den vorm, waarin hij zijn denkbeelden wereldkundig maakte, maar steeds vijlende, wijzigende, toevoegende, tot het allerlaatste moment, en tot wanhoop van den zetter.

Intusschen werd de studie ondanks alles niet verwaarloosd, en in ongeveer denzelfden tijd, waarin de gedichten werden geschreven, werd ook het eerste examen met goed gevolg afgelegd. Maar nog een andere gebeurtenis had in 1879 plaats, van gewichtigen invloed op Rouffaer's verder leven : het overlijden, in het voorjaar, van zijn diepbetreurde moeder. De leegte, die dit verlies veroorzaakte, de betrekkelijke onafhankelijkheid, die er het gevolg van was, het onbevredigende van de studie als zoodanig, deden het besluit rijpen om aan zijn leven een andere richting te geven. Het feit, dat het afgelegde examen had getoond, dat de afbreking der studie niet uit onvermogen geschiedde, kan er ook toe meegewerkt hebben. Hoe 
het ook zij, Rouffaer zou niet meer naar Delft terugkeeren, doch kamers zoeken te Deventer.

Waarom daar en niet in zijn vaderstad Kampen ? Hij motiveert het zelf aldus, dat hij wel eens wat anders wil zien en niet altijd hetzelfde ,land van Kampen” voor zijn neus wil hebben. Voorts zijn de omstreken van Deventer oneindig mooier en vooral is er de herinnering aan het vroeger genotene te Twello. Maar bovenal was er de aandrang van de zijde van zijn geliefde oudste zuster Caroline, mevrouw Carolina Magdalena Leussen-Rouffaer, die acht jaar in leeftijd met hem verschilde, en die op dat oogenblik met haar echtgenoot op „Rustoord” te Diepenveen bij Deventer woonde. Haar wensch heeft den doorslag gegeven.

Het lijkt ons niet onmogelijk, dat op het oogenblik, dat het besluit genomen werd, het Rouffaer eigenlijk slechts vaag voor oogen stond, wat de nieuwe levensrichting zou zijn; en dat hem meer de negatieve kant van het geval, niet meer voor ingenieur studeeren, dan de positieve duidelijk was. Toen echter het plan tot uitvoering kwam, was alle onzekerheid verdwenen, want in dien tusschentijd, in het najaar van 1879, had de reis naar Italie plaats gevonden, welke voor hem een openbaring werd.

Zwitserland kende hij reeds. $\mathrm{Nu}$ trok hij, geheel alleen, het beloofde land Italië binnen, Milaan, Genua, Pisa, Florence, Rome, Napels, Pompeji en als verste punt Paestum. Te Rome is hij in aanraking geweest met den kunstschilder Koelman, wiens stofhuishouden grooten indruk maakte. In Paestum schreef hij een merkwaardigen brief aan Tholen, merkwaardig niet alleen om den inhoud, maar ook reeds om het feit dat, gelijk uit het schrijven zelf blijkt, dit gedurende de heele reis de eenige brief was, dien hij met een vijf dagen later te Pompeji geschreven toevoegsel aan zijn besten vriend deed toekomen. Toch is op dat oogenblik Tholen, die juist vóór Rouffaer's vertrek het portret van diens moeder had voltooid, de eenige, tegenover wien hij zich wil en kan uitspreken: ,geloof mij”, zegt hij aan het slot, ,,dat ik zoo iets slechts aan jou schrijven kan en schrijven durf; het is mij een behoefte en tegelijk een genot het aan den eenigen waren vriend dien ik heb te kunnen onthullen, maar ook aan hem-alléén". Men ziet, hoe hij ook voor zijn eigen gevoel zich hier geheel geuit heeft, en wij niet een gelegenheids-briefschrijver, doch den echten Rouffaer van 1879 voor ons hebben.

Op 8 November van dat jaar dan schrijft hij van den grond van 
een der Paestumsche tempels over zijn reis, of liever over het laatste deel daarvan.

„In Pompeji ben ik een heele week geweest en heb daar meer dan genoten; en desniettegenstaande ga ik er van hier nog een dag of drie, vier naar toe, zoo prettig is er het. Van Pompeji heb ik ook den Vesuvius bestegen, maar wat ik daar genoten heb zal nooit uit mijn geheugen gaan. Ik heb daar boven bij den krater toch een heelen nacht wakende doorgebracht: hoe het echter was, alles stil en eenzaam om je heen, en daar voor je de rusteloos werkende vulkaan telkenmale met donderend geluid een rookkolom opwerpend, door den vuurgloed beneden als gesmolten lava lijkende, terwijl duizende groote en kleine roodgloeiende steenen door dienzelfden vulkaan worden omhoog geworpen $-\mathrm{o}$, dan voel je je zoo klein en nietig bij zulke natuurkrachten !....

„Wat ik hier geniet, kan ik je niet zeggen; ik heb heel Italië doorreisd en vreeselijk veel schoons gezien en toch ik kan je stellig verzekeren dat deze grieksche tempels hier het toppunt zijn van alles wat ik genoten heb. Vooral de eene, prachtig geconserveerd, is een verrukking; maar niet een, die eenmaal genoten, later het gezicht niet weder trekt, neen dit geeft mij, elken keer als ik er weer de blikken op richt, dezelfde bron van onuitputbaar genot. Dan zet ik me in den tempel neer, boven me de prachtige blauwe hemel van Italië (die werkelijk veel blauwer dan bij ons is), voor mij het landschap waarbij men aan den horizon de zee ziet tintelen en rondom het meer dan imposante, hoog verhevene van den tempel zelf $-\mathrm{ik}$ kan je zeggen, zoo heb ik uren reeds gesleten en doe het nog en verveel mij geen oogenblik. Het is of een deel der hooge ernst en tevens ware verheffing van den tempel, of een deel der gelukkige en schoone denkkracht der Oude Grieken op je neerdaalt en je onwillekeurige mijmering met een schoon waas omhult. Hoe dikwijls dacht ik dan wel niet, o had ik toch in dien verheven tijd geleefd! ,Maar God zij dank dat er nog betrekkelijk zooveel van hun denken en werken over is, dat we het toppunt van. schoonheid, het ideaal van schoonheid om zoo te zeggen bij hen vinden kunnen."

Pompeji, de Vesuvius, Paestum en dan deze beschouwingen over den adel der Grieksche kunst; wanneer men dat alles leest, voelt men de neiging Goethe's Italienische Reise nog eens op te slaan. En geeft men aan die neiging gehoor, dan zal men, zij het natuurlijk op geheel andere wijze, verwante gevoelens terugvinden.

Duidelijker nog spreekt de toevoeging, die op 13 November den 
brief uit Paestum komt aanvullen. „Want, $\mathrm{O}$, wat ik in mijn leven toch hoop, en als mijn financiën en tijd het maar eenigszins toelaten, ook zal zien, dat is Griekenland. Dien heiligen grond te betreden en te bestudeeren, dat is zoo te zeggen mijn voorloopig levensdoel. Maar eer doe ik dat niet voordat ik volkomen met het Grieksch en Latijn bekend ben, en dat duurt nog een jaar of drie, vier."

Een weerzien van Italië, naar hij hoopt tezamen met zijn vriend, behoort in elk geval tot de mogelijkheden, immers het leven is er goedkoop genoeg. Hij vertelt, van 5 lire daags te leven, en dat te Rome van 4, te Napels zelfs van 3 lire gedaan te hebben: hier herkennen wij weder een trek van den soberen Rouffaer der latere jaren. „Een reis in Italië”, zoo betuigt hij nogmaals, „kan de krachtigste uitwerking hebben, zoo ten minste op mij; wat het is, ik zou het niet in woorden kunnen brengen, maar dat het den levendigsten invloed op mij gehad heeft en nog heeft, en dat ik in een massa opzichten, denkwijzen, beschouwingen, en om kort te gaan in alles totaal veranderd ben, dat verzeker ik je." Het is de adem van het ideale leven, de bezieling met hooger adel, het aandeel in die weldadige en schoone wereldbeschouwing, die vooral en vooral de Grieken tot zooveel schoons, tot zooveel edels in staat stelde.

„Ik was het reeds in mijn hart, maar hier is het pleit voldongen: ik ben idealist, maar niet genoeg kan ik de onuitputtelijke genoegens noemen, die zulk een levensbeschouwing meebrengt, en je de realistische gebeurtenissen met een helderen glimlach doet beschouwen.

„En dan de natuur hier; o gelukskind, dat ik ben, die na de verhevene maar doode, de trotsche natuur van $Z$ witserland genoten en met zielsverrukking gezwelgd te hebben, mijn hart kan doen genieten en mijn fantasie laten werken bij de lachende, zich den verhevenen schoonen hemel huwende, dreven van Italië. O, hoe bekoorlijk, hoe lachend, hoe idealistisch schoon! Het is alsof men in Zwitserland de stemme hoort van Vondel in zijn hoogverheven Hemelkoren, in het andere hoort men de suizelende, weelderige liedekens van onzen eenigen, Italiaanschen Hooft. Het is alsof deze natuur mij beteren blik geeft in literatuur, of mijn gedachten zich uitbreiden, zich vormen, zich ronden, nu ik deze natuur gezien heb. Het is hier een eeuwig murmelend lentelied dat door den olijfhaag suizelt; een eeuwigschoon minnelied dat zich met den hemelgeur der oranjebloesem vermengt en zich in de wijngaardranken gevangen laat. Het is hier, en beter, warer, juister woord kan ik niet vinden - schoon! 
„O, beste, hier in Italië zwelt mij de borst van ongekend, onbestemd verlangen. $\mathrm{O}$, hoe zou $\mathrm{ik}$ wenschen een dichter te zijn en in de snaren te kumnen grijpen om er een smeltend minnelied aan te onttokkelen. God weet wat er mij weggelegd is; wellicht niets, wellicht veel. Maar al wordt er dan ook nooit iets uit mij, dan kan ik toch zeggen, dat zoo ik al niet de gewrochten van den dichter heb kunnen vervaardigen, ik dan toch evenveel zielsgenot en evenveel zielsverheffing gekend heb als hij."

Ziehier dus het nieuwe ideaal: een dichterschap, voortkomend uit en gedragen door de schoone levensbeschouwing der klassieke oudheid. Een eerste vereischte om dat te bereiken moest wel zijn, de oudheid goed te leeren kennen en daarmede was tevens de onmiddellijk voor de hand liggende taak gegeven: studie van Latijn en Grieksch. Met den vasten wil zich daarop toe te leggen, keert Rouffaer over Napels, Rome en Turijn, met een kort oponthoud bij een neef te Genève, naar het vaderland terug. Het was volstrekt niet zijn bedoeling, zich met de nieuwe studie een maatschappelijke positie te verwerven; het was hem uitsluitend om het volgen van eigen studiezin te doen.

Niet te Deventer zelf is hij ten slotte terecht gekomen, doch hij trok in bij zijn zuster en zwager op Rustoord te Diepenveen, en daar vinden wij hem dus in 1880 en volgende jaren, verdiept in de klassieken. Niet onafgebroken: juist omdat geen vaste cursus gevolgd behoefde te worden en geen examen in het vooruitzicht stond, was er telkens gelegenheid en aanleiding tot onderbreking, vooral om weder op reis te gaan, hetzij alleen, en dan dikwijls naar plaatsen, waar de musea Hollandsche meesters bevatten, hetzij in gezelschap zijner zuster, die hij tot tweemaal toe voor enkele maanden bij een ter wille harer gezondheid ondernomen verblijf in het buitenland vergezelde. Op die wijze heeft hij Duitschland, Frankrijk, Engeland, Italië en Spanje bezocht. Dat zulke onderbrekingen voor een vlot verloop der studie niet heel bevorderlijk waren, ligt voor de hand. Het is niet onmogelijk, dat ook een onbestemde vrees voor eigen gezondheid, in verband met het lot zijner ouders, hem tot het deelnemen aan deze reizen bracht. Uitgesproken heeft hij dat nooit, en misschien het nauwelijks zichzelf toegegeven, want hij was in dezen tijd een van die menschen, die er zich op laten voorstaan alles te kennen en alles te kunnen, ook lichamelijk.

Leermeesters in de klassieke talen waren dr. A. J. Kronenberg en drs. F. W. Fledderus. Bovenal echter genoot hij van de lessen van en 
den omgang met dr. A. J. Vitringa, den hoogstaanden en begaafden rector gymnasii, in wijder kringen bekend onder zijn nom de plume Jan Holland. Met dezen fijnen geest voelde Rouffaer verwantschap; hij heeft gewillig diens invloed ondergaan en is altijd dankbaar blijven erkennen, hoeveel hij aan Vitringa te danken had. Herhaaldelijk sprak hij zijn vereering uit voor deze hoogstaande persoonlijkheid.

Al zal Rouffaer stellig ook veel van Vitringa's inzichten inzake de klassieke cultuur hebben opgestoken, bovenal was de omgang met dezen geloovigen Katholiek van belang, omdat hij een tegenwicht gaf voor hetgeen de studententijd aan Multatuliaansche vrijdenkerij had opgeleverd. Trouwens wat dat aangaat moet ook de dagelijksche omgang met zijn zuster niet worden onderschat. Aan Vitringa ontleende Rouffaer ook stellig zijn groote belangstelling voor het Katholicisme, zich in het bijzonder uitend ten opzichte van de liturgie; een belangstelling, die later tijdens het verblijf in Spanje nog versterkt zou worden. De beide deelen van Gräser, Die Römisch-Katholische Liturgie (1829), vol aanteekeningen, werden door hem onder zijn grootste boekenschatten gerekend, waaromtrent hij dan ook een speciale beschikking heeft gemaakt.

Hoeveel goed nu ook de jaren op Rustoord aan Rouffaer gedaan mogen hebben, en met hoeveel dankbaarheid hij er later op terugzag, wat de eigenlijke studie aangaat zijn de resultaten niet heel bevredigend geweest. Wanneer wij constateeren, dat hij na die vijf jaar van het Latijn wel iets afwist, dan is daarmede zeker genoeg gezegd; verder dan het kunnen begrijpen van eenvoudige stukken is hij niet gekomen. Met het Grieksch zelfs zóóver niet; als hij later in de Encyclopaedie van Nederlandsch-Indië een nieuwe interpretatie meent te kunnen geven van een uitdrukking bij den geograaf Ptolemaeus, dan komt professor Kern hem vriendelijk op de vingers tikken ${ }^{1}$ ), zich bij zijn uitleg eenigszins verontschuldigend, omdat ieder die Gricksch kent het eigenlijk wel weet. Al heeft nu zijn latere werk Rouffaer ook steeds verder van de klassieke oudheid afgebracht, er kwam toch altijd weer iets van het oude enthousiasme boven, als het gesprek er op kwam; nog tijdens zijn laatste drukke werkperiode vond hij tijd zich te verdiepen in Pichon's Histoire de la littérature Latine, er van te genieten en er telkens opnieuw weder op terug te komen; groot was ook zijn ingenomenheid met Leopold's artikelen

1) In Bijdr. 7: IV (1905) p. 364. 
uit de Leerschool van de Spade in de Nieuwe Rotterd. Courant.

Wat de reizen aangaat, worden wij iets nauwkeuriger ingelicht, wanneer Rouffaer in de tweede helft van 1884, in Italië vertoevend, correspondenties schrijft in de Kamper Courant en in een van die artikelen (nummer van 28 Dec.) een overzicht geeft van herstellingsoorden in het Zuiden, die hij uit eigen aanschouwing kent. Montreux wordt geprezen, maar heeft te lijden van nevel en koude; aan de Riviera wordt Nice, onfrissche groote stad, afgekeurd, maar Mentone en San Remo zijn aanbevelenswaardig, Cannes met zijn vele wandelingen en het poëtische Bordighera nemen een eigen plaats in. Catania is vuil en onaangenaam, Málaga wel mooi en gezond, maar Spaansch en duur, Ajaccio eindelijk, vervelend en ongezond, heeft niets, althans nog niets, te beteekenen. Het aardige van dit stuk zijn de korte en scherpe karakteristieken der beschreven plaatsen.

Het bezoek aan Ajaccio moet blijkens een paar gedateerde gedichtjes eind October 1883 hebben plaats gevonden, volgend op een verblijf te Cagliari; onder die verzen is een Duinmijmering, die geheel naar het vaderland verplaatst: ook een eigenaardigheid van dezen dichter, die later in Indië den winterschen sneeuwval en den Siciliaanschen zonsopgang zal bezingen. Iets vroeger was een lang gekoesterde wensch in vervulling gegaan, door het feit dat hij van de schoonheden van Italië tezamen met zijn vriend Tholen kon genieten; deze logeerde een paar maanden bij Rouffaer te Rome en was er getuige van diens omgang met allerlei soorten van menschen en van zijn bijzondere aandacht voor den Roomsch-Katholieken eeredienst. Ook Capri en Napels bezochten de beide vrienden gezamenlijk. Op Capri vertoefde Rouffaer in 1883 vrij langdurig, want de gedichten reiken van 20 Mei tot 4 Augustus. Nergens vindt men iets, dat met de klassieken ook maar in een verwijderd verband staat. Is hij misschien ook voor zichzelf tot de conclusie gekomen, dat de studie der oudheid hem niet de levensvervulling zou schenken, die hij ervan gehoopt had ? Men mag het wellicht opmaken uit de stemming, waarin in Augustus 1884 een gedicht werd neergeschreven op Rustoord, in zijn oorspronkelijken vorm later is het weer gewijzigd - aldus aanvangend:

Huivrend ga ik ronde

In de doodenstad van mijn hart.

Dof weerklinkt de tred mijner heugenis

En roept sombere echo's 
Uit hol weerklinkenden bouwval.

Groenend rankt veil

Uit luchtpaleizen, die ' $k$ weleer schiep,

En streelt fluistrend de lokken

Van mij, vroegeren meester.

Hoewel aan het slot van het gedicht het donker vuur uit de oogen eener geliefde aan dien wanhoop een einde maakt, lijkt het niet ongerijmd, dat de gedroomde uitredding een fictie, maar de moedelooze stemming werkelijkheid was. Hoe het zij, aan het eind van dat jaar is Rouffaer opnieuw in Italië, en stelt er de zoo straks genoemde correspondenties voor de Kamper Courant op, welke reeks in de voorafgaande maand Juli met de beschrijving eener wandeling over de Via Appia, op een warmen middag te één uur aangevangen, was geopend. Een drietal artikelen zijn aan Camorra en Maffia gewijd. Van geheel anderen aard is „Een verfrissching in Napels' straten” (nummer van 2 Januari 1885), dat begint met: „Vijfhonderdduizend menschen, die in een roes van opgewondenheid en rusteloosheid leven, zonder iets te doen te hebben of ook maar iets uit te voeren: ziedaar Napels," en dan verder geestig en raak het Napolitaansche volk en het Napolitaansche leven in enkele trekken schetst, om te eindigen met den waterverkooper, die aan het artikel zijn titel verschafte. Het is alles goed naar het leven geobserveerd en weergegeven en vertoont in den vlotten journalistieken schrijftrant toch ook den scherpen opmerker Rouffaer der latere wetenschappelijke artikelen.

In een laatste stukje over een mislukt genie, een te Rome aangetroffen Russischen beeldhouwer, wordt ter inleiding iets verteld over de vroegere Hollandsche schilders, die Italiaansche kunst hebben voortgebracht. Inderdaad, ook daarvan was Rouffaer op de hoogte; de veelzijdigheid zijner belangstelling was allerminst iets van zijn latere jaren alleen. De Hollandsche schilderkunst heeft hem reeds vroeg aangetrokken, misschien ook wel door de omstandigheid, dat zijn vaderstad Kampen een belangrijke verzameling huisvestte, in het bezit van mevrouw de wed. mr. F. Lemker, wier echtgenoot burgemeester van Kampen was geweest, en die er in de BovenNieuwstraat woonde. Van deze collectie heeft Rouffaer gedurende zijn Deventer jaren een volledige beschrijving gemaakt. Waar dit handschrift gebleven is, weten wij niet - bij Rouffaer's nagelaten papieren was er in elk geval ook geen afschrift van —, doch iemand, 
die het wel gezien en geconsulteerd heeft, noemt het ${ }^{1}$ ) ,een gedetailleerde beschrijving, vol levendige, scherpe opmerkingen.” De collectie zelve is in 1908 na den dood der eigenares onder den hamer gekomen.

De voornaamste wetenschappelijke resultaten van zijn werken in deze verzameling en in de Kamper schilderijen in het algemeen zijn echter gepubliceerd, en wel na zijn vertrek naar Indië, in de jaargangen 1886 en 1887 van het tijdschrift Oud-Holland, onder den titel: Vier Kamper schilders, Ernst Maeler, Mechteld toe Boecop, Bernhard Vollenhove, Steven van Duyven. De auteur begint met een verontschuldiging: belangrijk nieuws op archiefgebied zal hij niet geven, want zijn data zijn aan gedrukte stukken en aan mededeelingen van archivarissen ontleend; hij zal zich bepalen tot wat de studie der schilderijen zelf hem leerde en wat dat aangaat is hij zeker belangrijk nieuws te kunnen brengen, zich daarbij gelukkig rekenend als geboren Kampenaar aan oud-Kamper schilders de eer te kunnen geven, die hun toekomt.

Als hij dan Ernst Maeler behandelt, eerst diens familienaam bespreekt, dan de vier bekende stukken van Maeler beschrijft, een vijfcle meesterwerk aan hem toeschrijft, nog een paar andere schilderijen naar analogie herkent en met een opsomming van data eindigt, dan geschiedt dat alles met dien logischen redeneertrant en dien overvloed van persoonlijke en andere bijzonderheden, elk nauwkeurig gedocumenteerd, welke ook den lateren Rouffaer in zoo hooge mate eigen zijn. Naar dezelfde methode wordt de eveneens in de zestiende eeuw werkzame Mechteld toe Boecop besproken, genealogie, personalia en werken; van den zeventiende-eeuwschen Bernard Vollenhove wordt de levensgeschiedenis uitgeplozen, terwijl dan naar de authentieke stukken een aantal andere ontwijfelbaar aan zijn hand worden toegeschreven. Eindelijk is diens tijdgenoot Steven van Duyven met zijn drie schilderijen een tot dusver geheel onbekende, helaas niet bijster belangwekkende, meester. Met deze ,uitputtende” behandeling van zijn vier sujetten doet Rouffaer zich als een kunsthistoricus kennen, van wien op het gebied der Nederlandsche schilderkunst goede diensten te verwachten waren.

Hij is op den ingeslagen weg niet voortgegaan en zelfs heeft hij. hoewel hij toch bemerkt moet hebben, hoe uitnemend hij voor dergelijk werk was toegerust en hoe verrassende uitkomsten hij kon bereiken, jaren achtereen in het geheel niets meer gepubliceerd. Een

1) In de Kamper Courant van 13 Januari 1928 (C. H. van Fenema). 
groote ommekeer in zijn leven was daar de oorzaak van, gevolg van het overlijden, op 3 April 1885, van zijn geliefde oudste zuster. Op het kerkhof te Diepenveen werd zij begraven, en in haar onmiddellijke nabijheid kocht Rouffaer zich zelve een graf. Hoe de slag hem trof, kan men vermoeden uit de mate van vereering, die hij haar toedroeg, een vereering die zijn stem van ontroering deed trillen, nog wanneer hij veertig jaar later dankbaar van deze liefde gewaagde. Haar welgelijkend portret keek steeds op hem neer; haar foto lag bij het aan haar gewijde groote dichtwerk, dat wij zoo straks zullen bespreken. Het best kan men wellicht zijn gevoelens opmaken uit de wijze, waarop hij die ruim een jaar na haar dood in Indië vertolkte.

$\mathrm{O}$, als ik $\mathrm{U}$ niet had, die waaktet op mijn paden, $\mathrm{O}$ zuster, die mij 't eerst mijzelven kennen deedt, Ik ging van doffe zorg en twijfelmoed beladen, Gekweld door eigen last, geknakt door eigen leed.

Nog zie ik 't blauwe oog zoo ernstig op mij rusten, Nog spreekt dezelfde mond mij vol van liefde toe, En doet mij zonder smart in 't oogenblik berusten, Toen eens het leven vlood, het veege lichaam moe.

$O$, 't aardsche leven slechts is leefbaar als wij trachten

De stem der innigheid in 't harte na te gaan!

Geen weifelende stap is dáár meer te verwachten, Waar ons de liefde steeds in volheid voor wil gaan!

Als iets van liefde of hoop mij door natuur gegeven, Tot steun van land en volk ooit van mij uit mag gaan, De moed daartoe, mijn kind, waar' nooit door mij verkregen, Hadt gij mij niet geschraagd bij 't moeilijk verdergaan.

Gij, heilig, heilig dan mijn aangevangen streven, Toon moedig mij den weg en 't ingeslagen pad;

Wat ons aan ziel, verstand en wilskracht werd gegeven, Gij toondet, hoe het slechts voor andren waarde had !

Het leed, dat hem door dit verlies had getroffen, het noodzakelijk einde van zijn verblijf op Rustoord, de onbevredigende uitslag van de klassieke studiën, het verlangen naar een nieuwe omgeving en nieuwe indrukken, zijn groote reislust, het zal alles wel hebben samengewerkt tot het besluit om ver weg te trekken, naar Indië. Waarom juist Indië ? Het is ons niet bekend, want hij had er geen 
familie, maar voor een reiziger als Rouffaer, tevens goed Nederlander, moest het aantrekkelijk zijn Indië uit eigen aanschouwing te leeren kennen en wellicht waren daarbij de herinneringen aan Multatuli krachtig genoeg om hem een meer dan gewone belangstelling te geven voor het land en het volk, welks lot hij bij het lezen van den Havelaar en van de Ideeën zoo dikwijls had moeten beklagen. Wij zullen zien, dat diezelfde Muitatuli-vereering later ook nawerkte in zijn begeerte, om op Java zich bepaaldelijk van allerlei agrarische verhoudingen op de hoogte te stellen.

Hoe het ook zij, de voorbereidingen waren spoedig afgedaan, en op 28 Juli 1885 vertrok Rouffaer van Rotterdam met het zeilschip Voorlichter. De reis duurde natuurlijk lang; hij heeft die o.a. gekort door het in het net schrijven van zijn vroegere gedichten, waaraan spoedig vele nieuwe zouden worden toegevoegd. Hij had den wensch uitgesproken een zwaren storm mee te maken, en die wensch ging inderdaad in vervulling: de Voorlichter heeft in ernstig gevaar verkeerd. Zoo begint dan in het najaar van 1885 Rouffaer's eerste Indische periode.

II.

Met welke voornemens is hij op 5 November 1885 te Batavia aan wal gestapt ? Niet met de vooropgezette bedoeling, dat blijkt uit alles, van een bepaalde studie in een nauwkeurig afgebakende richting. Hij kwam, zoo als hij zelf zegt, „om een zuivere plezier-reis van een maand of acht over Java en ten deele de Buitenbezittingen te maken," als belangstellende dus, mits men dat maar niet opvat als een gewoon belangstellende. Want zijn ijver en zijn leergierigheid waren buitengewoon, en hij is van den eersten dag af met waren hartstocht aan het informeeren, aan het studeeren en vooral aan het zelf rondkijken gegaan.

Een bewaard gebleven opschrijfboekje, waarin hij met zijn gewone nauwkeurigheid zijn uitgaven noteerde - de allereerste is voor den aankoop van een sarong - stelt ons in staat zijn eerste schreden te volgen, van het oogenblik dat hij zich van den Kleinen Boom naar het Hôtel des Indes laat rijden. Wij zien hem zijn haar laten knippen bij den Franschen coiffeur, zich in de kleeren steken (daarbij zijn ook een paar bergschoenen) en zich een fleschje inkt en een exemplaar van De Vries en te Winkel aanschaffen. Belangrijker intusschen zijn de eerste indrukken van Batavia, en wat hij daarvan noteerde, nemen wij hier over.

D1. 84 . 
„Rondgaand Chineesch barbier; klontong; knippen op straat; ophaalbruggen; schuiten net als onze pramen; chin. jonken (de kleine) herinnerend aan de Port. vaartuigen vooral aan de karveelen (caravellos) van Columbus; kleine paardjes voor Napolitaanschachtige sadò's; versiering en afsluitend venster-traliewerk bepaald Moorsch, gelijk in Toledo; geheel Napels-achtig met de inlanders als stoffeering dat wel veelkletrige vlinders lijken; heerlijk gebouwde, frissche kantoren; hôtels zooals te Pompei en te Capri; schippers ook hun pramen ,boomen”; geestig soort toppi's, wit of gekleurd baadje, stuk sarong met leeren gordel; kleurige, witte of zwarte broek; de ,,jongens" allemaal een hoofddoek; wajang orang; opiumkit; inlandsche kast; lichtjes 's avonds der pikoelers; zoo goed als geheel Europ. kleeding; de ,soudenier" Jan Pietersz. Coen, de „,vloo" van Waterloo; werkelijk de Holl. frisch op hun lichaam hier; Diergaarde; Museum(?) v. h. Bat. Gen.; logementleven; inlanders geen schoenen mogen dragen, Chin. meestal soort volle pantoffels; sadò's, kahar's en grobaq's, en hun publiek; goede en flink rijdende N. I. tram; aardige Capri-achtige bouwwijze; alleen nachtbroek en kabaai, benevens sloffen (eerste moeilijkheid voor een ,baar”) blijven in eere en zullen dat steeds blijven; koffiehuizen schijnen steeds dood geboren; voortdurend badenden in de rivier, vrouwen met den sarong boven de borsten, mannen met een doek om de lenden; vrouwen (en trouwens mannen ook) „chic” loopen, vooral aardig met pajongs; kinderen aardig met hun dikke buikjes; volkomen vrijheid van kostuum: de eene jongen loopt met zijn billen geheel bloot en een kort wit buisje, de ander met zijn naakten rug en een dun broekje; mooi van lichaamsvormen, vooral, vooral de mannen, en daaronder ook prachtige koppen; de vrouwen wat bouw betreft, vooral hun borsten (à la Venus van Milo) prachtig; er zou wat te vinden wezen voor een beeldhouwer en voor een genreschilder; echt Napol.; geliefde roode kalkkleur om muren enz. mee te dekken; bedelaars; frissche ,flesschen” op het ,huiske”, in 't Mal. (zeer typisch voor de fijne termen onzer voorvaderen) ,kakkoes” genaamd!; jongens beter dan Verschuur ze vond; inl. en Europ. soldaten; inl. behoorlijk, evenals de rijtuigen, uit den weg gaan voor Europ., en lang niet zoo onbeleefd als men ze wel schilderen wilde; het bed voor de muskieten uitwaaien; gewone Amst. muskieten; oud-Chineesch kerkhof; sarong-lucht, kampong-lucht en vulkanische lucht; Chin. bouw, ornamentiek en veelkleurigheid; Chin. soeprestaurateur met vermicelli en cappelletti (rabioli); petroleum- 
kannen voor waterdragers; aardige manier van gieten; bamboehuizen in de kampongs van halfbloed-families; gardoe's; bloeiende boomen; Chin. pandhuis; kikkers en krekels; wèl zingende vogels; wèl geurende bloemen; commensalen-huizen; ochtend- en nachtschot; de kracht van ,,verrek!'; Harmonie en Concordia; oud-Holl. huizen in de benedenstad, om en bij Jacatra-weg; bamboezen rustbankjes buiten ter zij van het huis, evenals bij onze oude huizen in steen; Chineezen overal in kantoren, bureaux enz., vooral voor geldtellen; Jan Compagnie; Batavia een soort Napels, maar driemaal kleuriger en, goddlank!, driemaal minder lawaai; opstootjes, uitjouwen, straatjongens zijn er niet; de huizen hier werkelijk „palazzi”; de Chineezen wèl levenmakers; luifels ; kongsi's; kamers in 't hôtel den heelen nacht geopend, toch wordt er niets gestolen, hoe zou dat bij ons zijn?; militair hospitaal; Onrust (oud kerkhof van na 1700), met afgebroken oud fort, Kerkhof met mooi geboomte en oud fort, Purmerend met warmoezerij en oud fort, Kuipertje kolenstation; ,prauwen” eigenlijk pramen met bamboezen achterdek; loodsen aan beide zijden der Groote Rivier; oud-holl. diakoniegesticht; Kampong Baroe: Bacherachs-gracht tot Tangeran toe, oud-Holl. buitenplaatsen door Chin. of Arabieren bewoond, oudHoll. watertrapjes met Delftsche tegels, zuid-holl. kakhuis, ,vaart” echt op z'n vaderlandsch; wij onze theetuinen van de Chin. overgenomen; nergens (behalve tegels) oud-Delftsch, wel oud-Chin. en oud-Jap. porselein; oud gebouw firma Moorman, Groote Rivier, met opkamers, enz. van 1685; sirih-bladen; kanarievogels; oudHoll. valsluizen ; bamboerustbankjes."

Deze gecomprimeerde indrukken van Batavia, die stof voor een heele beschrijving konden leveren, zijn aardig om het beeld van de stad en haar bevolking, dat zij geven, maar niet minder leerzaam voor de kennis van den persoon des schrijvers, om den aard van hetgeen hem trof en de wijze, waarop hij reageerde. Ze worden nog aangevuld door aanteekeningen over eenige opschriften en oude gebouwen, en de opmerking, hoe weinig er van invloed der Hollanders op Indië blijkt.

Gedurende November was Rouffaer te Batavia. Behalve het uitstapje naar Onrust enz. is hij ook al gauw naar Buitenzorg getogen, voorloopig nog maar kort, ter orienteering, later rustiger, en is hij ook wat verder de Preanger ingeweest; Tjiandjoer en Bandoeng werden achtereenvolgens bezocht, ook Tjitjalengka en Tjibadak, terwijl eerstgenoemde dezer beide plaatsen als uitgangspunt voor 
Tjilěmoes dient, laatstgenoemde voor Sinagar en Argalingga; de terugreis gaat over Soekaboemi. De keuze dezer plaatsen zal wel samenhangen met personen, die hij had ontmoet, of voor wie hij introducties had.

En dan komt ook de tijd voor meer gedegen studie, blijkende uit den aankoop van de daarvoor benoodigde boeken: een Regeeringsalmanak, De Louter's Staats- en administratief recht, en Van den Berg's Debet of Credit. Ook een eerste offer aan de kunst mogen wij als zoodanig vermelden, in den vorm van het koopen van eenige oud-porceleinen borden, een gĕndi en een pul. Op de bibliotheek van het Bataviaasch Genootschap werd hij wegwijs gemaakt door dr. J. L. A. Brandes, den ruim een jaar te voren uitgekomen taalgeleerde, met wien hij sedert in correspondentie bleef.

Al heel spoedig na zijn aankomst heeft hij gevoeld, dat de plezierreis iets anders zou worden, en het voornemen om na terugkeer naar Nederland in 1886 de studie over de Hollandsche schilderschool voort te zetten niet zou worden uitgevoerd. Toen hij aan wal stapte was, naar hij zelf zegt ${ }^{1}$ ), de koloniale politiek hem geheel vreemd; ,alleen zat mij, als goed Nederlander, de Havelaar-zaak dwars in den maag, doch had ik mij door Prof. Pierson's Koloniale Politiek tweemalen te lezen overtuigd gemeend van de doeltreffendheid der zege die de liberale beginselen sedert 1848 ook in onze overzeesche bezittingen meer en meer voldongen hadden." Intusschen reeds na de eerste dagen ,begon als een schrikwekkend spook de heerschende ontevredenheid op te rijzen van het geheele Bataviasche publiek. Waar men was, waar men kwam, waar men ging, om 't even, alle stemmen getuigden van mismoedigheid, antipathie, ergernis over Nederland en diens koloniaal beheer; een geheele toonladder van dreigende geruchten. Ik voelde mij Prof. Pierson's Koloniale Politiek ontzinken. En geenszins beter werd ik te moede toen ik van Batavia een uitstapje ging maken om de Preanger vluchtig te bezoeken. Hier waren het de planters welke steen en been klaagden over het regiment dat Nederland op Java had ingevoerd en in stand hield. Het „Indisch gemopper”, gelijk men het in Holland belieft te noemen, omgaf mij als een zwoele, onheilzwangere atmosfeer."

Die ondervinding doet vanzelf twee vragen bij hem rijzen: „Wat zijn toch de hoofdoorzaken der ontevreden stemming, die ik bij alle

1) De volgende bijzonderheden zijn ontleend aan het hieronder te bespreken boek over Multatuli. 
Nederlanders hier in Indië waarneem?” en „Is daar niets aan te doen?" Het opdoemen dezer vragen is het naderen tot een keerpunt : de plezierreis mocht geen plezierreis blijven, en er was belangrijker werk dan de Hollandsche schilderschool. Een nieuwe, zelf opgelegde taak wordt aangevangen, met als eerste vereischte een zich rekenschap geven van al het waargenomene, door een zoo uitgebreid mogelijke informatie.

Wat den inhoud zijner studie betreft, heeft Rouffaer het ons gemakkelijk gemaakt door het aanleggen van een verzameling Indische Aanteekeningen, een kleine 900 octavo papiertjes, waarop hij alles neerschreef wat hem belangrijk voorkwam bij lectuur en gesprekken. Hij is daarmede in Februari 1886 begonnen, te Indramajoe, maar heeft toen ook allerlei uit de voorafgaande maanden geboekstaafd; de aanteekeningen zijn vooral voor de eerste jaren zeer volledig, en loopen door tot Maart 1888. Wat dadelijk opvalt is, dat zij volstrekt niet uitsluitend op Indische zaken betrekking hebben, doch er ook allerlei over vaderlandsche aangelegenheden onder gemengd is, en voorts, dat de meeste aandacht valt niet, zooals men van den lateren Rouffaer zou verwachten, op kunst en geschiedenis, doch op staathuishoudkunde en staatsbestel.

De lectuur blijkt al dadelijk van den meest verscheiden aard. Kranten, brochures en boeken, in bonte verscheidenheid; de Verhandelingen van het Bataviaasch Genootschap en de Java Government Gazette, het Plakaatboek en De Jonge's Opkomst, de Spectator en de Gids, het Nederlandsch Tuinbouwblad en het Bataviaasch Nieuwsblad, de Kamerverslagen en het rapport der Kamer van Koophandel te Calcutta, het Staatsblad en de Nieuwe Financier, het Reglement op de particuliere landerijen bewesten de Tjimanoek en het Archief voor de geschiedenis der zending, de Latijnsche comedie en de Mededeelingen van het Ned. Zendelinggenootschap, de Heraut en de Katholieke Illustratie, het Wageningsch Weekblad en de Gereformeerde Geloofsbelijdenis, ze leveren allen hun bijdragen, en nu hebben wij ons nog maar beperkt tot de eerste twaalf bladzijden, en de losse opmerkingen buiten rekening gelaten, die ook alweer loopen van de traktementen der luitenants tot de temperatuur op Buitenzorg. Men kan zich zoo een denkbeeld vormen van de veelzijdigheid van den inhoud. Niet het minst belangrijk en niet het minst vermakelijk zijn de talrijke personalia.

Aan een aantal geschriften zijn lange citaten of overzichten ontleend, en het loont de moeite na te gaan, welke dat zijn, omdat ze 
ons de onderwerpen doen kennen, die Rouffaer gedurende zijn eerste Indische maanden het meest de aandacht waard schenen om er zich in te verdiepen. Het zijn vooreerst eenige stukken over Sprenger van Eijk, den toenmaligen (niet door Rouffaer bewonderden) minister van Koloniën, en voorts Van Delden, Blik op het Indisch staatsbestuur; Pruijs van der Hoeven, Mijne ervaring van Atjeh; Boissevain, Gewone en buitengewone uitgaven; Snouck Hurgronje, De beteekenis van den Islām voor zijne belijders; Sollewijn Gelpke, Ontwerp van eene landrente-ordonnantie; Stammer, Jahresbericht Zuckerfabrikation en de Liste générale des fabriques de sucre etc. Ook Valentijn heeft nog al wat stof geleverd; maar vooral is er heel veel op allerlei gebied ontleend aan het groote werk Java van P. J. Veth.

Behalve uit de boeken haalde Rouffaer zijn informaties echter ook gaarne uit de levende bron. Het begint in December 1885 te Buitenzorg; men vindt dan van tijd tot tijd tusschen de andere aanteekeningen ,,verhaal (van)...." met een naam, en dan hetgeen de persoon in kwestie heeft medegedeeld. Daarbij is allerlei, dat zoo uit het gewone gesprek is opgeteekend en zeker niet bestemd was iets anders te zijn dan verba volantia; men krijgt den indruk, dat de geinterviewden niet het flauwste vermoeden zullen hebben gehad dat hun vertelsels - somtijds naderen ze wel eens het kletstafelniveau - na afloop schriftelijk zouden worden vastgelegd, en dat zij, hadden zij dat geweten, danig geschrokken zouden zijn voor de gevolgen van een mogelijke indiscretie. Het voordeel is natuurlijk, zoowel voor Rouffaer indertijd als voor wie er thans kennis van neemt, dat men werkelijke meeningen voor zich krijgt, niet de voor publicatie pasklaar gemaakte lezingen, die de slachtoffers anders aan hun positie of reputatie verplicht zouden zijn geweest. Het spreekt overigens vanzelf, dat er onder deze verhalen ook veel van geheel neutralen en zakelijken aard zijn.

Een der eersten, van wie een ,,verhaal” is opgeteekend, is de man, die spoedig Rouffaer's groote vriend zou worden, de ingenieur Retgers. Het gaat over geologische opnamen en over den persoon van zeker onbekwaam chemicus. Er boven staat op de gewone manier: „Verhaal Retgers, mijningenieur, Buitenzorg.” Eerst later zijn de voorletters J. W. toegevoegd. Merkwaardig is ook de kwalificatie, die van Retgers gegeven wordt: „Ambtenaar voor niets zoo bang als voor den G. G. en voor.... de pers!" Die woorden zijn, klaarblijkelijk toen Retgers Rouffaer's vriend was geworden, weer 
doorgehaald. De vriendschap moet zich snel hebben ontwikkeld, want reeds na een half jaar wordt aan Retgers als vriend een gedicht opgedragen.

Ook de overige zegslieden worden goed gekozen: de secretaris van den Raad van Indië spreekt over het gebrek aan rijkdom in Indië, een ingenieur over bruggenbouw, een zeeof ficier over het begrooten van scheepsreparaties, de bekende K. F. Holle, bij wien Rouffaer te Waspada een drietal dagen logeerde, over landbouw en nijverheid en nog veel meer, de zoon van den Gouverneur-Generaal over binnenlandsch bestuur en opiumdelicten, de prins van Asjanti over de regeering van Van Twist, nog een ingenieur over Atjèhsche zaken en over de afwatering van de Tjiliwoeng, de procureur-generaal bij het Hooggerechtshof over de in Indië heerschende ontevredenheid in zake de Nederlandsche koloniale politiek, een veefokker uit het binnenland over allerlei grieven en over inlandsche zaken. Men ziet, hoe Rouffaer zijn tijd besteedt en hoe hij wordt ingelicht.

In het begin van het nieuwe jaar keert hij voor een enkelen dag naar Batavia terug om dadelijk daarop scheep te gaan $-\mathrm{mr}$. N. P. van den Berg was er zijn mede-passagier - naar Tjirěbon. Hij maakt een uitstapje naar Koeningan, en heeft ook eenig oponthoud om zich voor zijn oogen onder geneeskundige behandeling te stellen. Half Februari begint hij te Indramajoe, zooals wij zagen, zijn Aanteekeningen. Hij besluit er, zijn reis met een jaar te verlengen en spreekt er zoowel met een zendeling als met een rijsthandelaar, die hem over de padi inlicht; in Maart is hij te Tjirěbon terug, en ook de volgende maand blijkt hij daar te vertoeven. Op die plaats, een der meest antiek geblevene van Java, is hij sterk onder den indruk der omgeving geraakt en is er zelfs toe gekomen om op het prachtige plein voor de Kasěpoehan te gaan teekenen, in onbeholpen trant zooals hij het zelf later noemt. Dus blijft hij er hangen, om in Mei te Tĕgal te zijn, en die plaats tegen Juni weer te verlaten. Een algemeen ontvanger en een houtvester vertellen over hun ambt, een controleur over koffiecultuur en landrente, een oud-administrateur over de geschiedenis der Pamanoekan- en Tjiasĕmlanden, een ingenieur over den spoorwegaanleg en een handelsemployé over den importhandel. Zoo wordt de kring van verwerkte wetenswaardigheden steeds uitgebreid.

Er zou, nog afgescheiden van al het feitenmateriaal, dat hier ligt opgetast, een heele verhandeling te schrijven zijn over de meeningen en stemmingen, die toentertijd in verantwoordelijke Indische kringen 
blijken geheerscht te hebben. Het is hier niet de plaats om daarover eenigszins uitvoerig te zijn, maar een enkel citaat moge toch doen zien, wat Rouffaer al zoo op kon teekenen: „Al wat particulieren klagen over tegenwerking van het B. B." meent een der zegslieden, ,komt enkel van den kant der residenten, dat op Java verre van een keurcorps is, zoo zelfs dat er misschien nog geen 3 goede zijn. De residenten op de buitenbezittingen veel beter. De G. G. moet beginnen met wantrouwen en moet dan na eenigen tijd verbeteringen in gaan voeren, maar in eens radikaal kàn hij niet te werk gaan; zoo zou daar b.v. ook toe behooren dat hij alle residenten van Java bijna op eens op zwart zaad zette, hetgeen indien die allen pensioen moesten hebben de tegenwoordige financiën te veel zou bezwaren. De eenigst mogelijke radikale verandering zou uit Holland kunnen komen net als met de commissarissen-generaal van weleer. Dan ook zou er een radikale herschepping in de wetgeving moeten plaats hebben, daar niemand een weg weet door al de besluiten, wijzigingen en wijzigingetjes heen. Op een frisschen grond moest dan een frisch gebouw opgetrokken."

Forsch ingrijpen uit Nederland dus? Neen, zegt een andere autoriteit. „Dat men voortdurend in Holland van de Indisch-Europ. samenleving denkt, dat het zulke slechte menschen zijn, versterkt waarachtig de band niet. Integendeel men vervreemdt al meer en meer van mekaar. Alleen redding is mogelijk als de 2e kamer het budgetrecht laat varen; maar blijft het zoo, ziet men alle pogingen tot verbetering van hier uit beproefd spaak loopen en de Hollanders volharden in hun dwaze neuswijsheid, dan gaat Indië onherroepelijk voor Holland te gronde." Ja nog sterker, deze heer — wij herhalen het, lang niet de eerste de beste - constateert als publieke meening, door hem zelf gedeeld: ,als morgen de Nederlandsche vlag door de Duitschers of een andere Europeesche natie wordt neergehaald, dan zal er niemand in Indië zijn, die zich één oogenblik uit vaderlandsliefde zal verzetten."

Een ander waarschuwt weer voor een binnenlandsch gevaar: „Al meer en meer worden de meeste Indo-Europeanen op ons verbitterd; buitengewoon op hun punt van eer gesteld, dapper, goede schutters, moeten zij taktvol behandeld worden en er voor gewaakt dat zij zich te eeniger tijd met de inlanders en Chineezen tegen ons mochten verbinden." En dan de inlanders! Die koopen maar steeds geweren, aangezet door panghoeloe's en dergelijke menschen; één firma verkocht te Bandoeng voor $\mathrm{f} 1000$ in de maand geweren aan inlandsche 
clientèle! Het is waarlijk geen wonder, dat tusschen al zulke verhalen, hoe waardevol ook ter kenschetsing van de gevoelens der Europeesche maatschappij, van tijd tot tijd aan Rouffaer zelf wel eens een hartige opmerking uit de pen vloeit.

Hij zelf heeft in Juni en Juli 1886 een merkwaardigen tijd doorgebracht op de suikeronderneming Tjomal bij Pĕkalongan. Aan zijn gesprekken met den administrateur S. W. C. van Musschenbroek danken wij vele bladzijden met goed gedocumenteerde bijzonderheden over de suikerindustrie en alles wat daarmee samenhangt; en ook de spoedig volgende studie van verdere suikerlitteratuur als Millard, De suikerbelasting, en Hülsmann, De suiker (sterk afgekeurd), hangen ongetwijfeld met dit verblijf samen. Voortdurend blijft trouwens de suiker in de Aanteekeningen een voorname rol spelen; men bedenke, dat dit juist de jaren zijn even na de zoogenaamde suikercrisis. Te midden van dat alles wordt geconstateerd, dat de toegemeten tijd om van alles kennis te nemen nog te krap is, en wordt de reis dus opnieuw met een jaar verlengd.

Merkwaardig is het verblijf te Tjomal echter vooral in een ander opzicht, en wel omdat hier de dichtader weder is gaan vloeien, en in hoe sterke mate! In de enkele maand Juli werden 35 gedichtjes vervaardigd, en daarvan komen er 15 op de datums 4 en 5 Juli. De toon in de eerste producten is over het algemeen somber, gelijk men reeds uit titels als Wroeging, Doffe wanhoop, Geknakt leven, Wanhoop in Indië, kan opmaken; uit dezelfde dagen is de reeds aangehaalde Toewijding aan zijn zuster, waaruit berusting spreekt, en zoo blijkt ook verder de depressie voorbijgaand, en vinden wij evengoed Natuurgenot en een paar Minneliedjes. Een herhaaldelijk beproefd onderwerp is dat van Jong Holland en Indië; en dan is ook het genre van actueel-politiek dichtwerk vertegenwoordigd, bijvoorbeeld door een vers, dat ,Jan Pietersz. Coen en de 2e kamer” heet. Coen is er niet veel meer dan een aanloopje, en verder gaat het vooral over de in de oogen van Rouffaer verderfelijke wijze waarop de Kamer gekozen wordt : hier herkent men weer den discipel van Multatuli. Een later gedicht „Parlementaire betweterij over Ned. Indië" verraadt zijn inhoud door het opschrift; ook elders blijkt trouwens overvloedig Rouffaer's opinie. Een zijner Aanteekeningen vangt hij bijvoorbeeld aan met de woorden: „Een nieuwe bijdrage tot de kennis der parlementaire walgelijkheden is...." enz.

Wij willen hier nog één proeve van zijn dichterlijk talent invoegen, en wel een, waarop hij zelf bijzonder gesteld was. Hij heeft 
het herhaaldelijk verbeterd en overgeschreven en had het bestemd om te prijken als inleiding voor zijn groote dichtwerk, waarover zoo straks nog nader.

\section{DE OLIJFOOGST.}

In steen en kalkbrok staat de olijfboom vast.

Uit stugge kluiten

Doet hij ontspruiten

Den balsem waar de wond zich aan vergast,

En de olie wast

In starren bast

En perst heur droppels uit de vrucht naar buiten.

De gele herfst bij 't breken van de blaên,

Als vruchten vallen

In duizendtallen,

Houdt nog een poos dien stroeven boom belaên,

En schijnt begaan

Met af te staan

Wat telken jaar hem heilrijks moet ontvallen.

Doch eindlijk zie ik volle manden gaan;

En vrouwen joelen

En mannen woelen

$\mathrm{Nu}$ vrucht na vrucht ten persbak is gedaan,

Die, volgelaên,

Aan de overdaên

Der malsche olijf zijn gretigheid mag koelen.

De olie die er druipt in aarden kruiken

$\mathrm{Zal}$ heinde en veer

En telkens weer

Haar smijdigheid voor de open wond gebruiken;

Of neer gaan duiken

$\mathrm{Bij}$ 't wreed verstuiken

En lenigen het schrijnen meer en meer.

Zóó treedt ten boezem uit van enkle mannen

Een balsemvocht

Dat heelen mocht,

Den strakken geest der lijders doen ontspannen,

Het leed verbannen

Van 't hartespannen, - - ....

Waarbij 't aan eigen pijn en smart niet docht ! 
In het laatst van de maand zijn het vooral vaderlandsche herinneringen, dennebosch, storm en sneeuw, die den dichter inspireeren; en dan volgt op $30 \mathrm{Juli}$ een aan J. W. Retgers opgedragen gedicht met het refrein: ,Ik, ik hoop nog,” hoop namelijk niettegenstaande allerlei dat anders zijn moest, waarbij dan ,de domme Tweede Kamer" weer de reeks besluit.

Gedurende de volgende maanden verschijnen de gedichten nog slechts schaars. In Augustus vertoeft Rouffaer te Pĕkalongan; hij schrijft er het artikel over Bataviasche schilderijen, dat wij later bespreken, en verneemt vele bijzonderheden van een koffieplanter, ditmaal zeker geen toevallig bezoek, want hij heeft reeds uit Batavia een deel van zijn bagage naar hem toegestuurd. En dan, in de tweede helft van September, komt hij voor het eerst tegenover Baraboedoer te staan.

Wij hebben reeds gewezen op het feit, dat de Aanteekeningen zoo goed als niets over de Javaansche kunst bevatten; het is alsof die geheel buiten de belangstelling van den onderzoeker valt. Zelfs Baraboedoer maakt geen uitzondering; de eenige maal, dat het monument genoemd wordt, is het om heel kort de opmerking van Groneman te registreeren, dat de regeering goed gedaan zou hebben door Leemans, voor hij zijn groote boek schreef, eens naar Indië te sturen. Maar naast deze negatieve houding in het algemeen, hebben wij nog iets positiefs, in den vorm van een op 21 September 1886 te Baraboedoer gedateerd gedichtje. Het heet.... De eerste lentedag.

Hier wrijft men zich toch wel even de oogen uit. Ziehier nu de man, die zijn landgenooten zou leeren de aesthetische beteekenis van Baraboedoer, het kunstwerk-voor-alle-tijden, te verstaan. Hij komt voor het eerst voor dat wonderwerk te staan, hij grijpt in de snaren en dicht.... over den winter, die weg is en de zon die weer gaat schijnen. Hoe moet dit verschijnsel worden verklaard? Een dag of tien later zal de sombere schoonheid van het Diëng-plateau hem ook slechts inspireeren tot een rijm "Aan would-be dichters”. Aan het feit, dat de Hindoe-Javaansche oudheden, die later zulk een groote plaats in zijn leven innamen, bij de eerste kennismaking verre beneden de aandacht bleven aan allerlei actueele onderwerpen besteed, valt dunkt ons niet te ontkomen. Hebben zij hem slechts langzaam en geleidelijk kunnen grijpen, of heeft hij opeens in een later stadium van zijn leven, toen hij al weer ver weg was in Holland, hun taal leeren verstaan? $\mathrm{W}$ ij weten het niet, maar deze eerste aanraking blijft ons met verbazing vervullen. 
In September is Rouffaer in Sĕmarang en bespreekt er allerlei met zijn vriend Retgers; in den loop van October is hij te Magĕlang. Wij zien weer uit de Aanteekeningen, welke studie hem deze maanden bezig houdt. Het zijn de particuliere landerijen, aan de hand van Riesz voor Java en Van Dissel voor Celebes; het is een nauwkeurig nagaan van de wijze, waarop indertijd de Agrarische Wet in de Tweede Kamer is behandeld; en verder het gevangenis- en dwangarbeid-stelsel volgens Wiselius. Maar wat hem nog meer rechtstreeks moet hebben vervuld is, dat hij de eerste hand ging leggen aan de twee groote werken, waarvan hij toen ongetwijfeld verwacht heeft, dat zij eenmaal zijn naam zouden vereeuwigen zuiver wetenschappelijke aspiraties waren hem nog altijd vreemd een geweldig dichtwerk, de Tijdzang aan Amsterdam, en een niet minder breed opgezet boek over Multatuli.

Terwijl wij de samenstelling van den Tijdzang vrij nauwkeurig kunnen volgen, weten wij van het werk over Multatuli alleen, dat Rouffaer er in November 1886 aan begonnen is en er tot in 1887 aan bezig is geweest. De figuur van Multatuli had hem sinds zijn studententijd niet losgelaten; in de Aanteekeningen worden voortdurend, tot het laatst toe, allerlei Multatuliana aangetroffen, naar aanleiding van lectuur of van ontmoetingen met menschen, die iets van zijn Indischen dienst wisten. Midden in het manuscript van den Tijdzang teekent Rouffaer aan: „Bericht ontvangen van Retgers, dat Multatuli gestorven is. 23 Februari 1887. 11/1/2 uur 's morgens. Ambarawa." De aanteekeningen zijn nu eens bewonderend, dan weer kritisch, en men gevoelt, dat Rouffaer bezig is voor zichzelf uit te maken, hoe hij deze merkwaardige figuur moet beschouwen en beoordeelen. Vandaar dan ook ongetwijfeld de behoefte om zichzelf en anderen schriftelijk van dat alles rekenschap te geven. Meer en meer trouwens moest het ook hemzelf duidelijk worden, dat de Multatulistudie in veel opzichten samenviel met wat hem zoo bezig hield inzake Indische toestanden; allerlei bijzondere vragen bleken zich te laten herleiden tot de hoofdvraag: „Is de verv̉anging van het cultuurstelsel door de liberale koloniale politiek heilzaam geweest of niet?” en daarbij rees vanzelf in de eerste plaats de gestalte van Multatuli op.

Van het boek zijn slechts fragmenten gereed gekomen, maar er is een uitvoerige Inleiding, en daaruit leeren wij den opzet kennen. Immers het slot van die Inleiding luidt als volgt:

„Uit eigen ervaring weet $\mathrm{ik}$ hoezeer het een goede daad mag 
heeten een vooral duidelijk, zoo mogelijk glashelder oordeel over Multatuli aan het leven te helpen; niet alleen het met mij opgegroeide geslacht, maar iedere nieuwe generatie van jongelingen die met hem dweepen zullen gelijk wij met hem dweepten, zou er voordeel van hebben op rechtvaardige wijze den weg zich te zien gewezen in den lang niet gemakkelijk te doorschrijden doolhof van Multatuli's gevoelens en denkbeelden, sterke en zwakke plaatsen.

„Om nu te trachten iedereen daartoe een kluwen in de hand te geven, zal ik beproeven een geleidelijke schets te maken van Multatuli's geestelijke voorbereiding - zijn Lehr- und Wanderjahre als het ware - , daarna van den tijd en de omgeving waarin hij ging optreden, om aldus tot een juiste waardeering te geraken van zijn voorbijgaande en blijvende beteekenis. Ik verdeel daartoe dit eerste deel in de volgende hoofdstukken:

1. De voorbereidings-tijd van Multatuli tot het schrijven van den Max Havelaar.

2. De godsdienstige spanning in Nederland omtrent 1860 .

3. De eerste periode van Multatuli's openlijke werkzaamheid.

a. De Max Havelaar.

b. De Minnebrieven en Verspreide Stukken.

4. De tweede en laatste periode van Multatuli's leven.

a. De Ideeën tot en met den 5en bundel.

b. De kleinere geschriften uit de tweede periode.

c. De 6e en 7e bundel Ideeën en de Millioenen-Studiën.

5. De historische beteekenis van Multatuli samengevat.

6. De tegenstrijdigheden in Multatuli's geest en Multatuli's persoon.

7. De letterkundige beteekenis van Multatuli, vergeleken met Potgieter en Busken Huet.

8. Besluit over den invloed van Multatuli op Nederland.

Terwijl ik voor het $2 \mathrm{e}$ deel striktelijk den persoon van Multatuli als Havelaar bewaar."

Ziedaar het programma. Wat is er in deze jaren van tot stand gekomen ? Behalve de reeds genoemde Inleiding voor het eerste deel (De invloed van Multatuli op Nederland) is er een stuk van die voor het tweede (De invloed van Multatuli op Nederlandsch-Indië); dan is er een fragment van het eerste hoofdstuk (Voorbereidingstijd) en een heel groot stuk (39 bladzijden fijn geschreven folio) van het tweede (Godsdienstige spanning). Voorts hebben wij een beschouwing over de liberalen en Thorbecke en het begin van het zevende hoofdstuk (Letterkundige beteekenis), met afzonderlijke fragmenten 
over Busken Huet, Vosmaer en Van Hoëvell; ten slotte een stuk over de drukpers in Indië. Er is bij dat alles zeer veel dat, met talent en overtuiging geschreven, een even onderhoudende als belangrijke lectuur vormt en waarvan het te betreuren is, dat het in handschrift moet blijven sluimeren; in het bijzonder geldt dat bijvoorbeeld van de bespreking over Van Hoëvell, die er als voorlooper van Multatuli en bovenals als ongerept, eerlijk en onbaatzuchtig man, in tegenstelling tot anderen, op den voorgrond wordt gebracht. Een afzonderlijke studie over het Nederlandsche nationale type, geheel in denzelfden geest geschreven als de Multatuli-fragmenten, dateert ongetwijfeld eveneens uit dezen tijd.

Uit bovenstaande opgave blijkt intusschen nog niet, wat ten slotte Rouffaer's oordeel over Multatuli is geweest, doch ook omtrent de strekking van het werk als geheel licht de Inleiding ons in, en wel door het formuleeren van hetgeen de auteur zich voorstelt aan te toonen, ten einde de taak, die hij op zich neemt, in enkele woorden duidelijk samen te vatten. Het zal zijn:

,hoe Multatuli waar hij direkt strijd voerde tegen de hem omringende toestanden, meeningen en personen, de meest scherpe en radikale woordvoerder is geweest van de geweldige krisis, welke tusschen de jaren 1850 en 1875 in het meerendeel der gemoederen van het beschaafde Nederlandsche publiek plaats greep, eerstens godsdienstig, dan ook zedelijk, verstandelijk en maatschappelijk;

„hoe Multatuli dus in zóóverre een denker en schrijver is geweest, wiens eenzijdigheid, geringe degelijkheid en revolutionnaire partijdigheid hem de aanspraak ontzeggen op voortdurende waardeering door volgende geslachten; en hem alleen als noodzakelijk uitvloeisel van den geest dier overgangs-jaren een bij uitstek in het oog vallende geschiedkundige plaats toestaan;

„hoe Multatuli echter, waar hij zich niet onmatig liet ergeren door menschen of dingen om hem heen, doch zich enkel liet inspireeren door de in hem gelegde geniale vonk, over buitengewone gedachten en over een buitengewonen vorm kon beschikken, als nooit te voren aan één Nederlander ten dienste stonden;

,hoe Multatuli dus zich daarin en daardoor onsterfelijk heeft gemaakt ;

„,hoe echter door verandering in de opvatting zijner roeping, Multatuli met het aanvangen van de uitgave zijner Ideeën een periode begon waarbij zijne denkbeelden wel duidelijker aan het licht traden, doch de vorm van het geheel belangrijk schade leed; 
„hoe dus in korte woorden: Multatuli's werken overvloeien van ideeën en betoogingen, die, daargelaten haar hooge historische waarde voor het derde kwartaal der 19e eeuw, de twintigste eeuw niet zullen halen en reeds op het huidige volwassen geslacht heur grooten invloed verloren hebben; doch tegelijk, en gril daardoor heen geworpen, gedeelten bevatten die met volle recht der onsterfelijkheid deelachtig zullen blijven; welke gedeelten men regelmatiger ontmoet, naar mate men meer tot het jaar 1860 terug gaat.

„Dit zijn, zoo te zeggen, de stellingen die ik ga bewijzen.”

En nu Rouffaer's gevoelens ten opzichte van Multatuli in een meer persoonlijken vorm, namelijk zooals hij ze neergelegd heeft in zijn brief van rouwbeklag aan Multatuli's weduwe. De omstandigheid, dat hij dien brief heeft opgenomen in de Inleiding tot het tweede deel, bewijst, dat hij ook zelf wenschte dat het publiek er kennis van zou nemen, en dat de publicatie te dezer plaatse dus geen onbescheidenheid is. De brief luidt als volgt:

\section{Mevrouw!}

Moeilijk kan ik nalaten $\mathrm{U}$ mijn bitteren rouw te betuigen bij den vreeselijken slag die $\mathrm{U}$ trof. Ik waag het niet mij den omvang van Uw leed te denken; doch ik voel behoefte $\mathrm{U}$ mede te deelen hoezeer Multatuli's dood voor mij een ontzettende treurmare was.

Het innigst griefde mij wel dat hij heen is gegaan zonder dat iemand in Nederland den moed blijkt bezeten te hebben om een waarachtige, van haar eigen ongereptheid zich bewuste kritiek het leven te schenken. Een kritiek die haar beste had trachten te geven van dat onpartijdige standpunt waarop een onderwerp als Multatuli's leven en streven moet geoordeeld worden.

Zoo innig graag had ik zulk een beoordeeling nog zien verschijnen vóór zijn dood: het zou zulk een weldaad zijn geweest voor Nederland vooral, dat dan geen felle wroeging zou voelen knagen nòòit tijdens Multatuli's leven aan Multatuli recht te hebben gedaan !

En daarom ook is met zijn dood een illusie mij weggenomen. Al moge het zijn dat juist zijn sterven menigeen in staat stelt een onpartijdiger standpunt zich te veroveren, - nooit zullen de Nederlanders het heerlijk gevoel kunnen hebben met open gelaat en gewasschen handen Multatuli tegemoet te zijn getreden. Nooit voor hun lange zwijgen hem nog een boek te hebben aangeboden waarin zij. op die eerlijke wijze als het gemoed wil, met hem hadden getracht 
af te rekenen; schuldbelijdende zeker voor een goed deel, zich reinigend wellicht voor een ander.

Zij hebben de gelegenheid laten voorbijgaan; nu heeft hen de gelegenheid verlaten.

En juist dit stemt mij droevig in de hoogste mate. Ik toch was bezig te beproeven wat mijne krachten vermochten; sedert November 1885 reiscle $\mathrm{ik}$ in Indië rond, en was reeds na eenige maanden ontbolstering bezig alles omtrent de Havelaarzaak en meer nog omtrent den invloed van Multatuli op de koloniën bijeen te verzamelen. Sedert November 1886 bovendien was ik begonnen met het neerschrijven van fragmenten die deel zouden uitmaken van mijn studie over Multatuli's inwerking zoo op Nederland als Nederlandsch-Indië. In de laatste helft van 1888 in Holland terugkeerend, hoopte ik mijn arbeid in het midden van 1890 uit te geven.

Was het tè egoistisch, te hopen dat Multatuli — dertig jaren na de verschijning van zijn Max Havelaar! — tot zoolang mocht leven?

Mevrouw! Wil het rouwbeklag aannemen van iemand die veel geleerd en veel genoten heeft van Uwen afgestorvene; en die, als het vergund was geweest, had willen beproeven nog tijdens Multatuli's leven hem met een eerlijke kritiek open te gemoet te treden.

Mijn plan blijft; mijn werk zal op den eens bepaalden tijd hopelijk verschijnen. Hoef ik $U$ echter te zeggen welke illusie mij ontnomen is?

Wil nogmaals, Mevrouw, het bittere, bittere medelijden aannemen van wie zich teekent

Uw dw. dr.

G. P. ROUFFAER.

Ambarawa (Java), 2 Maart 1887.

Ten slotte nog één citaat, dat ons zal doen begrijpen, hoe Rouffaer de kwestie-Multatuli in het groote verband der Indische politiek zag. Deze in 1887 neergeschreven beschouwing doet ons tevens blijken, hoe het boek over Multatuli, al is het dan onvoltooid gebleven, toch zijn dienst aan Rouffaer zelf en aan de wetenschap heeft gedaan, door zijn ingrijpende en later zoo vruchtbare studie over Indische toestanden in deze richting te sturen.

„Ik geloof geen valsch profeet te wezen”, zoo zegt hij in dezelfde Inleiding tot het tweede deel, ,wanneer ik beweer dat de liberaalkoloniale politiek, welke sedert 1848 begon te leven, in 1854 met 
het Regeerings-Reglement een halve overwinning bevocht, om met de Comptabiliteits-wet in 1864 en de daaruit gevolgde onderwerping van het geheele geldelijk beheer over Indië aan de almacht der Tweede Kamer de volle zege te behalen, - dat die liberaal-koloniale politiek met het tweemanschap van den Gouverneur-Generaal Van Rees en den Minister van Koloniën Sprenger van Eijk haar laatste woord heeft gesproken. Voor wie een gevoelig oor en een helder oog heeft, staat het vast, beweer ik, staat het voor de overtuiging onomstootelijk vast, dat er een nieuw tijdperk moèt en zàl aanvangen voor Indië, in verhouding tot Nederland. Een tijdperk waarin de Tweede Kamer een goed deel van haar almacht zal moeten prijsgeven, aan Indië meer zelfbestuur wordt geschonken, en zoowel in Nederland als in Indië zelf decentralisatie het middel zal blijken om de vele nooden der tegenwoordige koloniale verhoudingen te lenigen en te verhelpen. Ja zelfs houd ik mij innig overtuigd dat wij heden ten dage in die eigenaardige overgangs-periode ten opzichte der koloniën verkeeren, waarin - gelijk in alle analoge tijdsgewrichten - van alle kanten een dof gemompel van stemmen zich verheft, dat aangroeit en aangroeit, tot plotseling het verbaasde publiek, en een groot deel der mompelaars zelven ook, tot de gewaarwording komen dat de geheele stemming veranderd en het woord tot omkeering van richting reeds gesproken is.

„In zulk een hachelijken tijd van overgang — altijd, mits ik geen valsch profeet blijke! - waarin overhaasting even schadelijk is als het wachten met het verzetten der bakens tot het getij verliep, gevaarlijk, acht ik het vooral van het hoogste gewicht te trachten een zoo helder mogelijke uiteenzetting te geven van de hoofdfactoren die onze Indische toestanden beheerschen, om daardoor ieder die mee wil denken in de gelegenheid te stellen zich rekenschap te geven van de overmijdelijke eischen des tijds, maar hem tevens bewust te doen worden welke voorzorgsmaatregelen moeten genomen, wil de nieuwe hervorming niet, zooals zoo vele andere, wel verandering maar geen verbetering blijken te hebben gebracht. Ik zal toch, naar ik hoop, bij machte zijn duidelijk te maken hoe op de verhoudingen van onze overzeesche bezittingen zulke abnormale, zulke geheel op zich zelf staande invloeden inwerken dat elk voorstel tot hervorming hetwelk niet op de meest ernstige wijze met hen rekening houdt, een slag in de lucht mag heeten; neen, erger, een roekeloosheid en een strafbare lichtzinnigheid mag gescholden worden. „Koloniale keezen”, zoo zijn op het voetspoor van

D1. 84. 
Busken Huet ${ }^{1}$ ) die oppervlakkigen in Indië - en in Nederland! tc noemen welke zonder degelijk onderzoek, en slechts doordravend op eenige van buiten geleerde leuzen, er geen been in zouden zien een heele maatschappij den sprong in de duistere toekomst maar te laten wagen, zonder in hun wuftheid te vragen of deze beweging soms een sprong in den afgrond kon blijken. Van die koloniale keezen nu heb ik er bij menigte in Indië ontmoet, velen in geschriften, meer nog in persoon, meest van al in kranten.

„Met dat al ben ik, zoo goed als de heftigste koloniale utopist, vast overtuigd dat een hervormings-tijd voor Indië moet en zal aanbreken; en zelfs niet binnen langen tijd. Daarom nu wil ik beproeven de resultaten van mijn persoonlijk onderzoek mede te deelen; eerst zal Havelaar de hoofdpersoon blijven, te belangwekkender omdat juist hij het best den overgangstijd kenmerkt der koloniale politiek tusschen de jaren 1848 en 1870 - het jaar waarop de hoogst invloedrijke Agrarische Wet werd aangenomen - ; daarop zal de sedert 1870 op ingrijpende wijze veranderde toestand van Nederlandsch-Indië onderzocht worden ten opzichte van die samenstellende factoren welke het meest belangrijk zijn; en ten slotte wil ik beproeven mijn denkbeelden omtrent hervorming samen te stellen uit oordeelkundige kombinatie der bij mijn onderzoek aan het daglicht getrokken hoofdelementen.

„Wie mij moge verwijten daarbij niet enkel me meer tot Douwes Dekker te beperken, en eigenlijk een gebied te betreden waarop ik niemand in het eerste deel had voorbereid - het zij zoo! Ik echter vond de gelegenheid ongezocht, tegelijk met de kritiek van sedert dertig jaren vervlogen Indische toestanden waarin de strijdhafte figuur van Max Havelaar de meest opmerkelijke blijft, er aan vast te knoopen een geleidelijk overzicht van de sedert nog verder veranderde verhoudingen. Zelfs voor hem die zich alleen voor Havelaar interesseert heeft dit het groote voordeel des te beter zijn vollen invloed op Nederlandsch-Indië te kunnen overzien, te meer daar ik elke gelegenheid te baat zal nemen ieder spoor van dien invloed ook nà 1870 met den vinger aan te wijzen. Maar bij allen die minder bekrompen van zin zijn, zal het bovendien toejuiching vinden dat ik nog nader de vruchten van mijn driejarig verblijf in Indië tracht neder te leggen in een studie, waarin toch reeds naar aanleiding van

1) In een noot wordt verwezen naar Nationale Vertoogen, 1876, II blz. 143 en 144. 
Multatuli's persoon zooveel moest gesproken worden over de verhouding van Nederland tot zijne bezittingen in Azië."

Ziedaar dus het plan, zooals het zich in 1887 had ontwikkeld. Vastknoopend aan de figuur van Multatuli wordt de verdere studie dienstbaar gemaakt aan het leeren kennen der gewijzigde toestanden en het aangeven van noodzakelijke hervormingen. Het is dus uit dit oogpunt, dat wij Rouffaer's verderen Indischen arbeid, die zich ten slotte nog anderhalf jaar verder heeft uitgestrekt dan hij op dat oogenblik voornemens was, hebben te beschouwen.

Belangwekkend voor de kennis van zijn persoon is nu, dat hij tegelijk met het werk over Multatuli, dat hem zoozeer in beslag moest nemen, ook den dichter in zich kon en wilde doen spreken. Wij noemden reeds den Tijdzang aan Amsterdam. Op 24 October 1886 is dit gedicht te Magĕlang begonnen, voortgezet gedurende een kort verblijf te Ambarawa en gedurende de maand November in Sĕmarang, terwijl er dan vooral aan gewerkt is toen Rouffaer sinds December zich voor een langer vertoef te Ambarawa gevestigd had. Daar werd op 29 Maart 1887 de laatste strofe van hetgeen gereed gekomen is op papier gezet; inmiddels was de auteur sinds Februari aan het overschrijven bezig, en bestond er in April een volledige net-copie. Daaraan is in later jaren nog voortdurend gevijld en gewijzigd, en nog tot twee maal toe is het geheel weer gecopieerd: in 1890/91 en in 1892 voor een toen beraamden druk. Maar voortgezet is het dichtwerk na Maart 1887 nooit.

De Tijdzang aan Amsterdam! Welk een moeite en zorgen, welk een toewijding en inspanning zijn er aan besteed. Verzen en stukken van verzen, strofen en reeksen van strofen zijn weer gewijzigd en geschrapt, nieuwe regels werden toegevoegd, omzettingen hadden plaats, en zoo is er een eindeloos zwoegen uit de vier exemplaren te lezen. En nog was het niet naar den zin van den auteur, want ook in de copie voor den druk is nog allerlei opengelaten, klaarblijkelijk om nog den definitieven vorm te krijgen, die den schrijver geheel zou bevredigen. En dan als resultaat deze verzenmassa, welke men, hoeveel goeds de details ook hier en daar opleveren, toch wanneer men het geheel beschouwt geen dichtwerk zal mogen noemen.

Vergeefsche moeite? Stellig niet. Wat moet het voor Rouffaer een vreugde zijn geweest, zich in staat te weten, om zijn gedachten en gevoelens tot uiting te brengen in den poëtischen vorm, waarin hij dat wenschte, zijn wereld- en levensbeschouwing in deze achtregelige strofen uit te zingen. Zeker, er bleef ook voor zijn eigen 
idee altijd nog wel wat te verbeteren, maar hij zag dan toch dat door voortdurend vijlen het steeds meer aan zijn ideaal beantwoordde en hij was voldoende overtuigd geslaagd te zijn, om tot den druk te kunnen besluiten. Men moet, dunkt ons, juist voor zijn eigen geestesgesteldheid de ervaring, dat hij tot zulk kunstwerk in staat was, speciaal in deze voor zijn verderen levensloop zoo gewichtige jaren, niet gering aanslaan.

Dat het ten slotte niet tot een druk is gekomen, zal hem een bittere teleurstelling hebben bespaard, en wellicht heeft zijn voor anderer werk zoo kritische geest toch eigenlijk ook wel de mogelijkheid van zulk een teleurstelling voorvoeld en is daarom de druk niet doorgezet. Het is én voor Rouffaer én voor de vaderlandsche letterkunde toch maar beter, dat deze, in eersten aanleg meer dan tienduizend versregels, het manuscript niet verlaten. Ze zijn vooral van waarde voor wie er den auteur uit wil leeren kennen.

De opzet is grootsch genoeg, en allerlei stukken zijn er bij, die getuigen van dichterlijk gevoel en groot beeldend vermogen. Maar daarnaast is er al te veel, waar de lezer in bespeurt, hoe weerbarstig de woorden en de versmaat waren, en hoe de schrijver ze tot zijn wil heeft moeten dwingen. Dat is lang niet altijd gelukt; en er zijn gevallen van afgeknotte of uitgerekte woorden en gewrongen zinswendingen, waar men zich verbaasd afvraagt, of aan dezen Multatulikenner het befaamde stuk uit de Ideeën, waar het treurspel Floris V van mr. Willem Bilderdijk wordt ,afgeslacht”, geheel onopgemerkt is voorbijgegaan.

Te zeggen, dat de Tijdzang een poging is om Dante na te volgen, zou geheel ongerechtvaardigd zijn, want een navolging is het in geen enkel opzicht; maar wel is het een feit, dat men in den schrijver den bewonderaar van Dante dikwijls en met voorbedachten rade ziet te voorschijn treden. Inderdaad heeft Rouffaer aan Dante veel studie gewijd, en voor zijn handexemplaar der Divina Commedia, hetwelk hem na aan het hart lag, heeft hij dan ook een bijzondere beschikking gemaakt.

Wat van den Tijdzang gereed gekomen is, is de Voorzang, in eersten opzet 272 strofen beslaande, later aanmerkelijk verkort, en zes deelen van den Hoofdzang, met tezamen nog 869 strofen. Het werk is opgedragen ,,aan de onvergetelijke nagedachtenis van mijn oudste zuster" en begint met het hierboven reeds geciteerde gedicht „De olijfoogst” als veelbeteekenend voorbericht. 
O heerlijk is het dolen in een bosch,

Waar de eigen voet alleen het blad doet kraken, zoo zet de Voorzang in met een boschmijmering en het vaardig worden van den geest. Het beeld van Amsterdam verrijst:

En dan treedt Gij, met heel uw tal van tinnen, Schoon Amsterdam, te-voorwaart uit den vloed Die telkenmaal den strijd weer wil beginnen, En telkenmaal toch ook weer wijken moet.

Het water wordt bezongen, en dan verheft zich de zang tot de eenheid in de natuur en de eenheid in den mensch, om met de eenheid in Holland, gerepresenteerd door Vondel en Rembrandt, te eindigen.

Het eerste deel van den Hoofdzang is getiteld: „Inleiding. Persoonlijke herinneringen". De dichter in uit den strijd in een veld van licht getreden en herdenkt zijn verleden, Kampen en zijn onbezorgde jeugd, Delft, dat in den ,wreeden strijd van hooge en lage driften" zooveel ontvreemdde en verscheurde, en dan de rust in het liefelijke Diepenveen, waarbij hij gedenkt wat hij zijn zuster en Vitringa dankt: den laatste de innerlijke klaarheid terzake van Multatuli, den ,beste(n) prikkel van mijn jonglingsdagen”. Diens vermelding brengt hem dan weer op Amsterdam, dat hij zal bezingen.

Den geweldigen opzet van den zang beseft men eerst goed, als dan het tweede deel den titel blijkt te hebben: „Christus geboren. Het Evangelie der Liefde verkondigd aan Joden, Grieken en Romeinen". Wij kunnen er natuurlijk niet over denken den rijken inhoud der telkens ontwikkelde gedachten weer te geven en bepalen ons tot de titels.

Het derde deel heeft zijn definitieven vorm nog niet gekregen, maar uit den voorloopigen, wel wat wijdloopigen, titel: „Het onsterfelijkheids-geloof. Beeldende en vormende invloed der Grieken. De opvatting der Liefde door Plato. De Emanatie-leer van Plotinus. De Bijbel. Een Katholiek-Christelijke Kerk ontstaat", blijkt hoe de zang zich verder ontplooit. In het vierde deel wordt behandeld: „De Katholiek-Christelijke Kerk vereenigt zich te Rome met de Imperatorgedachte en de Roomsch-Katholieke Kerk ontstaat. Gregorius VII. De Roomsche Kerk krijgt haar hoogste inwendige kracht. Instelling van het College van Kardinalen, het Coelibaat en de Investituur. Hendrik IV. Canossa”. Met het vijfde deel zijn wij an: „Florence. Naast de Roomsch-Katholieke Kerk begint de kunstenaar zijn open- 
baring, de poorter zijn persoonlijke vrijheid te verstaan. Dante". Een groot deel van dezen zang wordt ingenomen door de visie van Dante zelf, die den dichter met een „Kom tot mij, jongling” aanroept en met hem spreekt; en dan volgt een merkwaardig stuk, waarbij de lezer van bewondering in verbazing vervalt, als Dante van den auteur wil weten, waar hij hem het eerst bekoord heeft, en clan verneemt, dat dit op de zeereis naar Java (,Voorlichter heette 't volle driemastschip") heeft plaatsgevonden; ook het relaas van den grooten storm wordt nog gegeven. Het stuk is niet een van de mooiste maar zeker een van de voor Rouffaer meest typische passages van het heele gedicht.

De zesde afdeeling geeft: „Venetië. De vrije Staat naast de vrije Kerk. De Venetiaansche schilderschool". Maar wanneer dan deze ,zee die stad werdt, stad die weer tot zee $U$ zaagt vervormd in 't wisslen van Uw werken” is verheerlijkt, klinkt de kreet „Land!” der ontdekkingsreizigers en moet de dichter heen - of laten wij het hem liever met zijn eigen woorden hooren zeggen om in de slotstrofe van den zang iets van de deugden en van de gebreken van den Tijdzang te gevoelen.

Dan, - ik moet heen ! De wonderroep van „Land !”

Sleept ook mij mee op nieuwe ontdekkingstochten. „Amerika!” „Oost-Indië !” me overmant.

Een ńieuwe aêm vaart door Europa's lochten.

Dit tijdperk sluit. Een nieuwer slaakt zijn rand.

Een laatste aanblik vóór ' $k$ dat nieuws ga duiden !...

Vaarwel, Venetië ! Zeesirene in 't Zuiden !

Vaarwel, Venetië ! - Amsterdam wordt bruide !

En daarmede is het dan uit, definitief uit, want het beloofde nieuws is nooit geduid en juist op het oogenblik, dat het hoofdonderwerp van den Zang wordt genaderd, houdt de dichtader op te vloeien. Een aanteekening achter een der concept-cahiers doet vermoeden, dat de Hollandsche kunst allereerst behandeld zou worden, en wij, behalve over Vondel en Rembrandt, nog een en ander over Cuyp, Hobbema enz. gehoord zouden hebben. Er is echter geen regel van op papier gezet.

Vanwaar dit zwijgen? Dat het boek over Multatuli niet verder gekomen is, is begrijpelijk genoeg. Zooeven zagen wij reeds, hoezeer gaandeweg het tweede deel, dat over den Havelaar, in Rouffaer's oog in belang had gewonnen en wijder strekking kreeg, en hoe de auteur het uitsprak zich over alles, niet alleen wat de Havelaar- 
zaak betrof, maar wat de koloniale politiek in het algemeen aanging, grondig te willen en te moeten documenteeren. De tijd, dien hij dacht nog in Indië te zullen doorbrengen, was betrekkelijk gering en er moest van geprofiteerd worden. Het spreekt dus eigenlijk wel vanzelf, dat het aanvullen of schrijven der stukken, die evengoed later in het vaderland samengesteld konden worden, voorloopig achterwege moest blijven en alle aandacht zou worden geconcentreerd op het werk, dat alleen in Indië zelf kon plaats hebben, het verzamelen van materiaal. Dit klemt temeer, omdat bij de voortgezette studie in de Vorstenlanden de vraag van het werkelijk wezen van den agrarischen rechtstoestand Rouffaer zóó heeft aangegrepen, dat hij aan pogingen om deze te beantwoorden zijn verder onderzoek hoofdzakelijk heeft gewijd. Multatuli geraakte daarbij vanzelf eenigszins op den achtergrond.

Ten deele kan eveneens tijdsgebrek het voorloopig laten liggen van den Tijdzang ten gevolge hebben gehad: ook deze moest wijken voor de noodzakelijkheid der studie van Indische toestanden. Doch zou, als de inspiratie had doorgegloeid, de dichter zich bij die noodzakelijkheid hebben kunnen neerleggen en niet veeleer, evenals tevoren, te midden van het andere werk, hoe druk ook, aan den dichterlijken drang hebben moeten toegeven ? Daar komt bij, dat cok de kleinere gedichtjes verstommen. Dat daar te midden van het groote dichtwerk geen roeping voor bestond, ligt voor de hand, het eenige kleine vers uit dien tijd is dan ook geen gedicht, maar een verzuchting op rijm over "Indische begrootingsdiscussien in de $2 \mathrm{e}$ Kamer" (Jan. 1887). Daarop volgt echter gedurende alle verdere Indische jaren, zooals wij zien zullen, nog slechts één gedicht in Juli 1887, en een laatste in Nederland in December 1890. Men kan dus veilig zeggen dat met het eindigen van het behandelde stuk Tijdzang Rouffaer als dichter heeft uitgesproken.

Het is mogelijk, dat naast de ingespannen studie daar ook het feit toe heeft medegewerkt, dat hij in de tweede helft van zijn Indischen tijd door een onvoorzichtigheid zijn gezondheid ernstig in de waagschaal heeft gesteld; in later jaren zinspeelde hij daar nog wel op en zocht er de bron van zijn voortdurend gesukkel. Ook dat kan hem de lust tot dichten benomen hebben. In elk geval, de inspiratie schijnt verder te hebben ontbroken, en Rouffaer heeft zijn talent in deze richting geen geweld aangedaan, doch er zich bij neergelegd, zich bepalend tot de herziening van den Tijdzang. Wij zien hem dus de volgende jaren voortdurend studeeren en 
materiaal verzamelen, thans echter niet, zooals in het begin, alles opschrijvend wat hem maar eenigszins belangrijk voorkwam, doch zich bepaaldelijk richtend op één welbewust doel. Niet als zou nu alles, wat daar buiten lag, op eens uit de belangstelling zijn verdwenen; in datzelfde jaar 1887 worden bijvoorbeeld nog uitgebreide aanteekeningen neergeschreven over Luther en Calvijn, hetgeen kan samenhangen met de kerkelijke beweging in het vaderland, maar ook materiaal voor den Tijdzang kan vertegenwoordigen, en wellicht zonder eenigen samenhang met dat alles eenvoudig toont, dat de aandacht op deze kerkhistorische aangelegenheden was gevallen. Over het algemeen echter gaan de Aanteekeningen steeds duidelijker bewijzen, dat de belangstellende toerist was veranderd in een hartstochtelijk onderzoeker van de Javaansche toestanden.

Gedurende het verblijf te Ambarawa was het vooral de controleur J. de Kock, die talrijke wetenswaardigheden tot de Aanteekeningen bijdroeg, evenals de auditeur-militair daar ter plaatse. Of Rouffaer ook na April nog te Ambarawa heeft vertoefd, blijkt niet; eerst in Juni treffen wij hem weder aan te Koedoes. En dan begint, in de tweede helft van Juni 1887, het verblijf in de Vorstenlanden, dat in zijn gevolgen van zoo uitnemend belang zou worden en in wetenschappelijk opzicht het hoogtepunt van Rouf faer's eerste Indische reis vormt.

Op 21 Juni te Soerakarta aangekomen, waar hij ruim twee maanden zou verblijven (tot 28 Aug.), woonde Rouffaer er reeds den 23sten zijn eersten garěbĕg bij; ook de Gouv. Gen. Van Rees was toen aanwezig. Zoo staat hij midden in het Javaansche leven en gaat de studie der Vorstenlanden aanvangen. Thans allerminst als een liefhebberij, maar als een plicht, waarvan hij de zwaarte ging gevoelen. Teekenend in dat opzicht is het laatste Indische gedicht, gedagteekend $20 \mathrm{Juli}$, en getiteld „Bittere Studie”.

Niets wilde ik zien als bloemen om mij heen

En tooi van blad en bontbegraasde weiden,

En rieken dennelucht mij suizlend van de heide

Die eerst nog werd bevrucht met geur van boekweit-veen.

Maar nu, o God mijn God, zijn het slechts menschenreên

Die door den warrelzin van boeken mij verleiden

Het rustelooze hoofd aan hunnen waan te wijden,

Terwijl het arme hart blijft troosteloos alleen !

En heimlijk stijgt er op een troosteloos geween

Van uit den grond der ziel, die al den last moet lijden

Van 't slovende verstand en diens wanhopig strijden

Om rede te gebiên aan dwaasheid om mij heen. 
Ziedaar de geest, waarin de Vorstenlandsche studie wordt aangevat.

In het najaar van hetzelfde jaar 1887 heeft het eerste bezoek aan Jogja plaats (28 Oct.-10 Dec.); dan komt Rouffaer weer op Solo terug (20 Dec.-20 Jan. 1888), vertoeft een paar maanden te Rĕmbang (22 Jan.-23 Maart), is dan weer op Solo, thans een half jaar (8 April-13 Sept.), onderneemt een reis naar Bali (3 Oct.12 Nov.), vertoeft dan een vol jaar te Jogja (15 Nov. 1888-25 Nov. 1889), en gaat weer terug naar Solo, vooral Klaten, waar hij tot Februari 1890 blijft. Hij is dus bijna steeds in de Vorstenlanden zelf, met uitzondering van korte onderbrekingen.

Eerst iets over de beide meer gewichtige onderbrekingen, hierboven reeds genoemd, Rĕmbang en Bali. Bij beiden staat een persoon in het middelpunt: Ch. te Mechelen en H. N. van der Tuuk, en beiden ontleenen dan ook hun belang vooral aan dien hoofdpersoon.

Charles te Mechelen, dien Rouffaer zijn ,grooten vriend” noemt, de bekende Javanicus, was op dat oogenblik ter standplaats Rĕmbang, met den rang en titel van resident, ,tijdelijk belast met de leiding der maatregelen ter zee tot bestrijding van den opiumsmokkelhandel". In die functie was hij de man, met wien de doeltreffende strijd tegen deze smokkelarij bij het toen heerschende opiumpacht-stelsel stond of viel; op zijn voorstel was het aanhalen van clandestiene opium van den vasten wal naar de zee overgebracht, en met een waren hartstocht zwierf de ,residèn laoet” langs de kusten van Java en Bali om er telkens zijn slag te slaan. Hij was natuurlijk eveneens de man, die meer dan iemand anders van de opium en wat daarmee samenhangt afwist, al heeft hij dan ook niet het inzicht gehad, dat het heele pachtstelsel zou dienen te verdwijnen; maar voor Rouffaer was hij ook nog iets anders. „Voor wie hem gekend hebben, zooals ik hem heb gekend", schreef deze na Te Mechelen's dood, „,met zijn groote persoonlijke bekoorlijkheden en zijn zoo vergeeflijke menschelijke fouten, was hij een verkwikkende, tintelende verschijning; een bij wien men dat zeldzame gevoel kreeg den prikkelenden geur in te ademen der wijde Javaansche boschvelden, en het geheimzinnig ritselen te hooren van neervallende djatiblaren."

Het „In memoriam” van 1918, waaraan deze woorden ontleend zijn, geeft de herinnering aan den Te Mechelen van 1888, de krachtfiguur, kranig ruiter, jager vol ijzeren zenuw, en ook met zijn oogenblikken waarin hij zichzelven vergat. Daar heeft Rouffaer dan die 
twee maanden vertoefd, en er met de ,heerlijke hulp” van zijn gastheer hard gewerkt. Vele volgeschreven zijdjes over de opium geven er getuigenis van, en daarbij zijn heel wat ,bescheiden in het archief van den resident ter zee H. L. Ch. te Mechelen”, met een schets der ontwikkeling van diens ideeën ter bestrijding van den smokkel.

$\mathrm{Na}$ Te Mechelen, met een half jaar tusschenruimte, Van der Tuuk. Ook diens beeld is door Rouffaer geschetst, zij het meer terloops ${ }^{\mathbf{1}}$ ); diens wonderlijke uiterlijke verschijning, grove, rauwe stem en zonderlinge varkens-oogjes, en zijn leven in een bamboe-huis te midden van een ongeloofelijken rommel, alles onder duimdikke stof. Gelogeerd heeft Rouffaer er niet, zooiets moedigde Van der Tuuk ook volstrekt niet aan; maar wel heeft hij er eens ,ontbeten”, en daar het voorgezette voedsel een soort van Compagnie's-victualie bleek te zijn, heeft hij zich voorgenomen dat nooit weer te doen. Een apart cahier is met aanteekeningen van Bali, gesprekken met Van der Tuuk en eigen opmerkingen, gevuld. Voor Van der Tuuk, dien ,,stuurman in de groote vaart, met taalgenie”, heeft hij als taalgeleerde grooten eerbied gekoesterd, maar daar bleef het dan ook bij; Te Mechelen daarentegen was het welke ,'gevoelens wakker riep, die in innigheid tot liefde naderden".

Behoudens deze onderbrekingen heeft de Vorstenlandsche studietijd twee en een half jaar, meer dan de helft van het heele Indische verblijf, in beslag genomen: Gelijk wij reeds opmerkten, eindigen de Aanteekeningen met de eerste maanden van 1888; men kan er dus nog juist in waarnemen, hoe de studie in eersten aanleg is opgezet. Het zijn bijna uitsluitend de agrarische toestanden, die de aandacht trekken, en waarbij in de eerste plaats wordt geconstateerd, dat Veth, Pierson en De Louter groote fouten maken. De theorie, dat de Vorst de absolute eigenaar van den grond is, vormt het uitgangspunt, hetwelk dan vooreerst aan de hand van het Rapport over het grondbezit in Soerakarta van den resident A. J. Spaan - voor Rouffaer een openbaring - , tot een heel systeem wordt ontwikkeld, in al zijn consequenties. Dan is aan de orde datgene van Spaan's redeneeringen en conclusies, waartegen de resident van Jogja, B. van Baak, en de hem voor den landverhuur toegevoegde controleur C. A. Rosemeier in hun Nota's zijn opgekomen, en een en ander wordt weer aangevuld door inlichtingen, rechtstreeks door den heer Rosemeier verstrekt. Verdere litteratuur, en een overzicht

1) Op p. XIV* vlg. van de Brandes-Herdenking. 
der regelingen van 1847 en 1873 wordt gevolgd door mededeelingen uit levende bron, o.a. den secretaris van Solo, Engelbert van Bevervoorde; dan komen voor de historische wording, Nota's en artikelen van Winter, memories en derg. sinds den Compagniestijd, het Pĕpakĕm Tjarbon, de gevolgtrekkingen, die uit het reisverhaal van Van Imhoff te maken zijn; ten slotte weder een ondernemer en administrateur als man van de practijk. Midden in dien, ten deele onuitgewerkte en in potlood op kleine papiertjes aanwezige gegevens, eindigen de Aanteekeningen. Eenige losse cahiers geven dan verdere aanwijzingen over den loop zijner studiën. Wij zien daarbij, dunkt ons, hoe Rouffaer, zonder iets prijs te geven van de voordeelen der informatie bij deskundigen en uit publicaties, zijn onderzoek daarenboven uitbreidt en verdiept door archiefstudie. Het is juist door ook deze historische bronnen te gebruiken, ze kritisch te bekijken en hun gegevens te combineeren met het van andere zijde en uit hedendaagsche toestanden geleerde, dat hij tot zulke opmerkelijke resultaten heeft kunnen geraken. In de nieuwe werkmethode, die met de Vorstenlandsche archiefstudie een aanvang neemt, begroeten wij voor het eerst Rouffaer als wetenschappelijk vorscher.

Zelf heeft hij dan ook terdege het hooge belang van wat hij in de archieven vond, begrepen; sinds Juni 1888 werkt hij te Solo met drie Javaansche schrijvers en talrijk zijn de afschriften van archiefstukken, welke onder zijn nagelaten papieren worden aangetroffen. De meesten zijn van agrarischen aard, maar er zijn er ook over andere Vorstenlandsche aangelegenheden, over de opium, en verdere aanteekeningen op historisch en administratief gebied, ook uit de Gouvernementslanden, een beschrijving van de garĕbĕg, enz. Nog in een ander opzicht is zijn rustig en langdurig verblijf in de Vorstenlandsche omgeving van groot belang geweest voor de volledigheid zijner documentatie: er komen hem thans ook allerlei gegevens van Javaansche zijde in handen.

Een eerste tastbare resultaat van de op deze wijze verworven ongemeene bekendheid met de Vorstenlandsche zaken is, dat als tegen Mei 1889 de resident van Jogja Van Baak op aftreden staat, het Rouffaer is, die de Nota van overgave van het bestuur samenstelt. De toerist, die drie en een half jaar te voren Java voor een plezierreis had betreden, zonder iets van Javaansche toestanden af te weten - ,de koloniale politiek was mij geheel vreemd, en mocht ik als Prins Maurits bij de praedestinatie, het van hetzelfde belang achten of zij groen dan wel blauw van kleur was", zegt hij zelf - had zich 
ontwikkeld tot een erkende autoriteit, een Indische specialiteit in den besten zin des woords. In Juni 1889 stelde hij, op instigatie van F. A. Liefrinck, een schema voor een Agrarische studie op, vooral om na te gaan, wat nog verder moest worden nagespeurd. Het is bij een onvoltooid ontwerp gebleven.

Bij een dergelijk onderzoek is het altijd moeielijk om uit te maken, wanneer men het als afgesloten kan beschouwen, en Rouffaer was er niet de man naar om spoedig tevreden te zijn. Misschien had hij dus nog verder willen werken, en het lag voor de hand, dat op den duur ook Oost-Java nog wel bezocht zou zijn geworden, evenals de Buitenbezittingen, die van den aanvang af op zijn programma hadden gestaan. Er is niets meer van gekomen. Een hevige chronische malaria had zich van hem meester gemaakt, en dwong in het voorjaar van 1890 tot een snel vertrek. Tot ongeveer 20 Februari vertoefde hij nog te Klaten, maar daarna is hij linea recta naar Batavia gereisd, en op 1 Maart met het stoomschip Conrad naar het vaderland vertrokken. Op 3 April was hij weder in Nederland, na een bijna vijfjarige afwezigheid.

III.

Wanneer Rouffaer zich na zijn terugkeer heeft gevestigd aan de Weesperzijde te Nieuwer-Amstel, is hij voorloopig uitsluitend patient. Gelijk wij zagen, was zijn bedoeling geweest allereerst, als hij weder in het vaderland zou zijn, zich bezig te houden met het boek over Multatuli en daarmede af te doen wat hij voelde als een schuld van Nederland tegenover dien voorganger; een taak, die hem te liever moest zijn, nu in het tweede deel zooveel zou moeten worden verwerkt van hetgeen hem de studie der Javaansche toestanden in het algemeen had geleerd. Er was geen sprake van, dat zulk een werk van grooten adem thans mogelijk zou zijn, en de fragmenten over Multatuli zijn zóó blijven liggen, als ze te Ambarawa waren opgesteld. Evenmin was er voorloopig de gelegenheid om in anderen vorm of ander verband iets van de resultaten der reis te publiceeren, zoodat ook de agrarische studie bleef liggen.

Slechts één bescheiden stukje zag voorloopig het licht, en daaruit is al heel weinig op te maken, wat Rouffaer in Indië had verricht. Het is een verslagje over de oude schilderijen, bij zijn komst te Batavia daar aangetroffen, en in Augustus 1886 te Pĕkalongan beschreven; het stuk was ingezonden bij Oud-Holland en daar in 


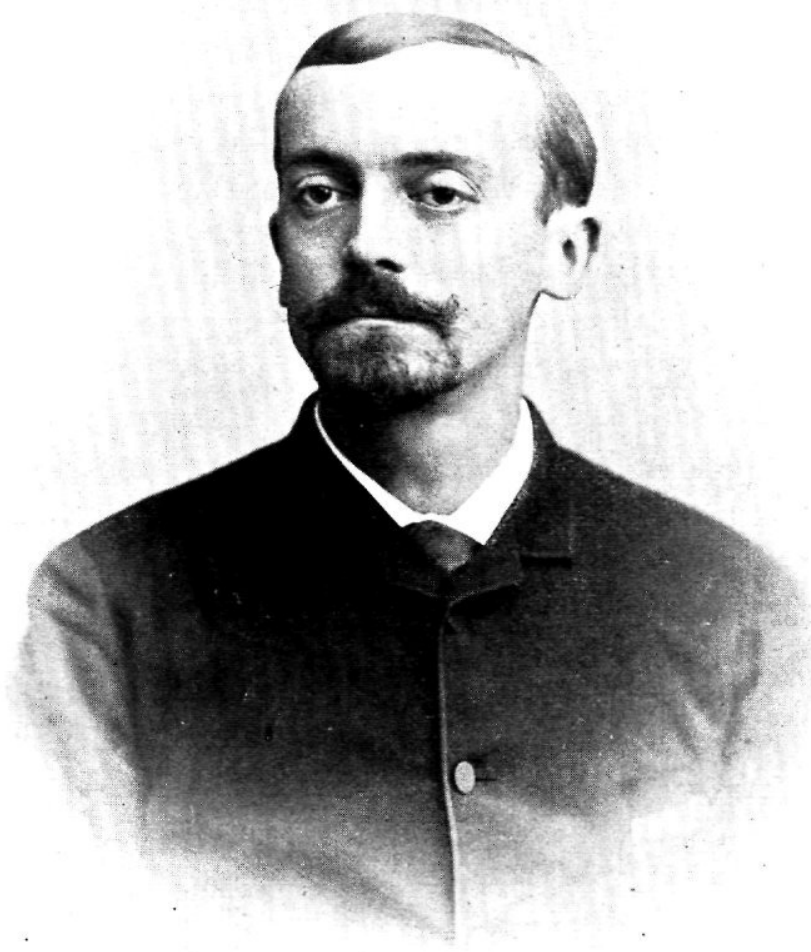

G. P. ROUFFAER,

op ongeveer 30-jarigen leeftijd. 
portefeuille gebleven, totdat eindelijk in 1894 de redactie tot plaatsing overging. Het betreft de serie conterfeitsels der GouverneursGeneraal, van Pieter Both af, bewaard in de vergaderzaal der Hooge Regeering ten paleize aan het Waterlooplein, en nog eenige andere portretten in de antichambre. De landvoogden zijn copieën van de ellendigste soort; de goede portretten zelf zijn, hoe dan ook, verdwenen. Doch in een mansportret, vergeten hangend op een donkere plaats in het bureau van den secretaris van den Raad van Indië, kon Rouffaer een origineelen Slabbaert van voortreffelijke kwaliteit herkennen. De stukken in de antichambre zijn wat beter dan die uit de vergaderzaal, en bovendien hangt daar nog één prachtstuk, het portret van Lord Minto door Chinnery ${ }^{1}$ ). De auteur stelt voor, deze beide schilderijen van waarde naar Amsterdam te doen verhuizen; het artikel, dat te Pĕkalongan natuurlijk niet behoorlijk gedocumenteerd kon worden, is door de redactie van noten voorzien. De schrijver heeft er klaarblijkelijk bij den druk niets meer aan gedaan.

De eenige levensteekenen, die van den Rouffaer der Amsterdamsche jaren 1890-1892 tot ons zijn gekomen, zijn de wijzigingen aan den Tijdzang, en een klein gedichtje, in December 1890 aan Retgers gewijd, „mijn boezemvriend J. W. Retgers”, zooals het thans heet; het gedicht heet „Innige vriendschap", en het warme gevoel, dat er uit spreekt, heeft te worstelen met den dichtvorm, die de sporen draagt niet, heel vlot te voorschijn te zijn gekomen. Het gedicht is, zooals wij reeds zeiden, het allerlaatste van Rouffaer's hand.

Retgers was toen in Europa, en was in 1889 te Leipzig gepromoveerd; in November had hij een dag of twaalf bij zijn vriend gelogeerd en er den Tijdzang gelezen en van opmerkingen voorzien; het exemplaar voor den druk werd later ook in zijn handen achtergelaten. Rouffaer had het zelf niet meer gereed kunnen krijgen; zijn ziekte maakte het noodzakelijk, dat hij elders genezing zocht. Dat zou geschieden, nadat eerst Zwitserland was geprobeerd, in het hem van vroeger reeds bekende Spanje; en zoo vertrok hij in Januari 1893 naar Granada. Retgers is tijdens de afwezigheid van zijn vriend in 1896 overleden; in de Koninklijke Akademie van Wetenschappen

1) Een goede afbeelding van het portret, met begeleidend artikel van J. de Loos-Haaxman, is te vinden in Ned.-Indië Oud en Nieuw 12 (1927-28) p. $314-320$. 
werd hij herdacht als een groot geleerde, tevens iemand van zeldzame teruggetrokken bescheidenheid.

Rouffaer's verblijf in Spanje heeft ruim vier jaar geduurd. Groot werk was van den herstellenden zieke niet te wachten, maar zijn belangstelling, onverflauwd als steeds, richtte zich op iets, dat hem van ouds had geinteresseerd, en dat hij thans in zijn onmiddellijke nabijheid had, den Roomsch-Katholieken eeredienst. Drie cahiers heeft Rouffaer in Spanje met gegevens over symboliek, ritus, gebruiken, gewoonten, benamingen, feesten, kleeding, enz. volgeschreven. Deze, zijn aanteekeningen in boeken, benevens de herinneringen en ervaringen neergelegd in zijn "Spaansche indrukken” in De Gids van 1898, zijn hetgeen hij uit Spanje mee terugbracht.

Over de cahiers mogen wij kort zijn, daar wij de waarde van den inhoud moeilijk kunnen beoordeelen. Het is duidelijk, dat een onvermoeid navorscher, tevens scherp opmerker, aan het woord is. Uit alle mogelijke bronnen worden de gegevens bijeengezocht, en dan gecombineerd met hetgeen de eigen oogen van den schrijver om zich heen zagen; en bij de opgemerkte bijzonderheden wordt onderscheid gemaakt tusschen wat elders ook wel zoo zijn zal en hetgeen speciaal Spaansch is. Een en ander wordt gerangschikt onder verschillende hoofden, b.v. een uitgebreid onderzoek over de consequentie van het onderscheid tusschen de Evangelie- en de Epistel-zijde in de kerkgebouwen; dan over heilige getallen, over misceremoniën en liturgie, over apparaten, vaatwerk, kleedij, over het klokgelui, maar vooral over feestdagen en wat daar aan vast zit, en wel zeer in het bijzonder de Paaschweek.

De uit eigen ervaring opgeteekende eigenaardigheden hebben hoofdzakelijk betrekking op Granada zelf. Het oudste bericht, waarbij een datum staat is, als wij goed hebben gezien, van Januari 1894; het voorafgegane jaar zal de patient ook wel weinig gelegenheid hebben gehad voor iets anders dan voor zijn gezondheid te zorgen. Een enkele opmerking is van 1895, de groote meerderheid is in 1896 neergeschreven. Eindelijk blijkt in April 1897 nog een mis te zijn bijgewoond te Toledo, dat moet dus kort voor den terugkeer naar Nederland zijn geweest. Ook aangaande andere plaatsen geven de aanteekeningen duidelijk te kennen, dat zij op persoonlijke waarneming berusten, en zoo weten wij van bezoeken aan Sevilla, Córdoba, Salamanca, Zamora en Leon.

Men meene nu niet, dat het langdurig verblijf in Spanje Rouffaer eenigermate van Nederland zou hebben vervreemd. Zijn medeleven 
blijkt op origineele wijze uit ingezonden stukken van tijd tot tijd in de Nieuwe Rotterdamsche Courant, nadat hij reeds in 1894 de gelegenheid had aangegrepen iemand in „De Amsterdammer” (nummer van $10 \mathrm{Juni}$ ) op zijn vingers te tikken, die een onjuiste meening had ten beste gegeven over het auto de fé. De stukken in den Rotterdammer ${ }^{1}$ ) loopen volstrekt niet over Spaansche zaken, maar doen de belangstelling van den inzender voor Indische aangelegenheden kennen; zoo in datzelfde jaar 1894 om de wenschelijkheid te betoogen van een spoedigen druk van het door den in dat jaar overleden Van der Tuuk in manuscript nagelaten Kawi-Balineesch-Nederlandsch Woordenboek, en in het begin van 1895 om te waarschuwen tegen het opschroeven van het door de Lombok-expeditie behaalde succes, en het zotte plan tot oprichting van een museum-Vetter. Overigens heeft generaal Vetter zelf ook te kennen gegeven, het vreugdebetoon in Holland overdreven te achten. Eveneens in 1895 wordt Rouffaer ter verdediging van de eer van het geliefde Amsterdam in het geweer geroepen, om de ergerlijke tekortkoming van den dan juist verschenen - en hem klaarblijkelijk naar Spanje opgezonden - plattegrond aan te toonen, en als de bewerker zich tracht te verdedigen, wordt in een voluit onderteekend stuk de kwalificatie ,slecht en slordig" nog eens ter dege onderstreept.

In 1896 weer andere zaken: rectificatie van een bericht over een heiligendag, de slechte uitspraak door Hollanders van de $r$ (onderteekend $\mathrm{R} \ldots \mathrm{r}$ ), de wenschelijkheid der uitgave van een zakatlas van de Nederlanden, Oost- en West-Indië en Zuid-Afrika. Rouffaer heeft ook later heel wat ingezonden stukken in de wereld geholpen en wij zullen ze natuurlijk niet alle vermelden, doch voor die uit den Spaanschen tijd mocht een uitzondering gemaakt worden om hetgeen ze ons leeren van Rouffaer's blijvend contact met het vaderland.

Het laatste van de stukken in den Rotterdammer heeft den omvang van een artikel en kondigt den eersten nationalen Baedeker voor den Archipel aan, den „Reisgids voor Nederlandsch-Indië, samengesteld op uitnoodiging der Kon. Paketvaart-Mij., door dr. J. F. van Bemmelen en G. B. Hooyer.” Deze eerste proeve is uitstekend uitgevallen, al zijn er natuurlijk desiderata; één daarvan is, dat in het geheel niet gerept wordt van een op Java zeer gemakkelijk middel van rondreizen in de hoogere streken, nl. te voet, met een koelie voor de

1) 19 Oct. 1894 ; 10 Jan. 1895 ; 14 Aug. 1895 ; 12 Sept. 1895; 14 Maart 1896; 12 Sept. 1896; 1 Oct. 1896; 6 en 7 Nov. 1896. 
bagage. Dit onvermengd en goedkoop genot kent Rouffaer bij ondervinding.

Belangrijk is nu verder, hoe hij constateert, dat wie de som zijner indrukken na een bezoek der koloniën wil weergeven, scherp moet onderscheiden tusschen het Merkwaardige en het Schoone. Aan het eerste, het nieuw-interessante, went men op den duur, hoe verbijsterend het ook in het begin is. Het schoone, het heerlijke, blijft, en het is drieërlei : het Indische bergland, de kleinere Indische eilandenwereld en de Indisch-Hindoesche kunst.

Terwijl nu de Gids in de behandeling van bergland en kleine eilanden wordt geprezen, schiet hij ten opzichte van de kunst te kort. Dat is niet de schuld der samenstellers; het komt omdat tot op heden de zuiver-artistieke waarde der kunst in onzen Indischen Archipel nog onontdekt ligt. Aanknoopend bij een polemiek te dezer zake tusschen de heeren Jan Veth en Niermeyer in de Kroniek en den Amsterdammer van Maart en April 1895, constateert Rouffaer, dat de slechte behandeling der Indische kunst op een algemeen-nationale fout berust. Van Baraboedoer, zegt hij, vinden we een beschrijving, waarvan soms de haren te berge rijzen; over Bali, het heerlijke, poëtische, artistieke Bali, wordt ons wijs gemaakt, dat men er Boeddhistische tempels en instellingen kan bestudeeren, verder niets, maar deze volslagen nonsens is goud waard. Over Panataran wordt niet gerept, inzake de Pasoeroeansche tjandi's wordt gesproken van oudheden met een lakonische kortheid, als ware het oud roest; alleen Prambanan krijgt een paar behoorlijke bladzijden, doch de Diëng wordt weer met een paar woorden afgedaan.

Dat alles is slechts mogelijk, omdat het bewustzijn dat er kunst, waarachtige kunst, in onze koloniën te genieten valt, zoo goed als afwezig nog is bij zelfs begaafde Nederlanders. Daar moet natuurlijk verandering in komen. En wanneer dan die Indische kunst ,te harer tijd eens om kunst-wille zal behandeld en gewaardeerd worden, dan zullen er blijken te zijn twee dingen van hooge waarde: de oude, verdwenen, meest overgedragen kunst op Java, de Hindoe-oudheid; en de jonge, vrijwel nationale, en wat vooral in deze tijden zoo hoogst merkwaardig is, 1 e ve n d e, springlevende kunst der Baliërs op Bali en een deel van Lombok; terwijl dan als appendix daar een ding van minder waarde, meer ethnologisch-interessant, aan toegevoegd zal moeten worden: de slappe, zwakke, op oude herinneringen terende huidige kunstnijverheid op Java en Sumatra's Westkust vooral, dan ook in andere deelen van onzen Archipel." 
Voor het zoover is, moet nog heel wat vóór-arbeid plaats hebben, maar deze dient dan ook ondernomen te worden; een tweede druk van den reisgids moge een degelijke rubriek over de antieke Hindoekunst en de levende Balineesche kunst bevatten.

Wij hebben dit stuk wat uitvoerig weergegeven, omdat het in een courant niet zoo gemakkelijk meer bereikbaar is, en omdat het de eerste maal is, dat Rouffaer iets over zijn inzichten op het gebied der Indische kunst heeft laten drukken. Hij doet het dadelijk met eenige autoriteit, en is zeker van zijn zaak. Zou hij dan toch op Java de oudheden, op Bali de levende kunst, bestudeerd hebben en het stilzwijgen der Aanteekeningen misleidend zijn? Wij gelooven het niet. Wel heeft hij dat alles gezien en er zijn indrukken van gekregen, maar op dat oogenblik waren het stellig zaken, die pas in de tweede plaats voor hem in aanmerking kwamen. Het onderzoek naar de huidige toestanden en hun wording ging voor, al is het mogelijk dat gedurende de tweede helft van zijn Indische reis, waarin geen Aanteekeningen zijn opgeschreven, de nabijheid van Jogja en Prambanan een meer intieme kennis van laatstgenoemd oudhedencomplex heeft in de hand gewerkt. In het algemeen echter schijnt het, dat eerst gaandeweg de indrukken van de Indische kunst zich verdiept hebben, en Rouffaer zich volkomen rekenschap is gaan geven van wat die kunst beteekende. De kennismaking met het werk van Groeneveldt, IJzerman, Verbeek en Groneman, dat hij grootendeels eerst na zijn vertrek uit Indië kan hebben leeren kennen, en dat hij in zijn stuk vermeldt, kan er toe hebben bijgedragen. Hoe het ook zij, als Rouffảer Spanje verlaat, heeft hij zich over de kunst van Indië een eigen en merkwaardig juist oordeel gevormd.

Het is voorts aannemelijk, dat hij, naarmate hij zich beter is gaan gevoelen, zijn studie niet uitsluitend is blijven beperken tot den Roomsch-Katholieken eeredienst. Zijn uit den aard der zaak groote bedrevenheid in het Spaansch moet hij hebben aangevuld met die van het Portugeesch; en reeds in de jaren van zijn buitenlandsch verblijf zal hij zich zijn gaan toeleggen op de studie van de Portugeesche en Spaansche geschiedschrijvers, die voor Indië van belang zijn. Wanneer hij slechts betrekkelijk kort na zijn terugkeer, iedereen kan verbazen door zijn ongemeene vertrouwdheid met deze auteurs in hun verschillende edities, kan het niet anders of de grondslag voor die kennis moet reeds van te voren gelegd zijn. Het ligt trouwens voor de hand, dat wanneer te voorzien is, dat het Spaansch verblijf op den duur niet meer noodig zal zijn, de gedachten naar hervatting

D1. 84. 
der voorgenomen Indische studie gaan, en daartoe in de eerste plaats wordt ter hand genomen wat met het oog op de aanwezige hulpmiddelen in Spanje beter dan in Nederland te bestudeeren is.

Zijn landgenooten in het algemeen heeft Rouffaer aan zich verplicht door de reeds genoemde „Spaansche indrukken”, eenige maanden na zijn terugkeer geschreven. Onder dezen bescheiden titel verbergt zich een prachtige karakteristiek van Spanje, het land en het volk, het dorstige Spanje, en de harde aard van den Spanjaard, dor en eenkleurig, met felheid waar hartstocht over hem komt, de Spanjaard in de politiek en in den godsdienst, de tegenstelling tusschen stedeling en boer, het Spanje van de stierengevechten en van de Jezuieten, het Spanje van de groote Kathedralen, het Spanje van Cervantes en Velasquez. Het is geen artikel om er den inhoud van te registreeren, maar wil men Rouffaer in zijn beste kwaliteiten als opmerker en als kunstenaar leeren kennen, dan neme men de Spaansche indrukken ter hand.

Door het uitgangspunt van het stuk, het geven van indrukken, komt er ook wel een en ander van persoonlijken aard bij te pas, en daar willen wij nog een oogenblik bij stil blijven staan. Daar is vooreerst de herinnering, nog uit den Deventer-tijd, van de wijze, waarop voor het eerst Spanje was betreden: de aankomst per boot te Cartagena, de fel witte stad tegen de ruige steenrotsen, en dan de spoorreis naar Madrid, eerst langs het Oostersche Murcia, tusschen palmen, sinaasappels en olijven, dan door de woestenij van verdord uitgevreten leem, en eindelijk de hoogvlakten van het binnenland. Daar is ook die visie op Toledo, boven op zijn granietrots, gezien als de trotsche versteening van ridderdom en strijdhaftigheid, en zoo Spaansch in den meest wezenlijken zin. Daar zijn bovenal de beschrijvingen van de wandelingen in de omgeving van Granada, in het verrukkelijke wildland, door de weelde van een zuidelijke landouw of de beklemming van een dorre woesternij, over de liefelijkheid van een wildbloeiend heuvelland of in de stille verlorenheid van vochtige dalgronden. Zoo krijgt men Spanje's natuur allengs zeer sterk lief. Dieper dan waar ook leert men hier het geheim der vreugde van het dolen verstaan.

Wanneer er een enkele maal een vergelijking wordt gemaakt, dan leveren daarvoor zoowel de Hollandsche polderweide als het Javaansche berglandschap de stof. Spanje is Rouffaer altijd na aan het hart blijven liggen; toen hij ziek van zijn tweede Indische reis terug- 
kwam, hoopte hij er weder herstel te zullen vinden, en ook later had hij nog wel eens de illusie Granada terug te zien.

'In welke maand precies Spanje voor goed is verlaten, is ons niet gebleken. Doch in de tweede helft van 1897 was Rouffaer opnieuw gevestigd te Amsterdam.

Het zou thans niet voor lang zijn. De studie werd weder ter hand genomen, thans vooral in historische richting, maar ook op het gebied van kunst en kunstnijverheid, en dit bracht bezoeken aan musea en boekerijen elders mede, en daaronder ook aan het Koninklijk Instituut in den Haag. Het was toen gehuisvest op de Heerengracht no. 21 , en was in het bezit van een bibliotheek, terwijl in dezelfde ruimte ook de boekenverzameling van het Indisch Genootschap was ondergebracht. Met ,ondergebracht” is voor beide bibliotheken ook alles gezegd. De boeken lagen gedeeltelijk op zolder en de heele collectie verkeerde in een meer of minder chaotischen toestand, zoodat eigenlijk niemand er goed weg in wist. In theorie berustte het beheer bij de secretarissen der beide instellingen, die jaren lang hun boekverzamelingen gescheiden bleven houden; eerst kort te voren was het denkbeeld gerijpt om ze te combineeren tot één koloniale bibliotheek.

In zulk een boekerij te moeten werken beteekende voor een man als Rouffaer natuurlijk in de eerste plaats ergernis, daarna de vraag, of het niet mogelijk was in dien toestand verbetering te brengen, en eindelijk het besef, dat hij zelf de hand an het werk zou kunnen slaan om een verzameling, die op haar speciale gebied zooveel bijzonders bevatte, ook inderdaad aan haar doel te laten beantwoorden. Impulsief en belangeloos als hij altijd was, zette hij nog in datzelfde najaar van 1897 dit besef om in een daad, door zijn aanbod aan den secretaris van het Instituut, toentertijd den heer E. B. Kielstra, om de noodige orde te scheppen in de verzamelingen boeken en kaarten. Het aanbod werd, gelijk begrijpelijk was, gaarne aanvaard. Zoo begon Rouffaer met het inventariseeren der kaartenverzameling.

Zijn werkzaamheden daaraan hadden vooreerst ten gevolge, dat hij herhaaldelijk en bij voortduring in den Haag moest zijn, en voorts dat de heer Kielstra den arbeid van dezen merkwaardigen vrijwilliger op hoogen prijs leerde stellen en begreep, dat het zaak was zich deze hulp ook voor de toekomst te verzekeren en Rouffaer blijvend aan het Instituut te verbinden. Toen de Catalogus der land- en zeekaarten van het Instituut gereed en bijna afgedrukt was, achtte hij 
het oogenblik gekomen om dat denkbeeld te verwezenlijken. Hij deed dit na overleg met Rouffaer zelf. Deze had zich, hetzij om dit vooruitzicht, hetzij omdat het ook zonder dien vasten band voor zijn werk beter uitkwam het voortdurend heen en weer reizen te vermijden, inmiddels in den Haag, Witte de Withstraat 25, neergezet. Hij woonde er reeds in Augustus 1897, en ontving er in het volgend voorjaar Brandes, voor deze naar Indië terugkeerde.

Ondershands moet de zaak zijner aanstelling in Juli 1898 geregeld zijn, want er bestaat een dankbetuiging van Rouffaer aan den heer Kielstra, gedateerd $10 \mathrm{Juli}$, na de verblijdende tijding dat alles zóó spoedig geheel naar wensch in orde was gekomen. Uit dat briefje blijkt tevens, dat Rouffaer op dat oogenblik zich ook nog met andere zaken bezighield, en wel met de studie van Javaansche bronzen in het Museum van Oudheden te Leiden.

In de Bestuursvergadering van het Instituut van 17 September 1898 kreeg de benoeming van G. P. Rouffaer tot adjunct-secretaris van het Instituut, met ingang van 1 Juli te voren, officieel haar beslag. De secretaris motiveerde zijn voorstel blijkens de (ongedrukte) Notulen aldus:

„Eene betere regeling van het dagelijksch toezicht op de Bibliotheken van het Instituut en het Indisch Genootschap is volstrekt noodig; de ondervinding heeft hem doen zien dat het toezicht, tot dusver door de Secretarissen van beide instellingen uitgeoefend, niet voldoende is om een ordelijken toestand te verkrijgen en, als deze eenmaal verkregen is, te bestendigen. Zijne bedoeling zou dan ook zijn dat de adjunct-secretaris hem vooral ten aanzien van alles wat de bibliotheek betreft ter zijde staat. De Secretaris vindt te meer vrijmoedigheid om tot de benoeming van den heer Rouffaer het voorstel te doen, nu deze reeds voldoende bewezen heeft voor de hem toegedachte taak bijzonder geschikt te zijn en zijne benoeming kan plaats hebben zonder bezwaar voor de geldmiddelen van het Instituut, aangezien verdere bezoldiging van den Secretaris niet wenschelijk is. Hij stelt dus voor, den Secretaris voortaan toe te kennen f 100 per jaar, bij wijze van abonnement, ter bestrijding van zijne kosten van correspondentie, en de overblijvende f 400 te bestemmen voor tractement van den heer Rouffaer, die, gaat de voorgestelde regeling door, nog f 200 ontvangen zal van het Indisch Genootschap."

Onder algemeene instemming, en met dank voor de onbaatzuchtigheid van den secretaris, wordt het voorstel aangenomen. Daar- 
mede is een band gelegd, of liever bevestigd, die voor beide partijen van verstrekkende beteekenis zou zijn.

Het is hier misschien de plaats om naar aanleiding van deze bezoldiging ook iets te zeggen over Rouffaer's geldelijke omstandigheden. Men zou licht uit het feit van zijn langdurig verblijf buitenslands de gevolgtrekking maken, dat hij over zeer ruime eigen middelen moet hebben kunnen beschikken. Niets is minder juist. Ten gevolge van zijn uiterst sobere levenswijze heeft hij kunnen bestaan van een zeer gering inkomen, en daarvan ging dan nog, zooals wij zien zullen, een gedeelte weg aan boeken, voor hem zelf of voor het Instituut. Zijn gezondheid schreef hem een dieet voor, maar wanneer hij zich gedurende de lange werkdagen op het Instituut voedde met een soort van stijfselpap, heeft hij misschien wel eens van den nood een deugd gemaakt. Hij verlangde niet naar meer, dan hem tot zijn gewone kalme leven in staat kon stellen; en toen dit op den duur moeilijk werd, heeft zijn zuster hem afdoende geholpen. Het zou zeker niet in zijn geest zijn, verder op deze financieele aangelegenheden in te gaan; doch het was toch zaak ook deze zijde van zijn persoonlijkheid, de volstrekte afwezigheid van alle geldelijke consideraties bij toch beperkte middelen, even aan te roeren.

Het eerste resultaat van zijn werkzaamheid was dan de reeds genoemde Catalogus der land- en zeekaarten. Het werk munt al dadelijk uit door de zorgvuldige beschrijving en de systematische rangschikking in rubrieken I-XXXII voor de landkaarten, en $\mathrm{A}-\mathrm{M}$ voor de zeekaarten, met registers en aanwijzingen omtrent de berging. Inderdaad toont het aan, dat Rouffaer voor dergelijk werk bij uitstek geschikt was.

Daarna kon hij, thans in officieele functie, aan de veel omvangrijker reorganisatie van de boekenverzameling beginnen. Al zijn krachten en talenten heeft hij aan die taak gewijd, vooreerst wat betreft de ordening, dan de aanvulling, en eindelijk de catalogiseering. Ook is hij dadelijk aangevangen met het aanleggen eener afzonderlijke fotoverzameling. Tal van instellingen in binnen- en buitenland wist hij te bewegen om tot ruil van uitgaven met het Instituut over te gaan; ook tal van particulieren deden op zijn voorstel - en op zijn voorgaan - belangrijke en kostbare boekgeschenken. Persoonlijk bezocht hij steeds de in aanmerking komende boekenveilingen en ook door bemiddeling van antiquarische boekhandelaren was hij steeds doende om leemten in de bibliotheek aan te vullen. Op die wijze werd de verzameling voortdurend en oordeel- 
kundig uitgebreid en gecompleteerd en is zij geworden tot de belangrijke instelling van thans. In het bijzonder verdienen vermelding de door toedoen van Rouffaer aangeschafte oude en zeldzame werken, vooral de voor de geschiedenis van het Oosten van zoo groote waarde gebleken Portugeesche en Spaansche standaardwerken, welke men in andere bibliotheken hier te lande vergeefs zal zoeken.

Dat een methodische ordening van den geheelen boekenschat met dit alles hand aan hand ging, spreekt vanzelf. Tegelijkertijd werden de werkzaamheden aangevangen voor een behoorlijken catalogus, bestemd om te worden gedrukt. Met de voorbereiding van zulk een catalogus had zich de heer J. Boudewijnse, secretaris van het Indisch Genootschap, bewerker van den catalogus dier instelling (1869), en indertijd adjunct-secretaris van het Instituut, reeds vele jaren beziggehouden, zonder evenwel zichtbare vorderingen te maken. Thans pakte Rouffaer de zaak aan, en hoewel ook hij er eenige jaren aan moest besteden, was toch in April 1902 de Catalogus voor den druk gereed. Doch eerst in 1908 is die druk beëindigd.

Ook het andere hierboven geschetste werk ten behoeve van de bibliotheek was natuurlijk niet beperkt tot het eerste optreden van Rouffaer, maar bleef jaren achtereen zijn voornaamste levenstaak. Moeilijkheden zijn hem niet bespaard gebleven - daarover straks nog iets - maar met altijd even geweldige energie en toewijding bleef hij aan den arbeid. En met welk een resultaat! Dat de chaotische boekenmassa van 1897 is geworden tot de Koloniale Bibliotheek van thans, is het werk van Rouffaer.

Wij zien daarbij allerminst voorbij, dat hij sinds April 1901 een voortreffelijken helper heeft gehad in den heer W. C. Muller, die tot de opheffing van de Indische Instelling te Delft aan de bibliotheek aldaar was werkzaam geweest. Doch met name in de eerste jaren was dat toch een ,hulp”, waarbij de leiding aan Rouffaer bleef, en juist aan die leiding heeft de heer Muller zijn uitnemende scholing op dit gebied in hoofdzaak te danken. Wij doen dus niemand te kort door de Koloniale Bibliotheek een schepping van Rouffaer te noemen.

Over het belang en over de uitstekende inrichting dezer boekerij, op koloniaal gebied verreweg de beste, en in sommige opzichten de eenige, des lands, en één van de beste van Europa, uit te wijden, daarvoor is het hier de gelegenheid niet. De bezoeker moge zich bewust zijn, wat hij zelf, en wat de beoefening der koloniale wetenschap in het algemeen, aan Rouffaer te danken heeft. Het is een 
blijvend gedenkteeken, dat hij zich hier gesticht heeft; zoo ergens, dan kan voor Rouffaer op de Koloniale Bibliotheek het bekende woord „si monumentum requiris, circumspice” gelden.

Verbazingwekkend is het nu te zien, hoe ondanks dit inspannende bibliotheekwerk reeds in 1899 de resultaten van een niet minder inspannende wetenschappelijke arbeid beginnen te verschijnen, verbazingwekkend, zelfs wanneer men moet toegeven, dat van het verwerkte materiaal heel wat gereed kan hebben gelegen. Deze wetenschappelijke arbeid beweegt zich in drie richtingen, geschiedenis, kunst en batik. Ongeveer gelijktijdig moet Rouffaer aan dat alles bezig zijn geweest. Een oproep in de courant $^{1}$ ) tot een betere organisatie ten behoeve van de Zuid-Afrikaansche republieken, gevolgd door een aansporing tot zelfbeperking in zake de komst van Kruger, kan bewijzen, dat hij ook van harte deelde in hetgeen in die dagen het geheele volk bewoog.

Wat het batikken aangaat bestond reeds in November 1898 het plan tot de uitgave van een uitgebreide studie daarover, welk plan spoedig in samenwerking met dr. H. H. Juynboll, die in opdracht der directie van 's Rijks Ethnographisch Museum aan een beschrijving der museumcollectie bezig was, tot een begin van uitvoering zou komen. Van den aanvang af heeft Rouffaer op het standpunt gestaan, dat het geheim van de afkomst der batik-kunst in VoorIndië zijn oplossing kon vinden en om het noodige materiaal te verzamelen werd in 1899 een lijst van „Vragen over de ZuidDekhansche (Tamiel'sche) was-teekenkunst en verfkunst" in het Nederlandsch en Engelsch opgesteld en rondgezonden. In April 1900 hield hij over het batikken een voordracht in het Koloniaal Museum, waarvan de inhoud in hoofdzaak (met aanvullingen) terug te vinden is in het Bulletin: een ethnologisch onderzoek en een studie van de techniek, met de om- en bijgewerkte beschrijving der in 1872 aan het Museum geschonken patronen. Hij spreekt met groote verzekerdheid, en als hij op een gegeven moment beweert, dat een aangehaald auteur ergens ",geen flauw begrip" van heeft gehad, zet een geërgerd lezer met potlood in het exemplaar der Leidsche Bibliotheek de opmerking aan den rand, dat die auteur wellicht ,een minder flauw begrip van bescheidenheid dan schrijvertje van dit artikeltje" heeft gehad. Dit onbeteekenende feit vermelden wij, omdat het toont, hoe Rouffaer door zijn wijze van betoog wel eens

1) Nieuwe Rott. Cour. van 22 Nov. 1899 en 18 Dec. 1900. 
vijanden maakte, en hoe hij klaarblijkelijk op dat oogenblik nog allerminst voor de autoriteit werd gehouden, die hij spoedig wezen zou.

Het groote werk begon inmiddels te verschijnen; de eerste afleveringen kwamen in 1900 en 1901, dan hokt het, ook omdat Rouffaer den tekst niet tijdig afleverde, tot 1904 en 1905; vervolgens heeft de uitgever het geheel moeten opgeven, eerst in 1911 is het werk door een anderen uitgever overgenomen, en in 1914 was de druk voltooid. Wij komen er te zijner tijd op terug. Onder de beslommeringen van den druk bleef Rouffaer ook op andere wijze zijn kennis van dezen tak van nijverheid productief maken; hij schrijft het desbetreffende stuk in den Gids voor de Parijsche tentoonstelling van 1900, stelt een catalogus voor de groep van weefsels, batik's en meubelen der tentoonstelling van „Oost en West” in den Haag van 1901 op, sluit die tentoonstelling met een voordracht over ikat's, enz. ${ }^{1}$ ), en maakt het volgend jaar nogmaals een catalogus voor een tentoonstelling van weefsels en batik's te Rotterdam; ten slotte zou datzelfde ook nog eens geschieden in 1906 voor een tentoonstelling te Krefeld.

De bemoeienis met Oost en West en het zitting nemen in een der commissies van die vereeniging maakte, dat Rouffaer vanzelf betrokken werd in het door eenige leden dier commissie, belangstellend in Indische kunst en kunstnijverheid, genomen initiatief tot stichting der Naamlooze Vennootschap Boeatan. Aan de voorbereiding heeft hij een werkzaam aandeel gehad, en toen de vennootschap in 1903 tot stand kwam, trad hij op als eerste secretaris van den Raad van Beheer. Voor dat belangeloos verrichte werk, drie jaar lang waargenomen, heeft hij veel tijd en moeite, doorgaans achter de schermen, over gehad; hij had echter ook de voldoening Boeatan door de eerste moeielijke jaren heen te helpen komen.

Toen het batik-boek was aangevangen, lag ook reeds een andere lijvige studie zoo goed als gereed. De uitnoodiging, om voor de Encyclopaedie van Nederlandsch-Indië een artikel te schrijven over de beeldende kunst van Indië, was gaarne aanvaard, maar het stuk, dat in September 1898 reeds in hoofdzaak klaar was, bleek veel te uitgebreid voor het doel en moest dus belangrijk worden ingekort. Vandaar dat het in werkelijkheid in het tweede deel der Encyclo-

1) Deze tentoonstelling gaf aanleiding tot een eenigszins oppervlakkige en in de feiten meermalen onjuiste Karakterschets van G. P. Rouffaer, in de Hollandsche Revue van 1901, p. $641-655$. 
paedie verschenen artikel „Kunst (beeldende)” in verschillende opzichten slechts een uittreksel is van het origineel, terwijl voor allerlei bewijzen en bijzonderheden verwezen wordt naar de uitgebreidere studie, die de auteur toen voornemens was elders het licht te doen zien. Dit is echter nooit geschied en dat is zeer te betreuren; dit degelijke en rijk-gedocumenteerde stuk zou een grondslag hebben kunnen vormen voor verder kunsthistorisch onderzoek, welke het gekortwiekte Encyclopaedie-artikel met al zijn beweringen, waarvan het bewijs weggelaten werd, onmogelijk kon verschaffen.

Het oorspronkelijk artikel is in vier groote afdeelingen gesplitst, die achtereenvolgens de algemeen-Indonesische kunst, de uitgestorven Hindoe-kunst, de levende kunst der Balineezen en de kunst in de vroegere Hindoesche en heidensche streken na de komst van den Islam behandelen. De volgorde is behouden gebleven, maar hoeveel merkwaardigs blijkt verdwenen. De eerste afdeeling bijvoorbeeld bespreekt in de eerste plaats den huizenbouw en weet daarin drie typen te onderscheiden: de woning met cirkelrond grondvlak, de meest archaische, die van de Nicobaren tot de Fidji-eilanden voorkomt; de paalwoning met rechthoekig grondvlak, verklaard als Indonesisch en afkomstig uit Achter-Indië; het rechthoekig gebouw op den grond, dat juist met de Hindoe's uit Voor-Indië is gekomen. Dit alles leidt, ook door de geconstateerde mengingstypen, tot allergewichtigste gevolgtrekkingen. Vervolgens komt de sierkunst aan de beurt; dat alles te zamen beslaat in het manuscript 42 bladzijden folio. In de Encyclopaedie vindt men dit in een paar alinea's afgedaan, zonder dat ook maar in het minst blijkt, wat er al zoo geschrapt is moeten worden. $\mathrm{Nu}$ is er in de tweede en derde afdeeling wat minder weggelaten, doch in de laatste weer zooveel te meer; met elkaar vullen die oorspronkelijk nog 122 bladzijden. In het stuk over de Hindoekunst, aan welke sedertdien zooveel aandacht gewijd is, staat natuurlijk nog al wat, dat door later onderzoek achterhaald is, doch als in het laatste stuk wordt beredeneerd, hoe hetgeen in Mohammedaansche streken aan kunstmotieven leeft, van niet-Mohammedaanschen oorsprong is, doch een Hindoeschen tint heeft, gelegd op Indonesischen grond, dan is er bij de besproken details en de aangevoerde bewijzen allerlei, dat op het oogenblik nog even frisch en nieuw klinkt als dertig jaar geleden.

Het Encyclopaedie-artikel doet Rouffaer kennen als iemand, die zich in de Indische kunst heeft ingewerkt en daaromtrent verrassend inzicht vertoont. Het oorspronkelijk stuk zou hem, als het was ge- 
publiceerd, de plaats hebben verzekerd van algemeen erkende, beste autoriteit op het gebied der Indische kunst.

De studies van historischen aard zijn te vinden in de Bijdragen. Het zou natuurlijk geen nut hebben als wij daarvan, zooals bij ongepubliceerd materiaal is geschied, een eenigszins uitvoerige inhoudsopgave gingen samenstellen; ieder, die er zich voor interesseert, kan de stukken zelf raadplegen. Wel is het misschien gewenscht van de voornaamste - voor de kleinere kan verwezen worden naar de bibliographie - de strekking en de waarde te bespreken.

Het eerste groote artikel in de Bijdragen van 1899 (waarvan meer dan de helft door Rouffaer is vol geschreven) draagt den algemeenen titel „Het tijdperk van godsdienstovergang (1400-1600) in den Maleischen Archipel” met den ondertitel „1e Bijdrage: Wanneer is Madjapahit gevallen?" De aanleiding is ook in dit geval de Encyclopaedie geweest, en wel het verzoek om een artikeltje van een pagina te schrijven over Madjapahit; in tegenstelling tot de Beeldende Kunst is thans de uitvoerige studie wel gepubliceerd. De auteur deelt mede zijn aandacht al geruimen tijd op het tijdperk van de komst en overwinning van den Islam te hebben geconcentreerd, en stelt latere artikelen over het Mohammedaansch worden van West-Java, over een Portugeesch rapport van 1514, en over opkomst en overwicht van Malaka in het uitzicht. Alleen van dit laatste is iets gekomen, en dat pas meer dan dertig jaar later.

Een Fransch beoordeelaar heeft eens van Rouffaer gezegd: „le don de la composition lui manque", en dat gebrek is in een artikel als dit, waar het op een bepaald betoog aankomt, wel voelbaar. Met zijn verschillende soorten van vette letters, spatieeringen, cursiveeringen en zijn lange noten, laat het zich niet prettig lezen, en dan heeft het nog een Appendix, die langer is dan het artikel zelf. Maar de methode is voortreffelijk. Nadat de vroeger bekende data omtrent de Madjapahitsche geschiedenis zijn opgesomd, volgen systematisch in chronologische volgorde de nadere gegevens, waarop de redeneering zal berusten, en wordt - wel eens iets te wijdloopig en met een wat reclame-achtig vet gedrukt „En nu komt het afdoende bewijs" - de betrouwbaarheid en de consequentie van die gegevens in het licht gesteld. Het resultaat is, dat een lapsus calami bij Barros wordt geconstateerd en dientengevolge de val van Madjapahit tusschen 1516 en 1521 wordt gesteld. De Appendix behandelt dan verder uitvoerig de Portugeesche geschiedschrijvers voor deze periode, hun persoonlijkheid en hun verschillende edities. 
$\mathrm{Nu}$ behoeft men het met de redeneering ten slotte niet eens te zijn, en inderdaad is later betoogd, dat door een verschrijving bij een anderen auteur dan Barros aan te nemen, de heele conclusie weer op losse schroeven komt te staan; niet twijfelachtig echter is de waarde van het bijeengebrachte materiaal, dat men vindt gerangschikt en gewaardeerd op een wijze, zooals alleen iemand van Rouffaer's speurzin en zaakkennis dat vermocht; ook uit den Appendix kan men tallooze te voren niet bekende of tevoren niet op de juiste waarde geschatte bijzonderheden putten. Het artikel geeft ons Rouffaer als wetenschappelijk schrijver in de typische eigenaardigheden, deugden en gebreken, die hem steeds zijn eigen gebleven.

De „1e Bijdrage” was nauwelijks van de pers, of nog in hetzelfde jaar werd een $2 \mathrm{e}$ Bijdrage vour de geschiedenis van het tijdperk van godsdienstovergang op stapel gezet. Zij liep over „Petroleum in Pĕrlak van 1511-1682; en Sumatra's Noorden als zetel van den Islam, $\pm 1250-1400$." De eerste helft van wat de titel beloofde was toen bijzonder actueel, want juist was met andere landschappen ook Peureula en onderhoorigheden voor mijnbouwkundig onderzoek aan de rechthebbende vragers uitgegeven, en in December zou de Koninklijke haar exploratie aanvangen. Rouffaer herinnert aan het oudste moderne bericht over de Pĕrlaksche petroleum, dat var. Bogaert uit 1875, en gaat dan verder: „Voor de meesten, zoo niet allen, zal het verrassend zijn in het volgende te vernemen, hoe de faam dezer Atjeh'sche, speciaal Perrlak'sche petroleum niets nieuws is. Integendeel men zal merken hoe reeds in 1511, bij den zeetocht naar de stad Malaka die haar verovering zou teweeg brengen, de Portugeezen op zéér eigenaardige wijze kennis maakten met dit product; hoe daarna de opgaven van juiste herkomst dezer aardolie weifelen, waarbij eerst het Pidië'sche (Pedir'sche) op den voorgrond treedt, doch daarna, en terecht, het Pathè'sche (Pasei'sche) met nadruk wordt genoemd; hoe dan Camões, in zijn in 1572 voor 't eerst verschenen koloniaal heldendicht „De Loezíeaden” (Os Lusiadas), deze "Sumatraansche oliebron" zoowaar bezingt! En hoe, bij het sluiten der 16e eeuw, de eindeeuw van Portugal's overzeesche grootheid, een zeer deskundig, immers te Malaka geboren en getogen Portugeesch halfbloed, in 1599 bepaaldelijk Perrlak zal aanwijzen als de plek waar deze oliebron gevonden werd, en dat met toevoeging van eenige bijzonderheden, die op treffende wijze herinneren aan de rapporten van Bogaert cum suis van bijna 3 eeuwen later!"

Men ziet hieruit eenigszins, wat de bedoeling van het stuk is. 
De bespreking van de bovenbedoelde oudste berichten, te vinden bij Barros, is in vrijwel geheel afgewerkten staat in handschrift aanwezig ; daarbij blijken ook de nog oudere gegevens over Noord-Sumatra uitvoerig te zijn behandeld, zoodat het wemelt van allerlei belangrijke opmerkingen van historischen en geographischen aard, die ons zeer ver van de petroleum afbrengen. Doch wanneer Rouffaer aan de eerste bladzijde over Camões toe is, heeft hij het er verder bij gelaten. Het is dan blijkens een aanteekening op den omslag 1907 geworden, dus er is aan dit artikel bij stukjes en beetjes gewerkt. Tot afmaken is de auteur ook later nooit gekomen, hoewel hij het stuk belangrijk genoeg achtte, om het nog in 1915 aan een deskundigen vriend in Indië ter lezing te zenden.

Ziedaar dan een schaduwzijde van Rouffaer's werkwijze: het te veel tegelijk aanpakken en telkens in ieder bijzonder geval toch het uiterste aan nauwkeurigheid en volledigheid van gegevens willen produceeren, heeft noodzakelijkerwijze geleid tot dè onmogelijkheid om alles tot een goed einde te brengen. Zoo ligt er veel onvoltooid, waarvan niet altijd precies valt na te gaan, wanneer het op touw is gezet. Onder de manuscripten van wat grooter omvang vermelden wij een Voorwoord bij de voorgenomen uitgave van het Pěpakěm Tjarbon van 1768, verder een no. I van „Vorstenlandsche Studiën”, welk eerste artikel loopt over de ontwikkeling der Anggĕr Agĕng, en dan een 1e Bijdrage voor een toekomstig Nederlandsch Koloniaal Woordenboek (,Hobson-Jobson”). Van dit laatste is het misschien niet zoo erg te betreuren, dat er niet verder van gekomen is, want taalkunde, en bepaaldelijk etymologie, behoorde niet tot de sterkste zijden van Rouffaer's wetenschap. Een buitengewoon lijvig, maar niettemin onvoltooid „Nader Verslag omtrent de onderlinge verhouding der teksten van Barbosa's Livro van 1516" zou misschien, als het afgedrukt was, den gewonen lezer der Bijdragen wat hebben afgeschrikt, doch bevat een uitermate nauwgezet onderzoek naar de tekstgeschiedenis van het beroemde werk, zoodat het ongetwijfeld een groot verlies is, dat dit alles niet tot zijn recht is gekomen en de jongste uitgever van Barbosa er niet van heeft kunnen profiteeren.

Het tweede groote artikel, dat wél gedrukt is, en meer dan 250 bladzijden in de Bijdragen van 1899 vult, tracht de vraag te beantwoorden: „Waar kwamen de raadselachtige moetisalah's (aggrikralen) in de Timor-groep oorspronkelijk van daan?" Het is een studie van pijnlijke, men zou bijna zeggen overdreven, uitvoerigheid, 
maar het onderwerp wordt dan ook inderdaad uitgeput. Alle mogelijke oude en jonge berichten over deze kralen, niet alleen in de Timor-groep maar ook in andere deelen der wereld, worden kritisch belicht; van een vroegere poging tot oplossing van het raadsel wordt aangetoond dat zij de kwestie heeft verduisterd in plaats van verhelderd, en dan komt Rouffaer's eigen oplossing, aan de hand alweer van een van die Portugeesche bronnen, waarmede hij zoo vertrouwd was, Barbosa, en diens beschrijving van de kornalijnen kralen van Cambay. Dat is de plaats van herkomst der eerste, antieke, moetisalah's van den Timor-Archipel, en over die kornalijnen krijgen we dan alle verdere gegevens, de eeuwen door. Of liever, dat zouden wij gekregen hebben, want met 1516 is het voorloopig uit en dan staat er "slot volgt."

Ook dit slot is nimmer gevolgd. Eenige bladzijden in handschrift toonen aan, dat een eerste aanloop tot het schrijven van het vervolg is genomen, maar bij die enkele bladzijden is het gebleven. Wij moeten tevreden zijn met wat er is, en mogen misschien constateeren, dat het zóó ook, al welletjes is. Doch het zacht protest van den lezer tegen den omvang en de compositie van het artikel zal hem geen oogenblik doen vergeten, welk een massa feiten hij heeft geleerd of in een ander licht gezien, en welke een onschatbaren dienst Rouffaer aan het verder onderzoek naar deze kwestie heeft bewezen.

Nog een derde artikel dient in dit verband even vermeld te worden; het staat in de Bijdragen van 1900 en draagt den bescheiden titel: „Een paar aanvullingen over bronzen keteltrommen in Ned.Indië". Het is kort en overzichtelijk, maar daarom niet minder belangrijk, waar het de aandacht vestigt op nog onbekende exemplaren, en op de oudste mededeeling op dit gebied, die van niemand minder dan Rumphius is; ook worden eenige conclusies geformuleerd over den vermoedelijken weg, waarlangs deze trommen in den Archipel zijn gekomen. Een later artikel, over nog zulk een door Rumphius beschreven dondertrom, heeft het weer niet verder dan een paar bladzijden ter inleiding kunnen brengen.

Het jaar 1901 bracht Rouffaer nog meer dan tevoren in aanraking met de Indische oudheden; het is het jaar van de oprichting der ambtelijke Commissie tot oudheidkundig onderzoek op Java en Madoera, onder voorzitterschap van Brandes, en het is tevens het jaar der instelling in Nederland van een Commissie van Bijstand ten behoeve van dat onderzoek, met Rouffaer als secretaris.

Van de stappen, die gedaan moesten worden en de moeilijkheden 
die overwonnen moesten worden om tot dit toezicht van gouvernementswege op de Indische oudheden te geraken, heeft Rouffaer later een en ander verteld ${ }^{1}$ ); hij zelf had er toe medegewerkt door het opstellen van een nota over inrichting en werkwijze van den Britsch-Indischen Archaeological Survey. Toen de desbetreffende post goed en wel op de begrooting stond, noodigde de Minister van Koloniën het Instituuts-bestuur uit, om zijn medewerking te verleenen voor de publicatie der eventueele resultaten van het onderzoek, en om de regeering bij voorkomende gelegenheid van advies te dienen. Ten einde op zijn beurt deskundig te worden voorgelicht benoemde het Bestuur een Commissie van Bijstand, onder presidium van prof. Kern. Het werk dier Commissie kwam grootendeels neer op den secretaris. Er was een voortdurende correspondentie, met allerlei autoriteiten en voorts, of ficieel en ondershands, met Brandes in Indië, vooral met betrekking tot de publicaties der Indische Commissie; en zoo heeft Rouffaer veel kunnen doen om het oudheidkundig onderzoek behoorlijk op gang te brengen. Nadat overeengekomen was, dat de driemaandelijksche rapporten van Brandes in Indië zouden worden gepubliceerd, doch de groote monographieën, die op het programma stonden, in Nederland, was het ook weer Rouffaer, aan wien de verzorging van de uitgave der eerste monographie, over Tjandi Djago, ten deel viel.

Juist vóór de instelling der Commissie had hij nog een's duidelijk getoond, hoezeer hij de man was, om de Javaansche Hindoe-kunst te verstaan. Het artikel over "Monumentale kunst op Java” in de Gids van 1901 dient zich aan als een bespreking van Von Saher's „De versierende kunsten in Nederlandsch Oost-Indië”, maar gaat in belangrijkheid verre uit boven het werk dat er aanleiding toe gaf. Immers na een inleiding over de beoefening der wetenschappen in Indië in het algemeen, en van de oudheidkunde in het bijzonder, wordt de klassieke kunst van Midden-Java, de kunst van Prambanan, Diëng en Baraboedoer, in zijn geestelijk karakter verklaard en de nauwe samenhang aangewezen tusschen de centrale idee van het Boeddhisme en de edele Boeddhistische kunst. Baraboedoer in het bijzonder, hoewel Saher er voorbijgeloopen schijnt, levert stof voor een hooggestemde beschouwing, over de zoo diep gevoelde plaatsing der Boeddha-figuren, die den bezoeker van aanschouwen tot gelooven voeren, en over het architectonische meesterstuk van de reeksen der

1) In het Voorbericht der Djago-monographie. 
opstijgende poortgebouwen. Treffend wordt het verschil met Grieksche kunstopvatting in het licht gesteld; treffend uiteengezet hoe deze reliefkunst de apotheose geeft van de Indische plastiek. Zóó was er nog nooit over Baraboedoer geschreven. Het is Rouffaer, die ons het eerst Baraboedoer heeft doen zien als werk van hoogste kunst, juist omdat het een werk van hoogste wijding was. Het artikel, dat tot zulk een beschouwing de oogen opende, is voor de waardeering der Hindoe-Javaansche kunst van niet licht te overschatten belang geweest.

Aan de voorbereiding van de uitgave der monographie over Djago zijn, naar uit de gevoerde briefwisseling blijkt, heel wat beslommeringen verbonden geweest, ook omdat het no. 1 van een serie zou worden, en dus allerlei beslissingen moesten worden genomen, die ook voor de toekomst bindend zouden zijn. Reeds einde 1902 deelde hij op een vergadering van het Aardrijkskundig Genootschap een en ander over het te verwachten boek mede. Behalve het Voorbericht met het relaas der tot stand koming van het oudheidkundig onderzoek, heeft Rouffaer ook een uitvoerig Litteratuur-overzicht samengesteld. Het werk aan deze uitgave heeft grootendeels in het jaar 1903 plaats gehad; het deel is in 1904 verschenen. Spoedig zou de Commissie van Bijstand over nog andere gewichtige zaken te beraadslagen krijgen: de plannen tot restauratie van Baraboedoer, en na den plotselingen dood van Brandes de wijze, waarop diens werk zou worden voortgezet. Aan alle adviezen, die over deze zaken werden uitgebracht, heeft Rouffaer zijn, dikwijls overwegend, aandeel gehad.

Wanneer wij nu nog even naar het jaar 1901 terugkeeren, dan vinden wij er nog een ander belangrijk werk van zijn hand, het nauwkeurige Register op de eerste 50 deelen (1853-1899) van de Bijdragen, welks nut niet aangetoond behoeft te worden. Terzelfder tijd werd ook weder bibliographische arbeid ter hand genomen door de samenstelling, tezamen met W. C. Muller, van de „Eerste proeve van een Rumphius-bibliographie", welke deel uitmaakt van het Rumphius-gedenkboek uit 1902, en niet minder dan 56 dicht bedrukte groote folio-bladzijden inneemt.

Afzonderlijke vermelding verdient ook een voortzetting der historische studiën van de Vorstenlanden, waartoe de uitgave in de Bijdragen van 1902 van een Beknopte beschrijving van het Hof van Soerakarta in 1824, door J. W. Winter, aanleiding gaf. Een voorwoord geeft eenige bijzonderheden over den schrijver en zijn om- 
standigheden, doch vooral merkwaardig zijn de noten, en wel speciaal no. 56,58 en 61 , waarin zeer uitvoerig - de enkele noot 56 is bijna $50 \mathrm{blz}$. lang - gehandeld wordt over de rechtsinstellingen, en naar gewoonte met rijke documentatie, ook uit archiefstukken, de verhouding van Soerambi, Pradata, Balemangoe en Soesoehoenan's Raad wordt besproken. Het feit, dat er natuurlijk ook gehandeld wordt over de Anggĕr Agĕng heeft misschien tengevolge gehad, dat de bovengenoemde Vorstenlandsche Studie over dat onderwerp verder in de pen is gebleven. In 1903 plaatst Rouffaer in het Album Kern een bijdrage over een duistere plaats in de Portugeesche geschiedschrijving inzake den politieken toestand van Java tijdens Padjang; hij is daar dus weer in het tijdperk van godsdienstovergang bezig. Aan het slot van die bijdrage wordt de vraag gesteld en beantwoord, waar precies toch eigenlijk Padjang heeft gelegen. Rouffaer wist dat door eigen onderzoek ter plaatse in 1889; er is een opschrijfboekje met terreinschetsen van zijn hand bewaard, die eveneens betrekking hebben op den kraton van Kartasoera. Na de kwestie in het Album-Kern weder aangepakt te hebben, wilde hij een nader artikel over de beide genoemde kratons doen verschijnen, dat volgens een later plan deel zou uitmaken van een nog uitgebreider studie, waarin ook Pasar Gĕḍe, Kĕrta en Plered betrokken zouden worden. Ook dit artikel, dat juist tengevolge van het terrein-onderzoek zooveel nieuws had kunnen opleveren, is bij een paar bladzijden inleiding blijven steken. Voorloopige kaarten zijn echter aanwezig, en kunnen misschien bij een latere wederopvatting van deze studie nog dienst doen.

Het stuk over de kratons was bestemd voor de Bijdragen. De redactie van dit tijdschrift berust, zooals men weet, bij den secretaris van het Instituut; klaarblijkelijk heeft in deze jaren Rouffaer als adjunct-secretaris de redactioneele werkzaamheden verricht. Het is althans gemakkelijk zijn hand te herkennen in de ongeteekende noten der redactie, die aan enkele artikelen zijn toegevoegd. Ook ziet men hem in en na dezen tijd blijk geven van belangstelling op weer een nieuw gebied, dat tot dusver zijn aandacht nog niet zoo had getrokken, namelijk Suriname.

Had nu de secretaris Kielstra de zorg voor de Bijdragen gaarne aan zijn bekwamen adjunct overgelaten, in andere opzichten bleef de verhouding tusschen de beide functionarissen niet zoo aangenaam, als zij in den aanvang was geweest. Daarvoor waren er verschillende redenen. Eén ervan is, dat het Instituut, aan de Heerengracht wat 
nauw behuisd, omzag naar een betere woning, die het dan ook in April 1903 heeft gevonden in Van Galenstraat 14. Dat plan ging in hoofdzaak uit van den heer Kielstra, en Rouffaer was er hevig tegen. Waarom is moeielijk te begrijpen, althans op het oogenblik, nu men weet, hoe uitstekend het denkbeeld is geweest, en hoe goed het Instituut deze vijf en twintig jaar in zijn nieuwe behuizing geïnstalleerd is geweest. Rouffaer echter vreesde, dat de verandering geen verbetering zou zijn; zijn bibliotheek was nu eenmaal goed geordend opgesteld, en hij was van nature conservatief en gehecht aan het eenmaal bestaande.

Een tweede reden tot verwijdering gaf de langzame druk van den Catalogus. Zooals wij reeds vermeldden, heeft deze volle zes jaren geduurd! Dit is geheel de schuld, of van een andere zijde beschouwd de verdienste, van Rouffaer. In zijn streven om zoo nauwkeurig en voortreffelijk mogelijk werk te leveren, vroeg hij voortdurend nieuwe revisies en bracht telkens weer wijzigingen aan, die den drukker tot vertwijfeling brachten. Ook hield de vertraagde druk verband met het feit, dat Rouffaer steeds bezig bleef met het aanvullen der bibliotheek, en als er een nieuwe aanwinst in het vooruitzicht was, welke nog in den Catalogus zou kunnen worden opgenomen, het afdrukken van een bepaald vel aanhield. Dat den heer Kielstra als verantwoordelijken secretaris dit in zijn oogen volstrekt onnoodige getalm onaangenaam moest zijn, spreekt vanzelf.

Het voornaamste punt van verschil betrof echter juist de daareven genoemde aanvulling van de bibliotheek. Over eventueelen aankoop had de secretaris te beslissen, doch de adjunct-secretaris, voortvarend als hij was en overtuigd van de noodzakelijkheid om bepaalde werken te bezitten, deed wel eens boekbestellingen voor het Instituut op eigen gelegenheid. Dat gaf natuurlijk wrijving, in het bijzonder als de secretaris die noodzakelijkheid niet kon inzien. Het gevolg was, dat Rouffaer, die tegen het uitdrukkelijk bevel van zijn chef met zulke aankoopen niet verder kon gaan, langs anderen weg toch zijn doel wist te bereiken, door hetzij het werk zelf te koopen en aan het Instituut te schenken, hetzij een beroep te doen op de mildheid van anderen, die zijn gevoelens deelden, of, wat misschien nog wel meer het geval is geweest, het niet over zich konden verkrijgen de hartgrondige smeekbeden van Rouffaer - bij zulk een betoog kon hij zelfs tot tranen geroerd zijn - af te slaan. Zoo kwam het boek er dan toch, en dat was nu natuurlijk weer niet prettig voor den secretaris, die nu eenmaal de baas was, en verklaard had het nut D1. 84. 
van het werk niet in te zien. De heer Kielstra had van zijn standpunt natuurlijk gelijk, maar Rouffaer vond dat standpunt bekrompen en schroomde niet deze opinie ook aan derden kenbaar te maken, en dat verscherpte het conflict. Gedreven door zijn vaste overtuiging, dat de Koloniale Bibliotheek op haar speciale gebied zoo rijk mogelijk moest zijn, heeft Rouffaer ondanks alles zijn pogingen voortgezet, maar de oneenigheid heeft hem veel verdriet bezorgd. Ook in andere opzichten is hij gedurende deze jaren, zonder ooit een op den voorgrond tredende rol te spelen in het Instituut en zonder ooit een bestuursvergadering bij te wonen, door middel van zijn besprekingen met bestuursleden dikwijls een drijvende kracht geweest.

Nog één bemoeienis uit de eerste helft zijner Haagsche jaren verdient vermelding, die met de volkskunst en inlandsche kunstnijverheid. Reeds in 1901 deed hij in de Indische Gids een pleidooi hooren voor een technisch-artistiek onderzoek der Indonesische volkskunst, waaraan nog maar zoo bitter weinig aandacht was geschonken; zulk een onderzoek zou eerst in een gedeelte van den Archipel met sterk sprekend karakter op nijverheids- en kunstgebied moeten beginnen; na publiceering van de resultaten kon de kring worden verwijd; dan moesten plannen worden gemaakt tot instandhouding, bevordering en ontwikkeling van inlandsche kunst en nijverheid: onze kennis zou de welvaart bevorderen en op den duur zou voor de voortirengselen zeker een markt te scheppen zijn. Men ziet, hoe hier een band gelegd wordt tusschen het kunsthistorisch onderzoek, en de bevordering der kunstnijverheid als gevolg daarvan.

In 1904 kon Rouffaer in De Gids met ingenomenheid melding maken van een studie, die geheel in zijn geest geschreven was, wat het eerste deel van zijn programma, het onderzoek naar nog levende volkskunst betrof : het werk van J. A. Loebèr over Timoreesch snijwerk en ornament. De wijze, waarop Loebèr's voornaamste materiaal is ondergebracht, in 's Rijks Ethnographisch Museum te Leiden ${ }^{\mathbf{1}}$ ), doet een beschouwing volgen over het toen juist verschenen rapport der Commissie van Advies, die zich had moeten uitspreken over de vraag, of dit Museum te Leiden moest blijven. Rouffaer stelt zich, de zaak van nationaal standpunt beziende, aan de zijde van het ééne

1) Een uitlating in Rouffaer's artikel aangaande de houding van den Directeur van genoemd museum tegenover den heer Loebèr heeft een protest-brochure, Fatsoen en eerlijkheid, door dr. J. D. E. Schmeltz (Leiden 1904), een antwoord van Rouffaer in de Nieuwe Rott. Cour. van 6 Maart 1904 en een nieuw ingezonden stuk van dr. Schmeltz op 8 Maart tengevolge gehad. 
lid der Commissie( den heer IJzerman), die zich voor overbrenging naar Amsterdam had uitgesproken. Bij één onderdeel van Rouffaer's betoog kan men er zich rekenschap van geven, hoezeer in de laatste vijf-en-twintig jaar de gangbare opinie der deskundigen is gewijzigd. Het is waar hij uitroept dat, waar ook het museum moge komen, men alles moet tentoonstellen, alles uitstallen, en alléén het minderwaardige in dépôt houden. Deze opvatting zal thans wel door geen museum-autoriteit meer onderschreven worden; voor het overige is er allerlei in hetgeen van de Leidsche museum-toestanden wordt gezegd, dat helaas eerst thans iets van zijn actualiteit begint te verliezen.

Eveneens in 1904 heeft Rouffaer tezamen met J. Habbema een rapport ingediend over de antwoorden, die op een prijsvraag van het Koloniaal Museum te Haarlem waren ingekomen inzake het sirihgebruik en datzelfde jaar gaf hem nog op andere wijze gelegenheid om zijn inzicht, zoowel in de nijverheid als in de agrarische toestanden, productief te maken. In verband met het renteloos voorschot, dat minister Idenburg op de begrooting van 1904 aan Indië wilde verleenen, had de Kamer een afgerond plan bij afzonderlijk wetsontwerp verlangd, en daartoe consulteerde de minister een drietal kenners van Indië, in het vaderland aanwezig. Eén dier drie, mr. C. Th. van Deventer, verzocht onder meer de medewerking van Rouffaer, en deze schreef dientengevolge vijf stukken, te weten over den Agrarischen rechtstoestand der inlandsche bevolking op Java en Madoera, den handel, de scheepvaart, de visscherij en vischteelt, de voornaamste industrieën der inlandsche bevolking. De vier laatstgenoemde zijn afgedrukt in het in 1904 verschenen „Overzicht van den economischen toestand der inlandsche bevolking op Java en Madoera", dat over de industrieën in den vorm van een afzonderlijk Aanhangsel; aan het eerste heeft $\mathrm{mr}$. Van Deventer slechts eenige gegevens ontleend ${ }^{1}$ ).

Van dit rapport over den agrarischen rechtstoestand heeft de auteur zelf gebruik kunnen maken, toen hij het volgend jaar het artikel „Vorstenlanden” voor de Encyclopaedie opstelde; evenals bij Beeldende Kunst het geval was, verwijst dus ook dit artikel telkens naar een ongepubliceerde grootere studie. Deze zelf bleef door allerlei omstandigheden ongedrukt tot 1918; toen Rouffaer er van

1) Ook in 1905 heeft Rouffaer op verzoek van Van Deventer nog een nota over de uitzwerming der Javanen opgesteld, toen in November de kwestie der Javaansche emigratie naar de Buitenbezittingen in de Tweede Kamer in behandeling kwam. 
had afgezien voor den tweeden druk der Encyclopaedie het artikel Vorstenlanden om te werken en het agrarisch deel daarvan zou worden behandeld door prof. Van Vollenhoveñ, welke een andere opvatting was toegedaan, stelde de schrijver er prijs op, dat de druk niet langer zou worden uitgesteld. Men zal het rapport dus vinden in de Bijdragen van 1918, met enkele toevoegingen, en gevolgd als een soort van tegengif, zegt Rouffaer zelf - door een AntiRouffaer van prof. Van Vollenhoven. Een inleiding geeft, als fundament van het geheele betoog, het bewijs dat de souverein op Java eigenaar is van den grond, en daaruit worden dan de agrarische rechtstoestanden van de Vorstenlanden, als meest ouderwetsche, van de Gouvernementslanden, die onder vreemde invloeden zijn gekomen, en van de bijzondere categorieën der pĕrdikan-desa's en particuliere landerijen verder verklaard.

Van de overige stukken is dat over de industrieën het belangrijkste. Nagegaan wordt, wat er op dat gebied nog aanwezig is en wel achtereenvolgens wat betreft de textiel-nijverheid, de houtbewerking (huis- en scheepsbouw), het vlechtwerk en de vezelstoffenbewerking, steen- en pottenbakkers- en steenhouwerswerk, metaalbewerking, lederbewerking. In het algemeen geldt, dat de oude technieken zóó gewijzigd en verbeterd moeten worden, dat zij de concurrentie kunnen doorstaan. Aanbevolen wordt bijvoorbeeld ook de oprichting van stoomspinnerijen en witweverijen, het geven van deskundig onderricht in vlechttechniek, ambachtsonderwijs in goud- en zilversmidswerk en in de smeedkunst; maar in de eerste plaats is het toch steeds verbetering van techniek en verruiming van markt, die er op aan komt. Met handel, scheepvaart en visscherij is het mutatis mutandis hetzelfde gesteld.

Ook in een paar Encyclopaedie-artikelen van 1902 kan men wat van Rouffaer's inzichten over de inlandsche nijverheid vinden. De grootste en meest doorwrochte bijdragen heeft de Encyclopaedie van dezen merkwaardigen, en niet altijd gemakkelijken, medewerker echter eerst verkregen voor haar vierde deel, hetwelk in 1905 is verschenen. Daar zijn er bij van een belang en een beteekenis, die hetgeen men zoo gewoonlijk in een Encyclopaedie-artikel vindt, verre overtreft. Trouwens ook elders heeft Rouffaer te kennen gegeven, dat hij de opvatting, als zou zulk een artikel een samenvatting moeten zijn en geen nieuw onderzoek mogen geven, allerminst deelde.

Over het artikel „Vorstenlanden” spraken wij reeds even. Het is voor velen een openbaring, voor ieder een verrassing geweest, en is 
reeds dadelijk opvallend door zijn lengte, 132 kolommen, maar meer nog door zijn inhoud. In zijn verschillende rubrieken, waarvan die over grondgebied, vorsten, inlandsch bestuur, landelijk stelsel, landverhuur, rechtswezen de voornaamste zijn, biedt het allerlei tot dusver onbekende bijzonderheden, vrucht van Rouffaer's veeljarige studie ter plaatse. Het artikel geeft in gecomprimeerden vorm de uitkomsten van dat veelomvattend onderzoek. Ook later is Rouffaer bezig gebleven met zijn aandacht aan dit onderwerp te wijden; in 1906 vroeg en verkreeg hij van het departement van Koloniën verlof tot het raadplegen van daar berustende rapporten.

Van de andere Encyclopaedie-artikelen, wier volledige lijst men in de bibliographie kan vinden, vermelden wij hier dat over Valentijn, in samenwerking met den heer Muller - wij herinneren ons hoe Valentijn ook reeds in Indië Rouffaer's aandacht had getrokken -, en dat over vaartuigen, ook met allerlei zaken, die vroeger niemand had opgemerkt; hier leende de zeeofficier Coops voor technische kwesties de behulpzame hand. Dan over de interessante Tĕnggĕreezen: de daaromtrent bestaande uitgebreide litteratuur was door niemand nog goed samengevat; Rouffaer is de eerste die in deze hinderlijke leemte tracht te voorzien, tevens alles bijbrengend, wat eigen kennis van Javaansche toestanden hem aan de hand deed. Ook met „Tijdrekening” heeft hij een zeer nuttig werk verricht.

Ten slotte heeft ook hetgeen is samengebracht onder ,Tochten (oudste ontdekkings-)" bijzonder de aandacht getrokken. Het behandelt den tijd vóór de Portugeezen, en vermeldt in chronologische volgorde alle Hindoesche, Grieksche (in Grieksche letters!), Chineesche, Arabische, Italiaansche berichten, ook enkele inlandsche, als hoedanig Pararaton en Nāgarakṛtāgama fungeeren. Men ziet hieruit, hoever het begrip ontdekkingstocht geacht wordt zich uit te strekken, en zal ook zonder dat begrijpen, dat de auteur telkens de gelegenheid aangrijpt om aan de mededeelingen zijner bronnen eigen, dikwijls gewaagde, bijna altijd overweging verdienende, conclusies vast te knoopen. Het artikel behelst dan ook heel wat meer, dan een relaas van ontdekkingstochten; het is een beredeneerd overzicht van alles wat, uit andere bron dan de inscripties, over den Archipel vóór 1500 bekend was. Gegevens van dezen aard kunnen het uitgangspunt vormen van veel onbewezen en onbewijsbare gissingen. Rouffaer is daar nooit voor teruggeschrikt, ook later niet, want hij heeft zich nog veel met dergelijke bronnen beziggehouden. Hij heeft inderdaad dikwijls onderstellingen geopperd, die door de vakgeleerden op goede 
gronden werden afgewezen, tot zijn ongehuichelde teleurstelling. Hij heeft echter ook in heel veel gevallen door een soort intuitie het juiste inzicht gehad; veelal is voor een zijner gevolgtrekkingen, die toen zij geopperd werd als een zuivere hypothese in de lucht hing, later het bewijsmateriaal aan het licht gekomen. Maar ook waar hij faalde, heeft hij door het verrassende zijner voorstellen anderen tot nader onderzoek geprikkeld en door een aanvankelijken misslag toch tot de ontdekking der waarheid geleid. In zulke gevallen was hij de eerste, om zich daar hartelijk over te verheugen; eigen roem heeft hij nooit gezocht.

Het jaar 1906 zette hij in met het schrijven van een Voorbericht bij Nieuwenkamp's Bali en Lombok, waarvan het eerste deel in dat jaar verscheen, en gaf daarin aardige bijzonderheden over kunstenaars in Indië, met een beschouwing over het karakter der kunst van Bali. De aanraking met dezen kunstenaar, dien hij ook persoonlijk nader trad, heeft tot een blijvende vriendschap en een blijvende bewondering geleid. Iets later in dat jaar komen de Bijdragen met een artikel, welks eigenaardige inhoud al uit den titel blijkt: „De Hindostansche oorsprong van het ,negenvoudig" Sultans-zegel van Atjeh, aangetoond o.a. door een merkwaardig Hindostansch schilderijtje van ca. 1700. Tevens onder herkenning eener teekening van Rembrandt". De kenner der Hollandsche kunst treedt hier dus ook weer even te voorschijn. Het schilderijtje geeft het portret van den GrootMogol Aurangzeb tusschen de in een kring daaromheen geplaatste medaillons zijner voorvaderen; op dezelfde wijze blijkt het grootzegel der Mogols ingericht, maar dan met de namen in plaats van de beeltenissen, en het Atjèhsche sultanszegel is niets anders dan een navolging van dat der groote heerschers van Indië. Door middel van de portretten kan de vorst, die op een teekening van Rembrandt (in het Britsch Museum) op zijn troonschabel zit, en door Sarre als Akbar was geïndentifieerd, worden herkend als Jahāngir. Het volgend jaar gaf de Atjèh-kenner bij uitnemendheid, prof. Snouck Hurgronje, nog eenige aanvullingen op wat hij Rouffaer's ,helder betoog" noemde ${ }^{1}$ ).

In den loop van 1906 werd aan Rouffaer - die inmiddels verhuisd was en thans Stadhouderslaan 14 woonde - nog een nieuwe functie opgedragen naast die aan het Instituut, namelijk het secretariaat der redactie van het Tijdschrift van het Aardrijkskundig

1) In Bijdr. 7: VI p. 52-55. 
Genootschap. Voorzitter dier redactie werd gelijktijdig de heer J. F. Niermeyer, terwijl het Genootschap zelf werd gepresideerd door den heer J. W. IJzerman, met wien Rouffaer reeds sedert zijn eerste werkzaamheid bij het Instituut bekend was. In Niermeyer heeft Rouffaer, ondanks alle erkenning van diens goede eigenschappen, te veel de zwakke stee gezien om met hem tot een bepaalde vriendschap te geraken; voor den heer IJzerman daarentegen koesterde hij een waardeering, die de aanvang geweest is van een vriendschapsband. Ook op wetenschappelijk gebied zouden beiden eenige jaren later in zeer nauwe relatie treden.

's Genootschaps tijdschrift toont van stonde aan de werkzaamheid van den nieuwen secretaris. Het eerste, dat hij er in zet, een bespreking van de inaugureele oraties der Delftsche hoogleeraren Molengraaff en Van Bemmelen, is merkwaardig, omdat Rouffaer er als oud-student in het mijningenieurs-vak spreekt en op ietwat ironischen toon oude herinneringen aan zijn studietijd ophaalt; hij kan daar nu klaarblijkelijk met kalmte op terugzien, het oude zeer is weggesleten. Wat hij verder in de eerstvolgende jaargangen schrijft, zijn hoofdzakelijk korte berichten en besprekingen; van de grootere artikelen is één, over den naam Seran voor Zuidwest Nieuw-Guinea, van historisch-geografischen aard, en ontleent weer een tot dusver niet op de juiste waarde geschat gegeven aan Rumphius; het andere behandelt de vroegere opvaarten van de Mambèråmo, en bepleit de noodzakelijkheid eener verdere verkenning dezer merkwaardige rivier.

Beide hebben dus betrekking op Nieuw-Guinea, en datzelfde is met een groot deel der kleinere stukken het geval. Daar is reden voor: het Aardrijkskundig Genootschap hield zich in die jaren veel met deze streken bezig en had er de Zuidwest NieuwGuinea-expeditie heen gedirigeerd, waarvan de resultaten nog altijd het licht moesten zien. Ook met de verzorging van deze uitgave werd Rouffaer belast, en zoo moest hij zich vanzelf met allerlei kwesties gaan bemoeien. Het werk, in 1906 reeds aangekondigd, verscheen eerst in Mei 1908; Rouffaer schreef er een Voorrede bij, en van hem is ook het voorstel om den hoogsten top naar den eersten ontdekker van dit gebergte Carstensz-top te noemen.

Doordat hij zich meer dan vroeger op aardrijkskundig terrein bewoog, is er sprake van geweest hem te bestemmen voor den nieuwen leerstoel in de aardrijkskunde te Utrecht, waarvoor hij zich echter niet geschikt achtte, zoodat dit professoraat ten slotte door Nier- 
meyer is bezet. Later echter is hij een zeer ernstig candidaat geweest voor het buitengewoon professoraat in de ethnographie, eveneens te Utrecht, en dit was inderdaad geheel overeenkomstig zijn wenschen. Toen hij begin 1909 naar Indië vertrok, was dat met het vooruitzicht, om na terugkomst dit nieuwe ambt te zullen aanvaarden. Aangezien er, toen het zoover was, van dit vooruitzicht niets gekomen is, heeft het geen nut er hier verder bij stil te staan. Het is moeilijk zich Rouffaer voor te stellen in een dergelijken werkkring, die hem ongetwijfeld veel teleurstelling zou hebben berokkend.

Inmiddels naderde het groote werk, dat hij voor het Instituut had ondernomen, zijn voltooiïng: in September 1908 verscheen de Catalogus der Koloniale Bibliotheek. Over de verdiensten van dit kostelijk werk van meer dan 1000 bladzijden, behoeft hier zeker niet gesproken te worden. Door de duidelijke en overzichtelijke beschrijving der boekwerken, de systematische indeeling en de voortreffelijke registers is het werk buitengewoon gemakkelijk in het gebruik en heeft het de rijke bibliotheek eerst recht voor ieder belangstellende toegankelijk gemaakt. Enkele door de practijk wenschelijk gebleken kleine wijzigingen zijn door den heer Muller in latere supplementen toegepast, doch overigens is de doelmatige methode gehandhaafd. Men kan altijd direct zien, wat 'er over een bepaald onderwerp aanwezig is, en heeft doordat de registers niet alleen namen maar ook verkorte boektitels vermelden, ook dadelijk een gewenscht werk voor oogen. Op dezen voortreffelijken Catalogus konden Rouffaer en Muller - terecht staan beider namen op het titelblad — met reden trotsch zijn.

In het Voorwoord geeft Rouffaer ook aan dr. Kielstra alle eer, als dengeen die het denkbeeld van de vereeniging der bibliotheken van Instituut en Indisch Genootschap heeft verwezenlijkt, en onder wiens secretariaat de verzameling voortdurend is uitgebreid om haar te maken tot de koloniale bibliotheek hier te lande, de onvoorwaardelijk beste instelling van dien aard. Van het voorloopig bereiken van dit doel legde de Catalogus getuigenis af, en met het beëindigen van dit werk meende Rouffaer dat ook de taak, waarvoor hij tot adjunct-secretaris was benoemd, was afgeloopen. Dadelijk nadat de Catalogus het licht had gezien, vroeg hij dan ook ontslag, tegen het einde van het jaar.

Er was echter nog een tweede, zeker niet minder klemmende reden, die hem tot dit besluit noopte, en diezelfde reden deed hem einde 1908 eveneens het secretariaat van het Tijdschrift Aardr. 
Genootsch. neerleggen, onder bijzondere dankbetuiging aan zijn medewerkers dr. Easton en den heer Craandijk. Het was het allengs tot vasten vorm gekomen plan om voor de tweede maal een groote reis naar Indië te ondernemen. Ook aan een derde functie moest die reis een einde maken, het bestuurslidmaatschap van de in Maart van ditzelfde jaar opgerichte Linschoten-Vereeniging. Het ligt voor de hand, dat Rouffaer aan het tot stand komen van die nuttige vereeniging, wier doel, het uitgeven van zeldzame of onuitgegeven Nederlandsche zee- en landreizen en landbeschrijvingen, zoo geheel in zijn lijn lag, met de grootste sympathie had medegewerkt.

Het Instituutsbestuur verleende het ontslag natuurlijk op de meest eervolle wijze, en gaf in de laatste vergadering van dat jaar bij monde van zijn voorzitter prof. Kern nog eens uiting aan zijn gevoelens van dankbaarheid voor al hetgeen Rouffaer én aan de boekerij én aan den catalogus én in andere opzichten had gedaan. Zijnerzijds liet Rouffaer zich inschrijven als donateur, en overhandigde op deze zelfde laatste vergadering nog eenige belangrijke boekgeschenken ten behoeve der hem zoo dierbare bibliotheek ${ }^{1}$ ).

Het plan voor een Indische reis, ditmaal in hoofdzaak naar de Buitenbezittingen, was reeds in den loop van 1907 tot rijpheid gekomen, doch daar het thans uitgesloten was, dat Rouffaer uit eigen middelen die reis zou bekostigen, was de verwezenlijking afhankelijk van hulp van elders, in de eerste plaats van de regeering. Ter voorbereiding hadden in September van dat jaar de eerste besprekingen plaats met prof. Snouck Hurgronje en den heer Groeneveldt; beiden beloofden gaarne hun ondersteuning, hoewel de heer Snouck, Rouffaer kennende, er dadelijk bijvoegde, dat hij het boek, hetwelk Rouffaer zich als resultaat van de reis dacht, slechts zag ,in een ver nevelig verschiet". De uitkomst heeft geleerd, hoe juist dit gezien was!

De volgende stap was, dat in Juli $1908 \mathrm{mr}$. Van Deventer het plan voorlegde aan minister Idenburg en bij dezen een welwillend oor vond; alleen kon de regeering niet rechtstreeks een opdracht geven, maar gaf zij er de voorkeur aan, het initiatief van een ander lichaam financieel te steunen. Dat andere lichaam werd, dank zij de tusschenkomst van den heer IJzerman, het Aardrijkskundig Genootschap. Ieder, die Rouffaer en zijn werk kende, bevorderde gaarne diens voornemens, en zoo werden reeds bij een der nota's van wijziging voor de begrooting 1909 de eerste gelden aangevraagd. Rouffaer

1) Zie Notulen 1908 (in Bijdr. 7: VIII) p. VIII en XI sq. 
zelf had inmiddels, naast voorbereiding in Nederland, ook een bezoek aan Londen in Augustus reeds eenigermate aan zijn plannen dienstbaar gemaakt.

Het doel van de reis wordt in een voor den minister bestemde nota door den aanvrager zelf aldus omschreven: „De heer G. P. Rouffaer gevoelt sedert langen tijd de behoefte om verschillende ethnografische gegevens door hem en anderen verzameld en hoofdzakelijk betrekking hebbende tot den N.-I. Archipel in een systematisch verband samen te vatten. Hij zou zich daarbij vooral willen laten leiden door hetgeen de geschiedenis omtrent vroeger bestaan hebbende toestanden en de ontwikkeling daarvan tot de thans bestaande leert. Ten einde nu echter verschillende gegevens omtrent thans bestaande toestanden aan de werkelijkheid te toetsen en wellicht geheel nieuwe gegevens te verzamelen, acht hij het ondernemen van een studiereis naar N.-Indië noodzakelijk, waarbij hij dan zijn aandacht vooral zou willen richten op verschillende streken der buitenbezittingen." Het vooruitzicht te Utrecht werd ter aanbeveling eveneens aangevoerd. De reis zou twee jaar duren, en zich ook uitstrekken tot de Filippijnen, Britsch-Borneo, Portugeesch-Timor en het schiereiland Malaka. De kosten waren begroot op f 11.000 , waarvan het Genootschap f 5000 en de regeering de rest op zich nam.

Daar de verdere voorbereiding vlot van stapel liep, daargelaten eenige uit zijn correspondentie blijkende zenuwachtigheid van Rouffaer, kon deze in April 1909 de reis aanvaarden. Voor het zoover was, had hij aan nog één laatste taak de hand gelegd, die hem bij tusschenpoozen gedurende de afgeloopen drie jaren na aan het hart had gelegen, het persklaar maken der archaeologische nalatenschap van dr. Brandes.

Dadelijk na diens overlijden in Juni 1905 waren de stukken, die deze geleerde voor toekomstige monographieën had gereed gemaakt en die betrekking hadden op de Tjandi Singasari en op de Wolkentooneelen van Panataran, naar Nederland gestuurd; de Commissie van Bijstand had tot den druk besloten, de verzorging daarvan aan haar secretaris opgedragen, en tevens gaarne diens aanbod aanvaard om het nieuwe deel te doen voorafgaan door een Herdenking van Brandes van zijn hand. De eigenaardige werkwijze van Rouffaer, die ook hier steeds wijzigde en toevoegde, en het feit dat hij voor allerlei details overleg met Indië noodig vond, heeft een bedenkelijke vertraging veroorzaakt, zoodat het werk eerst aanvang 1909 is verschenen. 
Van de beide stukken, waaruit de monographie bestaat, behoefde dat over Panataran slechts van enkele noten voorzien te worden; aan de beschrijving van Singasari daarentegen heeft Rouffaer, behalve zijn noten, meer tekst toegevoegd dan het oorspronkelijke manuscript bedroeg; pag. 50-116 zijn geheel van zijn hand, en behelzen een zeer uitvoerige bibliographie en niet minder uitgebreide beschouwingen over de beteekenis van bepaalde tempelresten en beelden, en over de lotgevallen van het bekende, thans te Berlijn staande beeld van den Bodhisattwa Mañjuçrī. Het is de eerste maal, dat Rouffaer zich op zuiver oudheidkundig terrein beweegt, al komt hier natuurlijk ook veel historisch onderzoek bij te pas. In dat laatste is hij het gelukkigst, meer dan in zijn archaeologische hypothesen, waarbij zijn zelfverzekerdheid niet altijd de zwakte der argumenten kan bedekken. De waarde van dit werk ligt dan ook minder in de eigenlijke conclusies dan in de nauwkeurige en scherpzinnige wijze, waarop het materiaal bijeengezocht en bearbeid is. Schrijver dezes, die in dezen zelfden tijd zich voorbereidde op het overnemen van Brandes' taak, mag hier wel even getuigen, hoeveel hij van Rouffaer geleerd heeft, toen deze bij alle drukte van zijn aanstaand vertrek, toch gelegenheid vond om onder het bewerken dezer hoofdstukken ook den jongen vakgenoot op de meest onbekrompen wijze mede te deelen van zijn kennis en van zijn enthousiasme.

Over de Herdenking van Brandes spraken wij reeds even. Door personen, die Brandes na hebben gestaan, is wel gezegd, dat Rouffaer er niet altijd in geslaagd is bij de beschrijving van diens levensomstandigheden den juisten toon te treffen. Hoe het ook zij, de oprechte waardeering en even oprechte kritiek, die uit het opstel spreken, doen aangenaam aan, en het behoeft nauwelijks gezegd te worden, dat het feitenmateriaal aan nauwkeurigheid en volledigheid niets te wenschen overlaat. Zoo geeft het stuk, ondanks mogelijke gebreken, van Brandes' wetenschappelijke ontwikkeling een helder beeld, in het bijzonder van zijn archaeologische werkzaamheid. De buitengewone beteekenis van Brandes op dit gebied, door Rouffaer gevoeld toen anderen nog twijfelden, komt hier ten volle tot haar recht.

In Maart 1909 werden zoowel Tjandi Singasari als de Herdenking afgesloten. Dadelijk daarop vertrok hij, en na nog een dag of drie in Venetië te hebben doorgebracht, scheepte hij zich den 15den April te Genua in op het stoomschip Rembrandt. 
IV.

Het van te voren opgestelde reisplan, dat Rouffaer op zijn tweede Indische reis dacht uit te voeren, is bewaard gebleven. Het luidt als volgt.

In Mei 1909, na een kort verblijf te Batavia, naar de Lampongs, overland naar Palembang, en eveneens overland naar Bengkoelen. Dan in Juni een tweede doorkruising van Sumatra, van Padang naar Siak, en in Augustus een derde, van Deli naar Baroes of Singkĕl. Vervolgens in September langs Tapa Toean en Meulaboh naar Koeta Radja, overland naar Pedir, en in October naar Batavia terug. In November Java door en van Soerabaja naar Makassar, van waar uit in December de Saleier en Boeton bezocht zouden worden. Voor 1910 stond in Januari een overlandreis naar Pare-Pare op het programma, en voorts zou, eveneens overland, van Donggala via het Poso-meer naar Mapane worden getrokken; in Maart moesten Gorontalo, de overlandreis vandaar naar Kwandang, en Menado volgen. Dan kwamen in Mei Ternate, Ambon en Banda aan de beurt, in Juni Dobo en Měraukĕ, c.q. Fakfak, in Augustus de Tĕnimbĕr en Zuidwester-eilanden, benevens Timor Dilly. Vervolgens in October Timor Koepang; via Ende en Bima zou Laboean Hadji op Lombck bereikt worden, waarna in November zoowel Lombok als Zuid-Bali dwars zouden worden doorgetrokken, zoodat over Banjoewangi de terugreis naar Soerabaja kon plaats hebben. Daarna Borneo; in December Bandjarmasin en Koetei, in Januari 1911 Pontianak en een verdere reis via Broenai naar Manila. Van de Filippijnen kon in Maart over Singapore en Penang naar Oleh-leh worden teruggekeerd en vandaar zou in April de boot naar Nederland worden opgevangen. Gelijk men ziet, een keurig plan, volgens hetwelk inderdaad alle gewenschte streken binnen het geraamde tijdsverloop van twee jaar bezocht konden zijn.

Hoe geheel anders is dat alles uitgekomen!

Van het verloop der reis zijn wij helaas niet op de hoogte door het voorgenomen groote werk, waarin het ter plaatse waargenomene had moeten worden samengevat met de vruchten van historische studie. Doch zijn oude gewoonte getrouw, is Rouffaer dadelijk aanteekeningen gaan maken in dagboek-vorm, en hoewel van de 30 daartoe aangeschafte boekjes nog geen vierde volgeschreven is, zijn wij toch voor die gedeelten van de reis, waarbij hij tijd en gelegenheid voor deze notities had, over zijn doen en laten nauwkeurig 
ingelicht. Enkele stukken konden uit klad-aanteekeningen aangevuld worden; andere echter ontbreken. Vandaar dat het hieronder volgend relaas van Rouffaer's reis een ietwat onevenwichtig karakter moet dragen, afhankelijk als het is van de telkens aanwezige gegevens.

De zeereis zelf had het gewone verloop; zij eindigde - eerste, kort voor het vertrek uit Europa vastgestelde afwijking van het programma - voorloopig te Singapore, waar het schip op $7 \mathrm{Mei}$ arriveerde. Het eerste wat Rouffaer er aanteekent, als hij van de Rembrandt de stad inwandelt, is ,diepe indruk kranigheid Chin. kunst," gevolgd door de grootschheid der reede. Na een paar dagen ter orienteering, vangt op 9 Mei de studie aan. Niet alleen het museum, waar Hanitsch op dat oogenblik conservator is, maar alle mogelijke andere zaken worden eveneens opgenomen; allerlei personen worden opgezocht, of op andere wijze in den kring van belangstelling getrokken, en juist als vijf-en-twintig jaar geleden krijgen wij naar aanleiding daarvan allerlei rake typeeringen van personen en toestanden. $\mathrm{Er}$ is natuurlijk ook veel bij die aanteekeningen, dat niets met studie te maken heeft, en men krijgt al dadelijk het idee: te veel. Uit niets blijkt dat er een plan van onderzoek was, en bepaalde zaken in het bijzonder nagegaan moesten worden. Alles, wat hem interessant voorkomt, laat hij, men zou bijna zeggen passief, ware het niet dat hij zich zoo uitermate weinig passief gedraagt, op zich inwerken. Informatie in den ruimsten zin, maar eigenlijk niet veel meer.

Te Singapore zelf wordt nog al wat studie gemaakt in den Botanischen tuin; ook heeft een uitstapje naar Djohor Bahru plaats. Op 18 Mei vertrekt Rouffaer naar Malaka en is daar dan eenige dagen aan het opnemen en aanteekenen, vooral op oudheidkundig gebied. Den 24sten vertrekt hij weer, gaat via Kuala Lumpur naar Ipoh, bezoekt een tinmijn, verblijft een paar dagen te Taiping, waar het Perak-museum en de heer Wilkinson de punten van aantrekking zijn, gaat dan een rubberonderneming bekijken, en bereikt den 30sten Penang, waar hij dr. Lüring spreekt. Op den terugweg wordt het museum te Kuala Lumpur bezocht, waar, evenals te Taiping, vooral de weefsels de aandacht vragen; op 3 Juni is Rouffaer te Singapore, en den volgenden dag, vier weken na zijn aankomst, reist hij verder naar Batavia.

Voor hij scheep gaat, teekent hij aan een pakket boeken voor de Koloniale Bibliotheek te hebben in orde gemaakt, en aan den heer 
Muller te hebben geschreven. Dat zal nog heel dikwijls in de memoranda voorkomen: met grooten ijver is Rouffaer gedurende de geheele reis de belangen der bibliotheek blijven behartigen. Voor aankoop was hem een bescheiden crediet toegestaan; maar van veel meer belang was, dat hij door zijn persoonlijke tusschenkomst telkens weer personen en instellingen er toe wist te bewegen om de bibliotheek door boekgeschenken te verrijken.

Op 6 Juni wordt Batavia bereikt. Wij hebben vroeger de eerste indrukken van den jongen tourist van 1885 vermeld; als tegenhanger zij thans eveneens opgenomen, wat de ongeveer vijftigjarige Rouffaer van 1909 van zijn eersten dag te boek stelde:

,Zondag 6 Juni. 'S morgens 6 uur aan stuurboord licht Zuidwachter dwars in regenbui, waarna dat van Edam volgt; dan Alkmaar, Enkhuizen en Leiden, waarna haven Tandjoeng-Prioek achter wolkgordijn in zicht komt. Om 7 uur instoomen. Eerste indruk: handel Batavia tot $h$. Singapore als 1 : 20; daargelaten de op orders wachtende stoomschepen buiten de hoofden voor anker liggend, niet veel stoombooten aan Westkade, en een enkele aan oostelijke kolenkade; geen Chineezen haast op de kade te zien, alleen inlanders en zéér gemengde Europeanen. Door douane-onderzoek langzaamheid bij 't aan wal komen, en gezeur; modderpoelen, door den regen, om en bij het station; minder soort 1e klasse-wagens, vergeleken met de F. M. S. Railways; besliste onzindelijkheid der W.C. tusschen de afdeeling der 1e en 2e klasse in de wagon; hinderlijke belachelijkheid van het Plakkaat-Pendek, dat ik niet eerbiedig, en dat aangeplakt is in eenige exx. in Holl. en Fransch in elke coupé. Onder regen naar Batavia S. S.-station, voor 't eerst daar in sado langs vrij slechten Molenvliet-weg, komen in Hôtel des Indes, vinden van allerlei brieven. Ontmoeten mijning. Moerman. 'S namiddags eerste wandeling op weg naar Van Ronkel: Molenvliet smaller geworden dan herinnering meende, mooie roode kleur der. Tjiliwoeng-muren tusschen Noordwijk en Rijswijk vervangen (sinds wanneer?) door weinig sprekend grauw, de wegen - zelfs om het Koningsplein - onvoldoende, niet-mooi, de tamarinde-boomen die de wegen omzoomen zeer liefelijk, hier en daar intiem, doch zonder het grootsche der angsana-dreven te Penang en hier en daar te Malaka, het „Wilhelmina-park” beslist onvoldoende onderhouden, het Koningsplein tè groot door zijn afmetingen, een ,gaping" in het stadsverband in stee van een plein, alleen gered door de vreedzaam daarop weidende kudde koeien, zoo de gedachte wek- 
kend van een meent; alleen de koepellijn van de Willemskerk spreekt daarin, het zinken dak van het "Station Weltevreden” zegt niets, de aardige roode daken van een 3-tal gebouwtjes benoorden daarvan (nieuwe R. K. Broederschool) doen aardig. Daarna 1e bezoek bij Van Ronkel”, enz:

Den volgenden dag hebben verdere bezoeken plaats en woont Rouffaer een Directie-vergadering van het Bataviaasch Genootschap bij, waar hij al dadelijk eenige mededeelingen doet en wenschen uit, o.a. om het Genootschap in nauwe relatie te brengen met de Straits Branch der Royal Asiatic Society. Op die vergadering maakt hij ook kennis met een man, van wien hij gedurende en na zijn reis nog veel vriendschap zou ondervinden, den heer J. P. Moquette, die de numismatische verzameling van het Museum beheerde, en tevens in het bezit was van een eigen ethnographische collectie, waaruit Rouffaer spoedig de koedii's zou beschrijven.

Een paar dagen later is het Topographische Inrichting, die zijn groote belangstelling gaande maakt, vooral omdat hij er veel geheel anders (en beter) vindt dan hij had vermoed; een aantal bezoeken aan deze inrichting zijn nog gevolgd en hebben aanleiding gegeven tot een beschrijving voor het Aardrijkskundig Genootschap, gelijk ook andere stukjes in dezen tijd werden op schrift gesteld. Bij één daarvan, over het voorkomen van oudheden volgens vroegere berichten in Sěkadau (West-Borneo) had hij de voldoening nadere gegevens van den controleur ter plaatse uit te lokken ${ }^{1}$ ).

Ook in den lithograaf der Topographische Inrichting, den heer J. W. Teillers, begroette Rouffaer een hem dadelijk zeer sympathiek persoon. Voorloopig intusschen was hij het meest intiem met den landsarchivaris, dr. F. de Haan, met wien hij geregeld, dikwijls dagelijks, van gedachten wisselde en in wiens onderzoekingen (het groote werk Priangan was toen juist voor den druk gereed) hij zeer deelde. Ook persoonlijk genoot hij zeer van de gesprekken met De Haan, evenals van de gemeenschappelijke fietstochten - Rouffaer had zijn eigen karretje van eigenaardig $Z$ weedsch model meegebracht - in de omstreken.

Voor het overige bemerken wij weinig van eigenlijke studie, maar zooveel te meer van gesprekken met alle mogelijke menschen, doorgaans menschen van beteekenis. Een gaarne behandeld onderwerp is Nieuw-Guinea: de heeren Lorentz en Van Nouhuys waren toen

1) J. Bouman in Tijdschr, Bat. Gen. 53 (1911) p. 314-325. 
juist te Batavia, vóór de tweede Lorentz-expeditie; maar ook andere zaken zijn welkom. Mannen als Vissering, Van Rees, De Graaff worden aangehaald, en dan, na diens aankomst te Batavia, ook Colijn. Met groote liberaliteit geeft die laatste aan Rouffaer gelegenheid om vrij te werken in allerlei hem dienstige stukken. Het zou natuurlijk onbescheiden zijn, hier Rouffaer's oordeel over bekende, thans nog levende, personen te vermelden, en dat is jammer genoeg, want, hoewel hij kritisch keek, boosaardig is hij nergens, en zijn korte karakteristieken van bijvoorbeeld de menschen, die hij op een bestuurs- of commissie-vergadering meemaakte, zijn meesterlijk.

Bij gesprekken alleen bleef het niet; al heel gauw treft, hoe Rouffaer waar hij het noodig vindt, raadgevingen en voorstellen niet achterhoudt. Op het Museum komt hij lof en blaam over de Directie-leden uiten; hij is het, die als Hanitsch in Batavia is, hem 's Genootschaps bibliotheek vertoont, en hij is het ook, die een poosje later met den betrokken ingenieur B. O. W. confereert over de vraag, welke kleur de raamkozijnen van het Museum moeten krijgen. Op dezelfde manier gaat het elders. Men kan begrijpen, dat dit dikwijls kwaad bloed zette en niet ieder inzag, dat Rouffaer steeds het belang der zaak op het oog had, nooit zich uit persoonlijke overwegingen mengde in zaken, die hem eigenlijk niet aangingen. Met dat al, wat men zijn bemoeizucht noemde, werd hem al heel gauw nagehouden: ook in het Indië van 1909 was de meneer uit Holland, die eens zou komen vertellen hoe het moest, niet populair.

Bij al deze bemoeienis blijft de studie wat op den achtergrond; maar Rouffaer woekert met zijn tijd en vindt toch telkens weer gelegenheid om stukken op gouvernementsbureaux in te zien, en op het Museum te werken. Eerst is het de ethnographische afdeeling daar; maar wat hij noteert van een hem bij uitstek bekend onderwerp, de weefsels, blijft steken na luttele regels. Dan wordt het vooral de nalatenschap van Brandes, die hem aantrekt, in het bijzonder de epigraphische, en hetgeen op het gebied der inscripties sinds Brandes' dood gedaan, en meer nog verzuimd was. Hoe langer hoe meer nemen deze oudheidkundige beslommeringen hem in beslag. Aardig is het, in verband met zijn latere behandeling van dit onderwerp, aangeteekend te vinden, hoe hij op een gegeven moment tot de ontdekking komt, dat het oude Malayu het moderne Djambi moet zijn. Over deze en soortgelijke vondsten komen dan weer mededeelingen in een vergadering van het Bataviaasch Genootschap. 
Eind Juli wordt een andere zaak aangepakt, weder op voor Rouffaer karakteristieke wijze. Op zekeren ochtend neemt hij kennis van de stukken over de beraamde Engelsche expeditie naar NieuwGuinea, en deze treffen hem diep; in een onderhoud met den heer Colijn spreekt hij uit, dat het onze plicht is vóór de Engelschen den doorsteek te doen, desnoods door twee expedities, respectievelijk van Havik-eiland en Mímika uit. Colijn suggereert den GouverneurGeneraal te gaan spreken, die zoo iets stellig aan Christoffel zal opdragen. Zoo gezegd, zoo gedaan. Denzelfden avond is Rouffaer te Buitenzorg, en den volgenden ochtend, na een genotvolle wandeling, ten paleize. Het gesprek met Van Heutsz verdient in Rouffaer's eigen woorden weergegeven te worden.

„Na eerste inleidende woorden gaat de G.-G., die er uitstekend uitziet, met nuchtere helderheid spreken over o.a. bouwen te Batavia om van Koningsplein een waardig centrum te maken van goede Regeeringsgebouwen, waarbij op het Batav. Museum een verdieping op kon; evenals Singapore, zegt hij, moet Batavia flinke gebouwen krijgen, daarbij zelf verwijzend naar ,zijn” Kota-Radja-bouw, waarbij een opzichter van den Waterstaat wel kon o.a. met gootconstructie op de huizen, wat de ingenieurs niet konden. Zeggen hoe hij de begrooting voor 1910 expres had belast met diverse belangrijke reorganisaties, o.a. van geneeskundigen dienst en aankoop lijn Batavia-Buitenzorg, om het zijn opvolger makkelijk te maken, ,als nu Idenburg, zooals ik hoop, mijn opvolger zal worden". Spreken over de $4 \%$ hoofdelijken omslag op Sumatra's Westkust, die hij als maximum wilde, terwijl Min. Fock om doctrinaire redenen niet meer wilde dan $2 \%$. Dan spreken over wegen die men met auto b.v. op Sumatra's Oostkust nu kan gaan, makkelijk tot het Toba-meer, en dat Cremer met 2 auto's van Medan naar Padang wil. Ik: ,het zal nog wel lang duren vóór men in een auto op Nieuw-Guinea van Noord- naar Zuidkust zal kunnen gaan.” De G.-G. : ,ja, NieuwGuinea...”. $\mathrm{Nu}$ is dit op het tapijt, en noemt hij zelf even Christoffel. Ik pak de kans, kan den G.-G. op de kaart het gewenschte traject Havikeiland-Carstenstop-Mímikamond wijzen, en zeggen dat dit een prachtige opdracht voor Christoffel zou zijn. Het psychologisch oogenblik is er geweest; mijn taak is gedaan. Even daarop vraagt de G.-G. mij ten eten; ik accepteer gaarne, en neem afscheid. Vredig en verheugd ga ik naar huis."

Bij het diner geeft de Gouverneur-Generaal aan Rouffaer dan nog gelegenheid om openlijk over den zeer wenschelijken doortocht, het

DI. 84. 
eerst door Nederlanders, te spreken. Zoo is de zaak op touw gezet, en het boekje komt nog dikwijls op deze expeditie terug, waarvan, zooals men weet, ten slotte niet Christoffel, maar Franssen Herderschée de man is geweest.

Den volgenden dag wordt Treub bezocht en de terugreis aanvaard. Maar een week later is er al weer een andere aanleiding om plotseling Batavia te verlaten; de wenschelijkheid namelijk om nog iets van de Pasar Malĕm te Soerabaja te zien. Rouffaer logeert daar bij mr. A. Paets tot Gansoyen, voor wien hij een introductie heeft, en die een voortreffelijk gastheer blijkt. Samen gaan zij het oude Ngampel bekijken en bezoeken zij Leran, Grěsik en Giri, terwijl Rouffaer met zijn gastheer ook een andere zaak bespreekt, die hem na aan het hart ligt, het oprichten van gemeentelijke bibliotheken in de hoofdplaatsen. Op den terugweg naar Batavia wordt Bandoeng aangedaan, om te Lembang het door de goede zorgen van den controleur Kern keurig verzorgde graf van Junghuhn te bezoeken, en dan zijn stukje daarover voor het Gedenkboek te schrijven.

Van deze reis komt Rouffaer met spierpijn terug, en ook in andere opzichten gaat hij zich bij tusschenpoozen wat minder lekker voelen. Toch worden tochtjes gemaakt. bijvoorbeeld naar Depok en later naar Toegoe, en wordt het werk op het Museum voortgezet, thans bijna uitsluitend in de transcriptie-bundels van Brandes. In de Directie-vergaderingen van September en October wordt daar allerlei over verteld; in het bijzonder is hij bezig aan een (in de Notulen opgenomen) lijst der beschreven steenen van het Genootschap, en een nooit afgekomen uitvoerigen inventaris. Met De Haan wordt afgesproken samen een geschiedenis van Batavia te schrijven, waarvan Rouffaer het stuk vóór 1650 voor zijn rekening zal nemen. Met de ongesteldheid hangt een depressie samen, die hem doet neerschrijven, dat hij den indruk krijgt van de onvolkomenheid van eigen werk. Daarnevens is er heel veel in de leiding van het Bataviaasch Genootschap, dat hem niet bevalt; hij spreekt zelfs van een „droeven toestand”. Daaromtrent overlegt hij dan verder met den toenmaligen voorzitter, F. A. Liefrinck, en bij een van die gelegenheden komt hij tot een uiting, die op zijn Indisch werk een merkwaardig licht werpt. Het relaas van een gesprek met Liefrinck eindigt aldus: ,ik ten slotte hem sterk trachten op te wekken om zijn Boek over Bali te schrijven, waarbij ik hem toevertrouw dat mijn persoonlijke neigingen gingen in andere dan koloniale richting, maar 
dat ik, ziende dat andere werkers daar ontbraken en ikzelve krachtig kon mede-arbeiden, dààrom die richting had gekozen."

Men moet daarbij bedenken, dat deze uiting niet zoo maar een opwelling in den loop van een gesprek is, maar later rustig in het memorandum is neergeschreven. Wij behoeven dus niet te twijfelen, dat zóó inderdaad Rouffaer tegenover zijn Indisch werk stond: hij deed het als een plicht, uit verantwoordelijkheidsgevoel, omdat het gebeuren moest, en hij begreep het te kunnen. Het geeft eenigszins een sleutel voor zijn wijze van optreden in allerlei heterogene Indische belangen: hij voelde het als een deel van de zelfopgèlegde taak, om waar hij meende een beter inzicht te hebben, dat inzicht ook te doen gelden.

De herdenkingsdag van Junghuhn, 26 October, brengt hem opnieuw een paar dagen naar Bandoeng voor een kranslegging en een toespraak; hij blijft wat ziekig en De Haan vindt hem niet meer ,bouillant”. Inmiddels wordt hij in beslag genomen door de zorg, om een Indische Junghuhn-Commissie in elkaar te krijgen, als blijkt, dat uit Nederland daarvoor niet gezorgd is; dat geeft allerlei beslommering, maar hij pakt weer energiek aan en de Commissie komt er. Van Buitenzorg uit verschaft een tocht naar Tjiampea hem een ,heerlijken ongebroken dag van poëzie op Java”; voor de natuur is hij nog even gevoelig als vroeger, en de meest verschillende soorten natuur weten hem te treffen.

Te Batavia wordt het oudheidkundig werk weer opgevat, en het is niet te zeggen, waardoor dat aan een eind zou zijn gekomen hij liep rond met het idee zich een half jaar aan de nalatenschapBrandes te wijden - wanneer er op 14 November niet iets bijzonders was gebeurd, in den vorm van een bezoek van majoor P. J. Spruijt, die hem vertelt van zijn opdracht om in begin 1910 de registratie uit te voeren van de kleine Timor-eilanden, en wellicht ook de Zuidwester-eilanden (dat hing nog van de op handen zijnde nieuwe administratieve indeeling af). Rouffaer voelt' dadelijk grooten lust met hem mee te gaan en spreekt daarover; de heer Spruijt moedigt hem warm aan, en ten slotte spreekt men af, twee dagen later nog eens samen te komen. Op dien datum lezen wij: ,De kogel gaat door de kerk: ik spreek met Spruijt af, dat ik mééga naar de kleine Timor-eilanden, en geef hem daar de hand op." Het vertrek zal begin Januari plaats hebben.

$\mathrm{Er}$ is dus niet zoo heel veel tijd over; allerlei voorbereiding wordt getroffen, het oudheidkundig werk voorloopig afgesloten, nog even 
een klacht gelanceerd over het onvoldoend kaartenmaken bij de Topographische Inrichting, enzoovoort. Op 18 December woont Rouffaer den historischen dag bij der overdracht van het Gouverneur-Generaalschap door Van Heutsz aan Idenburg; ook daarvan is een levendige beschrijving bewaard gebleven. Den eersten Kerstdag staat een ,heerlijke dag” met den heer Teillers, een tocht naar Toegoe, aangeteekend; dan hebben de afscheidsbezoeken plaats, waarbij men verbaasd staat over het groote aantal daarvoor in aanmerking komende menschen, bagage wordt bij den heer Moquette gedeponeerd, en op 1 Januari 1910 verlaat Rouffaer Batavia.

Onderweg is eerst Baraboedoer aan de beurt, nadat een middag aan het rondzwerven in het van ouds bekende Jogja is besteed; op Baraboedoer was, zooals men weet, in die jaren de groote restauratie door Van Erp in vollen gang, en het sprak van zelf dat Rouffaer die met eigen oogen wenschte te zien; hij had trouwens het secretariaat der Commissie van Bijstand niet neergelegd, daartoe in staat gesteld door de bereidwilligheid van den heer IJzerman om het tijdelijk waar te nemen. Met tram en karretje komt hij eerst aan Mĕndoet. „Indruk beslist teleurstellend. Kath. vestiging, Kath. school, kerkplein, hek, 2 pondokken, ellendige deur, geen ruimte bij voorgevel, benauwd! Bijna gereed, komt Van Erp de trappen op. Met hem mijn indrukken bespreken. Dan samen met vlot, benedenstrooms ruine der in begin 1905 ingestorte brug, naar $\mathrm{Tj}$. Pawon, dat heerlijk is en stemmend. Dan naar Boroboedoer, bij Van Erp aan huis. 'S middags heerlijk slapen, trots donderbui; en verfrischt met Van Erp en zijn vrouw den B. op, waar ik zie hoe kranig Van Erp zijn werk doet (silhouet, bovenste rij dagobs, boven-dagob met pijnakel, rechtzetten muren, aanvullen reliefs, bijzoeken steenen). Boven op B. wensch ik hem geluk met zijn werk. Laat in donker naar beneden."

Volgt een kort bezoek aan Prambanan, en verdere doorreis naar Soerabaja; ook daar weer veel bezoeken en gesprekken, en ten slotte op 8 Januari de inscheping naar Koepang. De reis naar de Buitenbezittingen is eindelijk begonnen, maar een derde van den beschikbaren tijd van twee jaar is reeds verloren gegaan.

Verloren? Die kwalificatie lijkt al zeer onbillijk, als men bedenkt, hoeveel Rouffaer in die zeven maanden op Java had opgestoken, hoeveel hij op gang gebracht had of op andere wijze van zijn aanwezigheid had doen profiteeren. Maar toch wel verloren uit het oogpunt van het doel der Indische reis. Van een systematischen onder- 
zoekingstocht door den Archipel zou onmogelijk meer iets kunnen komen; deze studie moest fragmentarisch blijven. Rouffaer's ongebreidelde belangstelling in alles en nog wat en het ontbreken van een vast studieplan hebben hem hier geschaad; ook natuurlijk het feit, dat hij aan niemand rekenschap had te geven van zijn doen en laten, en zich bij het volgen der neiging van het oogenblik door niets hoefde te laten weerhouden.

Op de verschillende plaatsen, die de boot aandoet, gaat Rouffaer geregeld aan land, doorgaans in gezelschap van luitenant Uhl, die eveneens onder de passagiers behoort. Overal orienteert hij zich, spreekt met de autoriteiten en met andere personen, makt als de dienstregeling dat toelaat kleine tochtjes en bereidt op de plaatsen, waar hij later terug denkt te komen, dat latere verblijf eenigermate voor. Het eerst wordt Lombok even bezocht, Mataram, Tjakraněgara, Majoera, dan ligt de boot even stil te Laboean Soembawa en te Bima, vervolgens voor Waingapoe op Soemba, daarna Ende, eindelijk Sawoe, waar Rouffaer verrukt is over een bezoek aan de zonne-offersteenen, en ten slotte wordt via Roti op 14 Januari het einddoel Koepang bereikt. Daar neemt hij zijn intrek bij de familie Spruijt; de majoor Spruijt was militair commandant der residentie Timor en juist in die kwaliteit met de registratie belast. Bij alle voorafgaande en volgende bezoeken blijft Rouffaer steeds de belangen der wetenschappelijke lichamen behartigen, en verzamelt voorwerpen voor het Bataviaasch Genootschap en boeken voor de Koloniale Bibliotheek.

Behalve aan zijn gastheer heeft Rouffaer te Koepang veel gehad aan den predikant S. A. de Vries, welke in het bezit was van een particuliere bibliotheek met allerlei geschriften over de residentie Timor. Met elk van beiden ondernam hij herhaaldelijk uitstapjes. Koepang bleef voorloopig zijn pied-à-terre; hij ging van hier met Spruijt op groote tochten naar de andere eilanden uit, doch kwam er telkens weer terug en heeft er zoodoende alles bij elkaar een kleine drie maanden vertoefd. Dien tijd besteedde hij hoofdzakelijk aan studie van de toestanden in de residentie en liet daartoe nog andere boeken uit Batavia komen. Ook gaf resident Loriaux hem gelegenheid inzage te nemen van het oudere residentie-archief.

De eerste der reizen met majoor Spruijt vangt reeds op 19 Januari aan. Via Larantoeka, waar aandacht wordt besteed aan het Franciscanessen-klooster en de Jezuietenmissie, gaat de vaart naar Lamahala op Solor; verdere tochten volgen te voet en te paard, Rouffaer 
maakt de registratie mee en schrijft zijn aanteekeningen. Na eenige dagen wordt de reis voortgezet naar Maumerĕ en Sagoe (Adonara) en zoo komt men te Larantoeka terug, waar het gebruikelijke wachten op de K. P. M. boot tot verdere studie aanleiding geeft; Rouffaer staat dan bv. om drie uur 's morgens op, leest eerst van alles, brengt een bezoek, maakt dan een wandeling, enz., alles getuigend van een vermoeiend, maar zeer frisch en opgewekt werken.

Als de boot arriveert, blijkt aan boord te zijn de heer A. C. Soveral Martins, de nieuwbenoemde gouverneur van Portugeesch-Timor, een zeer beschaafd en taalkundig man. Deze dringt er bij Rouffaer zeer op aan, te zijner tijd de voorgenomen reis door Portugeesch-Timor te maken en belooft hem daarbij alle medewerking. Langs Alor kětjil bereikt men Dilly; op 5 Februari woont Rouffaer de plechtige installatie van den gouverneur bij, met inlandsche dansen en dergelijke feestelijkheden, terwijl hij 's avonds weder met dezelfde boot teruggaat. Den volgenden dag wordt Atapoepoe bezocht, en gaat hij ,.langs melancolieken weg naar het dito fortje en het dito huis van den dito controleur". Er is gelegenheid voor een tocht van eenige uren het binnenland in, maar niet voor meer, en de bedoeling is, dat later een meer gezette studie ter plaatse zal volgen.

Op 7 Februari begint een wat langer verblijf te Koepang, thans van ruim vijf weken, met het gewone leven van de binnenplaats, de „bekende Indische vervelingspraat”, enz. Op een pandhuisverkooping ziet hij een snoer van moetisalah's, waarover hij zooveel vellen had volgeschreven, onder den hamer komen. De studie gaat geregeld voort, en tevens is het Rouffaer duidelijk geworden, dat om tot een resultaat te komen, verlenging van zijn reis noodzakelijk zal zijn. Hij richt zich dan ook tot het Aardrijkskundig Genootschap om hem tot een derde jaar in Indië in staat te stellen. Reeds begin Maart wordt den resident als gevolg van wat Rouffaer heeft opgemerkt, een lijstje van desiderata overhandigd; maar zelf slaat hij ook de hand aan het werk en begint de residentie-bibliotheek op te redderen. In het archief treft hij met andere belangrijke stukken het origineele contract-Paravicini, en gaat dan ,,verrukt naar huis”. Een tocht van wat grooter omvang is die naar Amarasi en het Zuiderstrand.

De tweede reis met Spruijt begint op 16 Maart. Dan wordt eerst Naiklioe aan de Noordwest-kust aangedaan en vervolgens Lamakera op Solor. Bij deze en bij volgende zeereizen maakt Rouffaer telkens schetsjes van de kustlijnen, zooals hij ze van boord waarneemt, en teekent ook andere dergelijke landverkenningen aan. Het 
doel van deze reis is Lomblem, en nadat een eerste poging om voeling te krijgen met den daar vertoevenden kapitein Beckering mislukt is, gaat het op 19 Maart beter; men landt dan en trekt het binnenland in naar het bivak aan de Wai Wewang. Ook hier heeft de registratie plaats; bij zulke gelegenheden krijgen wij allerlei wetenswaardigs over de inlanders en de inlandsche hoofden te hooren. Een paar maal wordt onder behoorlijke dekking nog wat meer van het binnenland gezien, langs de versterkte en gepalissadeerde kampoengs, want er is nog kort geleden verzet geboden. Zulke tochten zijn steeds bijzonder naar Rouffaer's zin; bij een van deze gelegenheden wordt ook de nog niet lang bekende vulkaan Ili Wěroeng nader verkend, doch tot een beklimming komt het niet, daar een diep ravijn voor den Westwand van den krater blijkt te liggen, en de tijd dringt. Het is ook bij dezen tocht, dat Rouffaer voor het eerst zijn uit den Haag meegenomen foto-toestel in gebruik is gaan nemen, waarmede hij al gauw resultaten wist te bereiken, die hem bevredigend toeschenen.

$\mathrm{Na}$ terugkomst in Koepang op 29 Maart, waar hij dan weer ruim drie weken stil is, worden enkele nieuwe gegevens in een stukje voor het Aardrijkskundig Genootschap beschreven; ook smaakt hij wat hij zelf een zalig gevoel van voldoening noemt, als hij verneemt, dat zijn vermoeden aangaande het bestaan van een hoogvlakte in het stroombed van de Mambèråmo op Nieuw-Guinea door de nieuwe expeditie is bevonden in overeenstemming met de werkelijkheid te zijn. Hij woont verder een zitting van den Raad van Landshoofden bij, en krijgt van den radja van Tabenoe allerlei gegevens over de oude toestanden op Timor, welke hij tracht met de Nederlandsche en Portugeesche berichten in harmonie te brengen. Merkwaardig is, hoe temidden van al dergelijke onderzoekingen zijn belangstelling tegelijk op geheel andere zaken gericht kon blijven; zoo verdiept hij zich in dezen tijd in wat er bekend is geworden van den RhaetischGermaanschen limes van keizer Hadrianus, gelijk hij op een ander moment met aandacht de controvers psalmen of gezangen blijkt te volgen. Van tijd tot tijd vernemen wij, ongetwijfeld tengevolge van de groote inspanning op de reizen, dat hij zich minder goed gevoelt, zonder zich daardoor overigens van iets anders te laten terughouden dan van eten.

Aan het volgend uitstapje, van 24 tot 30 April, heeft hij dan ook minder gehad; hij stapt „zwiemelend op de beenen” te Ende af, komt opnieuw te Larantoeka, waar hij juist een Hoofdenraad treft, en doet op West-Flores de kustplaatsen Reo en Laboean Badjo aan, 
doch keert nog altijd onlekker, en sukkelend met hart en maag, naar Koepang terug. Toch gaat hij twee dagen later vol moed opnieuw scheep, thans naar Namodale op Roti, waar hij te paard een grooten tocht van drie dagen door het eiland maakt, eerst naar Sĕdah, vervolgens naar Keasin, en eindelijk weder naar Namodale, waar hij zich vermoeid inscheept. Dit reisje is op 7 Mei afgeloopen. Zoowel bij de beschrijving in dagboekvorm van zijn wedervaren op al zulke tochten, als in de afzonderlijke aanteekeningen dienaangaande, worden tal van merkwaardige gegevens gevonden, die het jammer is zonder meer voorbij te gaan. Daar zij intusschen meer van belang zijn uit ethnologisch gezichtspunt dan voor de kennis van Rouffaer's levensloop, moeten wij de details hier wel terzijde laten, echter eens en vooral constateerende, dat hij voortdurend blijk blijft geven van zijn scherpen blik en groote opmerkingsgave, evenals van het vermogen om in enkele woorden een indruk of een overzicht neer te schrijven, dat niet alleen bij hemzelf het geval later in de herinnering kon terugroepen, maar ook aan den lezer, voor wien het toch niet bestemd was, direct een duidelijk beeld van het waargenomene geeft.

De dan weder volgende dagen op Koepang worden ten deele aan een stuk voor het Aardrijkskundig Genootschap besteed; in dezen tijd treffen Rouffaer tevens een paar teleurstellingen. De eerste is het bericht, dat de expeditie-Franssen Herderschée wegens ziekte had moeten omkeeren. In een beschouwing over de resultaten dezer expeditie ${ }^{1}$ ) wordt geopperd, dat $\mathrm{zij}$ bij wat langer tijd van voorbereiding nog meer zou hebben kunnen bereiken: wij zagen hierboven wat de oorzaak der bespoedigde uitzending was, de ook door Rouffaer gedeelde vrees, dat anders anderen vóór zouden zijn. Volkomen verdiend was het, dat aan een der zijrivieren van de Mambèråmo de naam van Rouffaer-rivier werd gegeven.

De tweede teleurstellende mededeeling was de overplaatsing van majoor Spruijt naar Batavia. De op $12 \mathrm{Mei}$ ondernomen tocht naar Soemba zou dus de laatste in gezelschap van zijn gastheer zijn.

Het eerste stukje van de reis, tot Ende, wordt meegemaakt door den geoloog dr. Pannekoek van Rheden, en met hem spreekt Rouffaer af, hem in Juni weder te zullen ontmoeten in de Soa-streek. Als Waingapoe bereikt is, begint een zevendaagsche tocht door Soemba ; eerst naar Mělolo, dan naar het bivak Parokoet, vervolgens naar Kananggar, waar de eerste dolmen-achtige graven worden

1) Tijdschr. Aardr. Gen. 28 (1911) p. 460. 
bezichtigd - op de volgende dagen zullen er nog meer volgen en dan naar Waingapoe terug. Het laatste stuk van den tocht heeft plaats in gezelschap van den civiel-gezaghebber luitenant Rijnders, met wien een afspraak voor een rustiger bezoek tegen October wordt gemaakt. Ook van dezen tocht keert Rouffaer innig voldaan, maar doodmoe, terug, en die moeheid is nog niet geweken, als hij opnieuw, en nu voor het laatst, te Koepang vertoeft. De familie Spruijt houdt vendutie; Rouffaer heeft zijn pied-à-terre verloren en er is voor hem geen aanleiding meer om later weer naar Koepang terug te gaan. Hij heeft intusschen bericht ontvangen, dat het Aardrijkskundig Genootschap zijn verzoek om een jaar verlenging van de reis heeft toegestaan, en zal dus zijn plaatselijke onderzoekingen zonder te groote overhaasting kunnen voortzetten. Overeenkomstig de afspraak met dr. Van Rheden is thans allereerst Flores aan de beurt.

De boot, die op 6 Juni vertrekt - al deze tochten worden natuurlijk per gouvernementsstoomer gedaan - zet eerst koers naar Lomblem, waar een deel van de registratietroepen na volbracht werk weer aan boord wordt genomen ${ }^{1}$ ). Een paar weken is Rouffaer daarna op Ende stil, en bewoont er het huis van den met verlof vertrokken civiel-gezaghebber, tezamen met dr. Sörensen. Zijn bezigheden zijn als gewoonlijk; hij bestijgt den Goenoeng Api, maakt wandelingen, woont de zitting van den Raad van Landschapshoofden bij, studeert in de stukken, die de controleur ter zijner beschikking stelt. Daarnevens heeft hij ook belangstelling voor het werk van zijn huisgenoot, gaat naar de ziekenzaal en laat zich ook daar een en ander uitleggen.

Den 22sten vertrekt hij naar Aimerě, en den volgenden dag rijdt hij naar boven, waar Badjawa hem eenige weken lang zal herbergen; hij vindt er dr. Van Rheden en den civiel-gezaghebber van Ngada, luitenant Spandaw. Als voorbeeld van de wijze, waarop hij zijn dagen besteedt en daarvan aanteekening houdt, laten wij één zoo'n dagmemorandum volgen, volstrekt geen met buitengewone gebeurtenissen, doch een specimen van wat gewoonlijk opgeschreven wordt.

„Vrij. 24 Juni. Verkwikt opgestaan, ga ik, na wat eten, alleen dolen voor eerste indrukken en blijk den weg naar kampoeng Naroe te zijn opgegaan. Op weg daarheen zie ik voor het eerst de karakteristieke ploegstokken gebruiken, 3 à $4 \mathrm{M}$. hooge bamboe-stokken met één zijtakje als tred voor den voet behouden, drie man naast

1) Op verzoek van Rouffaer heeft kapitein Beckering van zijn bevindingen op Adonara en Lomblem mededeeling gedaan in Tijdschr. Aardr. Gen. 28 (1911) p. 167-202. 
elkaar, eerst indiepende, dan òmhalend al meer en meer, en dan eindelijk met een gezamenlijken terugslag een breede langwerpige klont naar voren òmleggende. Doorgaande, kom ik in kampoeng Naroe en sta versteld te kijken over de merkwaardige regelmaat van deze naar het $\mathrm{O}$. gerichte kampoeng, den terrassenbouw, het vrouwenhuis in 't midden, de twee daarop volgende aan negerkampoeng's herinnerende pajoeng-huisjes om elk één offerpaal, en dan nog hooger de monolithische graven met hun uitstekende grafteekens. Dan wandel ik denzelfden weg terug, diep getroffen door de overeenkomst in eigenaardige beschaving tusschen Soemba en (ten minste) den uitgebreiden Ngada-stam in Midden-Flores. 'S namiddags zijn er diversen van praten enz., en wordt 's avonds de koude voelbaarder, zoodat ik met genot, zelfs met koude voeten, onder twee wollen dekens in slaap ga."

Verschillende tochten worden ondernomen, hetzij met Spandaw, zoo bijvoorbeeld naar Boa Wai, hetzij met Van Rheden, met wien een bezoek wordt gebracht aan den vulkaan Inijĕ Lika, het vier jaren tevoren plotseling ontstaan eruptiepunt, hetzij alleen, hetzij met zijn drieën. Op een gezamenlijk uitstapje van eenige dagen naar Mana Tena is Rouffaer doodmoe en stijf, en moet wat rust nemen. De beide anderen hebben trouwens ook hun eigen werk; dr. Van Rheden doet zijn geologische verkenningen, en luitenant Spandaw bezoekt de kampoengs, waar soms nog wel wordt gevochten. Ook in andere opzichten heeft Rouffaer veel aan den heer Van Rheden gehad, hij houdt met dezen diepzinnige gesprekken, die hem geestelijk verkwikken, en deelt hem iets mede van zijn levensdoel. Een gevolg is de lectuur van Schopenhauer, die echter niet meevalt. Op 7 Juli viert Rouffaer zijn vijftigsten verjaardag met het schrijven van een stukje over den Inijě Lika.

Op $19 \mathrm{Juli}$, na een tocht met Van Rheden door de Soa-dorpen, teekent Rouffaer aan: ,een verrukkelijke rijdag op mijn lief zwart paard." Maar er is al weer een ander plan, dat het verblijf op Flores zal onderbreken: den 23sten komt plotseling het idee op om heen en weer met de boot naar Makassar te gaan, ten einde Bima aan te doen en Makassar te zien en daar wat inkoopen te doen. Zoo gezegd, zoo gedaan; den 25 sten is hij al weer te Aimerĕ en den volgenden dag aan boord. Langs Waingapoe, Badjo en Bima, waar voorbereiding wordt gemaakt voor den terugkeer, komt hij op 29 Juli te Makassar aan.

De tijd in die stad, welke een gunstigen indruk van flinke Indische 
havenplaats maakt, is kort, slechts twee dagen, maar die worden dan ook, dank zij de medewerking van allerlei autoriteiten, uitgebuit. Een autotocht naar Takalar, een bezoek aan de roemah Boni, de oude koepelachtige graven op het land Tompo Balang, en nog een autotocht naar Maros zijn het, die deze dagen voornamelijk vullen, met de inkoopen en vele gesprekken, waarbij Rouffaer nog aanleiding heeft stom verbaasd te staan, als hem zoowaar een „Catalogus der gewestelijke bibliotheek" in handen wordt gegeven. $\mathrm{Na}$ al zijn ijveren voor het tot stand komen van zulke bibliotheken elders was dat een aangename ondervinding, en hij belooft dan ook zijn hulp om deze boekerij verder uit te breiden.

Op de boot terug is de geoloog dr. Sandberg een interessante reisgenoot, doch reeds den volgenden dag moet Rouffaer te Bima het schip verlaten. De noodige toebereidselen blijken door den gezaghebber Banse te zijn getroffen, en zoo kan het elfdaagsch verblijf op Bima nog heel wat resultaten hebben, dank zij ook de welwillendheid van de sultansfamilie en van den intelligenten Boemi (secretaris) Djafar. De koebah's (koepelgraven) worden bekeken; een tweetal oude fortjes wordt herkend als nog te stammen uit den Compagniestijd en in de grot van Batoe Pahat kan met zekerheid de aanwezigheid van Çiwaisme in de veertiende en vijftiende eeuw geconstateerd worden. De poesaka's van het sultansgeslacht en de gegevens uit een paar door den kroonprins te voorschijn gehaalde historieboeken worden bestudeerd. Ook de tocht naar wat eigenlijk het hoofddoel van de komst op Bima was, de Wadoe toenti boven Palama, heeft groot succes. Hier blijkt, op 6 en 7 Augustus, de aanwezigheid van een duidelijke inscriptie in Oud-Javaansch schrift, met een afbeelding van wat Rouffaer voor een Çiwa houdt; hij maakt een afprent en foto's en is verrukt over deze prachtige vondst. Onderweg wordt een grafurn ontgraven, en deze laatste ontdekking kan een paar dagen later worden gecompleteerd, als op een tocht naar Tentě en den Goenoeng Parewa soortgelijke oudheden worden aangetroffen, te merkwaardiger door den grooten afstand van Palama.

Den 12den Augustus moet het verblijf weer beëindigd worden; thans is aan boord de nieuwe voor Flores bestemde civiel-gezaghebber Van Suchtelen, met wien Rouffaer later ook weder in aanraking zou komen. Na nog een uitstapje te Waingapoe is hij op 14 te Aimerĕ en op 16 Augustus te Badjawa terug. De tweede helft van het bezoek aan Flores duurt dan nog ongeveer vijf weken.

Tijdens dit tweede verblijf te Badjawa wordt de studie van den 
Islam afgewisseld met die van Tolstoi. Een met luitenant Spandaw ondernomen tocht naar Boa Wai kan niet verder worden voortgezet, omdat zijn geleider plotseling naar Koepang wordt geroepen; Rouffaer maakt dan wel alleen uitstapjes, maar komt na een dag of zes vermoeid en wat pijnlijk weer in Badjawa. Daar gaat het op denzelfden voet voort, tot op 8 September het plotselinge besluit valt om nu eerst naar Portugeesch-Timor of de Zuidwester-eilanden te gaan en tevens nog iets van Manggarai te zien.

Van Aimerĕ gaat het naar Mborong en dan wordt te Sita de eerste Manggaraische kampoeng aanschouwd, zijnde één groot huis. Vervolgens wordt Kempo aangedaan, maar inmiddels begint weer wat gesukkel met het hart. Toch gaat de tocht verder, langs het eerste in den Timor-archipel aangetroffen meertje (Wai Sano). „Dan volgt de heerlijke wandeling door het oerbosch, prachtig uitgekapt een $10 \mathrm{M}$. breed door den instructeur Zijlstra te Roetěng, waarbij zacht glooiend oploopend na $1 / 4$ uur boven het meertje de waterscheiding wordt bereikt, en dan zacht afglooiende het oerbosch nog ruim $1 / 2$ uur aanhoudt; een goddelijke diep-poëtische wandeling door het frissche en mooi door de opkomende [zon] verlichte zwaar hoogstammige bosch, vol vogelgezang nu nog (van $1 / 2 \quad 8-1 / 2 \quad 9$ trok ik er door) en met makkelijk looppad. Een onvergetelijk stuk Indische herinnering!" Helaas is het niet altijd zoo, want als den volgenden dag van Roetěng uit een tocht naar het gevechtsterrein van Koewoe wordt ondernomen, maken de moeilijkheden van het terrein en de daardoor ontstane vermoeidheid dit den ,tot nog toe ellendigsten tocht in Indië gedaan". Het plan om langs een omweg naar Mborong terug te gaan, wordt dan ook opgegeven, en ook van een anderen bergtocht keert Rouffaer onverrichterzake terug, rillerig en onlekker. Via Mborong en Aimerě worlt de Paketboot Le Maire opgevangen, die hem Oostwaarts zal brengen. Definitief wordt nu bepaald, dat het doel vooreerst Portugeesch-Timor zal zijn, want aan boord verneemt hij, dat de hem bekende gouverneur, van wiens hulp hij gaarne gebruik wil maken, om de gezondheid van zijn vrouw reeds in November denkt te repatrieeren.

Langs de gewone reeds vroeger gevolgde route - te Koepang worden oude vrienden opgezocht - bereikt Rouffaer op 25 September Dilly; hij gaat aan land en maakt eenige afspraken met dr. Osorio de Castro, om alles in orde te hebben als hij een week later met dezelfde boot in Dilly terug zal zijn. Op de eilanden, die dan verder aangedaan worden, is slechts weinig tijd om bijzonderheden 
te zien; dat geldt voor Wetar en Kisar evenals voor Leti; overal blijft het een vluchtig bezoek. Te Sĕrwaroe (Leti) treft hem de mededeeling van den posthouder over de aanwezigheid van een keteltrom te Loehoelele en van fragmenten van nog een andere te Tapoe Lewang; hij spreekt af op de terugreis in elk geval dien eerste te gaan zien. Op Damar wordt van de gelegenheid gebruik gemaakt om een vroeger opgevangen bericht van de aanwezigheid eener rotsinscriptie aan den Noordoost-punt der Koelwati-baai te verifieeren; in een kòrakòra gaat Rouffaer er ondanks de ongunstige zee naar toe, doch het blijken slechts horizontale strepen met ritsen, en stellig geen inscriptie te zijn. Teleurgesteld over den vergeefschen tocht, maar blij de legende voorgoed uit de wereld te kunnen helpen, komt hij weer terug, en verdiept zich dan verder in de op Damar kort geleden begonnen zwavelwinning.

Zoo bereikt de boot op 29 September zijn eindpunt Port Darwin, welke plaats ondanks het flinke type der daar werkende Engelschen toch een troosteloozen indruk maakt van lang niet te zijn geworden wat het had willen zijn. Denzelfden dag gaat de Le Maire alweer terug, en op 1 October wacht Rouffaer op Leti opnieuw teleurstelling. De boot, tegen zes uur voor Serrwaroe aangekomen, zal reeds om acht uur vertrekken en er is dan geen tijd voor Loehoelele. Slechts kan een rit worden ondernomen naar de keteltrom van Tapoe Lewang, waarvan eenige fragmenten, naar Sĕrwaroe gebracht, het bestaan en de echtheid buiten twijfel stellen. Helaas, de afstand valt niet mee, en op een gegeven moment moet worden omgedraaid; en het ergste is dat als men weer goed en wel terug is, het vertrek van de boot blijkt te zijn uitgesteld.

Ten slotte is men dan op 2 October weer voor Dilly, en dan begint Rouffaer's verblijf op Portugeesch-Timor, dat op een paar dagen na de geheele maand vult. Ter hoofdplaats logeert hij bij Joaquim de Sousa e Brito, Director da Alfandega; de Gouverneur wordt bezocht, evenals dr. Osorio de Castro, waar een geheel reisplan, opgesteld door den Director das Obras Publicas, blijkt gereed te liggen. $\mathrm{Na}$ nog een dag van preparatieven, gaat het op 4 October het binnenland in.

Van deze reis door het Westelijk deel van Portugeesch-Timor in haar wel snel maar toch rustig en gemakkelijk verloop - Rouffaer werd geheel als gouvernements-reiziger behandeld en genoot de voortdurende zorg der plaatselijke autoriteiten, terwijl hij bovendien waar hij wilde telefonisch met den gouverneur in aanraking kon 
komen - geeft het dagboek de route. De weg in alle eigenaardigheden wordt telkens uitvoerig beschreven, met wat er van beplanting of bebouwing te zien is, de natuur en de doorgetrokken plaatsen worden aangegeven, metingen en geologische waarnemingen vinden er een plaats; waar het kan documenteert Rouffaer zich over administratie en dergelijke, maar over het algemeen draagt dit stuk dagboek een veel minder persoonlijk karakter dan wat voorafgaat. De Portugeezen doen zich van hun beste zijden kennen; meer dan elders vinden wij thans bij de kennismaking met nieuwe personen het adjectief ,sympathiek” gebruikt. Telkens zijn er natuurlijk ook weer ethnologische opmerkingen, en vergelijkingen met het in de rest van den Timor-archipel waargenomene.

Eerst gaat de route langs het strand Westwaarts; dan van Liquiça recht naar het Zuiden en Zuid-Westen, totdat bij Sitaba de grens met Nederlandsch-Timor is bereikt. Een heel stuk wordt die grens langs den evenwijdig loopenden weg gevolgd; te Bobonaro wordt wat rust gehouden en daar verneemt Rouffaer de Portugeesche lezing van den beruchten overval van Lakmaras, die den 3den October van Portugeesch-Timor uit op Nederlandsch gebied heeft plaats gehad. Rouffaer neemt het verhaal aan voor wat het is, maar blijkt later zijn eigen oordeel te hebben en te begrijpen, welke Portugeesche officier de aanstoker is geweest. Van Bobonaro trekt hij naar de Zuidkust, tot zijn verbazing bemerkend, hoe de Portugeezen door het nog Nederlandsche Maucatar hun colonne-wegen hadden gelegd, zonder dat daar te Atapoepoe of Koepang iets van bekend was.

Eveneens aan de Zuidkust, maar Oostelijker, heeft hij de onaangename ondervinding, dat zijn goed niet is aangekomen en hij den nacht op een mat moet doorbrengen; later stelt het verblijf te Same in de prettigste en meest beschaafde omgeving, die hij op deze reis aantrof, hem schadeloos. Nog weer Oostelijker ligt Fato Barliu, waar hij op 23 October iets hoort van de revolutie te Lissabon, die toch al 18 dagen geleden had plaats gevonden; heel openhartig tegenover den vreemdeling was men toch niet! Dan gaat de reis weer naar het Noorden, en bij Manatuto is men weer aan zee, waarop dan, nu in Westelijke richting, op 27 October Dilly wordt bereikt. De heele route is dus, zooals men ziet, een groote rechthoek.

$\mathrm{Na}$ de gebruikelijke plichtplegingen en dankbetuigingen, benevens een onderhoud met den gouverneur over Lakmaras, kan Rouffaer op 30 October nog juist de plechtige uitroeping van de republiek bijwonen, voor hij weer scheep gaat. Dienzelfden middag is hij stil 
te Atapoepoe en vertelt er den controleur van zijn bevindingen, daarbij niet verhelend, welk een gunstigen indruk PortugeeschTimor in allerlei opzichten op hem gemaakt heeft, zoodat vergelijking met het Nederlandsch gedeelte allerminst in het voordeel van dit laatste uitvalt. Als de boot den volgenden morgen te Koepang is, weet de resident via de telefoon al van dat oordeel af, en blijkt hij er zeer ontsticht over. Het onderhoud is dus niet heel aangenaam, maar Rouffaer moet spoedig weer vertrekken. Zijn voornemen is, een uitvoerige schets van de toestanden in Portugeesch-Timor, deels onder vergelijking met die in het Nederlandsch gebied, te publiceeren bij het Aardrijkskundig Genootschap.

Vooreerst echter moet nog een ander deel van het programma afgedaan worden, de reis over Soemba, waartoe afspraken waren gemaakt met den civiel-gezaghebber luitenant Rijnders en met ds. Wielenga. Inderdaad heeft deze reis plaats gehad, doch de dagboek-aanteekeningen over deze periode ontbreken, en dus kunnen wij er geen bijzonderheden van mededeelen. Het plan was om, na ankomst op 2 November te Waingapoe, met beide heeren een reisje van een maand naar Napoe - voor de doodsplechtigheden - en West-Soemba te doen tot Anakalang, en zoo mogelijk over de Tarimbang-baai en Taboendoeng terug. Of dit precies zoo uitgevoerd is, blijkt niet; waarschijnlijk niet in alle bijzonderheden, want uit een incidenteele opmerking zien wij, dat Rouffaer is begonnen met in de buurt van Mĕmboro megalithische graven op te nemen. In elk geval heeft de reis wel de voorgenomen maand geduurd; ook spreekt hij later zijn waardeering uit over hetgeen op dit eiland door Rijnders en zijn medehelpers is verricht.

Van 2 tot 6 December reist Rouffaer van Waingapoe weder naar Soerabaja; toevallig is ook nu de afgetreden gouverneur Soveral Martins aan boord. Ook over het verblijf op Java is het conceptdagboek verdwenen; een definitieven vorm hebben deze aanteekeningen nooit gekregen. Wij weten dus slechts een paar dingen, dat Rouffaer te Soerabaja met prof. Molengraaff samen was, dat hij halfweg de maand December te Magělang en op Baraboedoer was, en dat hij aan het eind van diezelfde maand te Buitenzorg en te Batavia vertoefde. Het laatste gedeelte van den beschikbaren tijd moet hoofdzakelijk besteed zijn aan de toebereidselen voor het bezoek aan de Filippijnen, dat Rouffaer thans allereerst wilde volvoeren.

Op 28 December woonde hij nog een vergadering van het Bataviaasch Genootschap bij en bood er een zeldzame gouden mĕmoeli 
van Soemba aan. Den 30sten had hij een onderhoud met den heer L. van Vuuren, destijds chef van het Encyclopaedisch Bureau, en deed hem verslag van zijn bevindingen op Timor; den inhoud van dit gesprek legde de heer Van Vuuren vast in een Nota voor den Adviseur voor de Buitenbezittingen Frijling, en deze nota, vergezeld van een contra-nota van den controleur Seyne Kok van Atapoepoe, werd vijf maanden later in handen van Rouffaer gesteld, die er, zooals wij zullen zien, aanleiding in vond zijn meening nog wat duiclelijker uiteen te zetten in zijn befaamde Timor-Nota.

Den dag na bovenbedoeld onderhoud had hij Batavia en Nederlandsch-Indië reeds verlaten, om via Singapore en Hongkong, met Macao, naar Manila te reizen. Bij het vertrek uit Hongkong, op 21 Januari 1911, beginnen de dagboek-aanteekeningen weder. Het zijn eerst een paar dagen van zeeziekte en dan een groote menigte formaliteiten, voor Rouffaer op 24 Januari aan wal stapt te Manila. De hedoeling van het bezoek aan de Filippijnen is slechts in zeer beperkte mate verwezenlijkt, want den geheelen tijd is Rouffaer te Manila zelf gebleven, daargelaten kleine uitstapjes, en toen hij op $16 \mathrm{Mei}$ weder scheep ging, had hij gedurende die bijna vier maanden slechts één nacht buiten zijn hotel te Manila doorgebracht. Ten deele is dat een gevolg van zijn gezondheidstoestand, doch deze is eerst tegen het slot een factor van beteekenis bij zijn plannen geworden; in hoofdzaak echter zien wij ook hier weder de gevolgen van het ontbreken van een vast plan van onderzoek en de geneigdheid om zich geheel door wat op het oogenblik sterk aantrekt in beslag te laten nemen. De tijd te Manila is vooral een tijd van zware bibliotheekstudie, waarbij hetgeen verder wordt opgemerkt eenigermate op den achtergrond geraakt.

Een eerste orienteering op den eigen dag van aankomst brengt Rouffaer in de typisch Spaansche binnenstad, en doet hem daarna constateeren, hoe veel minder zorg de Amerikanen aan hun boulevard's besteden dan bijvoorbeeld de Engelschen te Singapore. Eerst later zal die indruk wat worden gecompenseerd door de groote moderne gebouwen en de kranige werken op militair gebied, maar toch zal ook later de indruk blijven en zich bevestigen, dat hij nooit in het troostelooze Manila zou willen wonen. Die troosteloosheid schrijft hij voor een goed deel toe aan het gebrek aan mooie boomen.

Ook reeds den eersten dag probeert hij een bezoek te brengen aan de Cámara de Diputados, maar dat lukt eerst den volgenden dag. Ziehier de beschrijving van de leden van het Filippijnsche parlement, 
als hij de ongeveer 80 afgevaardigden, bijna allen in 't wit gekleed, op hun banken ziet zitten. ,Allen jonge sluikharige mannen van \pm 23-30 jaar, en maar zeer enkele 40-gers. Allen met smalle (dolichocephale) schedels, behalve misschien 15 à $20 \%$ brachycephalen (deels wel Bisayos?), van over 't geheel aangenaam-intelligent en nietbrutaal uiterlijk, allen converseerend en publiek sprekend in het Spaansch, gelijk ook hun couranten alle in het Spaansch zijn. Het geheel maakt een aangenamen, een beetje jongens-achtigen indruk; men zou zeggen een vergadering van beschaafde studenten. Ook de Voorzitter (Sergio Osmeña, Cebuaan) is nog een zeer jong man van \pm 33 jaar. Na onbelangrijke dingen wordt de zitting om 7 uur gesloten en ga ik naar huis. Het schilderstuk op den achtergrond der vergaderzaal (de Maagd van Amerika hulp komende bieden aan de Filippijners) is werkelijk geslaagd, goed van kleur, ingehouden van uitdrukkingen, niet-brallend, fatsoenlijk, en vrij mooi zelfs."

Het landschap van Manila wekt, evenals de dracht der bevolking, veel Spaansche herinneringen; buiten de stad doet het hem aan Aimerĕ denken, terwijl de inlandsche huizen den indruk maken van een Soendaneesche kampoeng. Wat hij van de society merkt, vervult hem met weerzin, en ook andere dingen vallen hem tegen: bij een eerste bezoek aan kerk en klooster der Augustijnen constateert hij er slechts een Katholicisme van de 2de, ja 3de, hand te vinden. Misschien is zijn gevoel van moeheid, spoedig gevolgd door een, overigens geheel verwaarloosde, influenza aan deze indrukken niet vreemd. Wat de Augustijnen betreft zou hij trouwens spoedig iets anders, de rijke bibliotheek, leeren waardeeren.

Veel leest hij de eerste weken door over de Filippijnen, en zooals van zelf spreekt begint hij ook dadelijk aanraking te zoeken met allerlei autoriteiten, wederom op het meest verschillend gebied. Als wij uit de vele namen er een paar noemen, naast den waarnemenden consul Bremer, die hem met allerlei hielp, dan zijn dat bijvoorbeeld dr. T. H. Pardo de Tavera, de Filippijnsche specialiteit, die echter buiten zijn speciale terrein weinig weet, en J. A. Robertson, bibliothecaris der Philippine Library, waar Rouffaer menig uur heeft gesleten. Bovenal echter is het de heer F. Th. Rogers, hem uit den Haag en Londen reeds eenigszins bekend, aan wien hij veel heeft gehad. Rogers kon en wilde hem in aanraking brengen met de notabiliteiten der Filippijnsche bevolking, met wie hij zelf allèrlei nauwe relaties had; in het begin wantrouwde Rouffaer dat eenigszins, bevreesd als hij was ergens voor gebruikt te worden, maar in den Dl. 84. 
loop van een geregelden, bijna dagelijkschen omgang verdween dat wantrouwen volkomen en maakte plaats voor de volmondige erkenning van Rogers' edelen aard en ongerepte bedoelingen. Binnen eenige weken was hij met Rogers op intiemen voet geraakt.

In zijn gezelschap bracht hij ook den 19den Februari door, een dag dien hij een der beide hoogtepunten van zijn verblijf te Manila achtte. Des morgens maken zij, met een redacteur der Manila Free Press, een auto-tocht naar Montalban, eerst door de sawah's waar de merkwaardige padi-offers opvallen, en dan door het suikerriet; boven het dorp gekomen genieten zij temidden der kalkrotsen van de natuur. Des middags gaan beiden naar een kerkelijke plechtigheid in de Iglesia Filipina Independiente, waar zij worden ontvangen door allerlei op den voorgrond tredende Filippijners, en daar is ,zoowaar óók Emilio Aguinaldo, nu bijna 42 jaar oud, die met zijn zwijgend, stil, bescheiden en haast wat schuw optreden een uitstekenden indruk op mij maakt. Hij ziet er nog jeugdig en flink uit, en heeft aan zijn onderlip een kleine zwelling van vleesch die óók op het portret bij Barrows (p. 284) te herkennen is.” De kathedraal is maar zóó zóó en de dienst, familiaar-Katholiek en in het Spaansch gehouden, is dat ook. „Ik voor mij blijf echter vóór alles onder den indruk van Aguinaldo met zijn stil gezicht en teruggetrokkenheid."

$\mathrm{Na}$ afloop van deze plechtigheid weer iets geheel anders: aan het station zal de voorzitter der Kamer, Osmeña, die van Batangas terugkomt, feestelijk worden ontvangen, en bij die gelegenheid wordt ook Rouffaer door Rogers aan hem voorgesteld. Als Osmeña in een versierde electrische tram is weggereden, begeven beiden zich eveneens naar diens huis, en krijgen daar temidden van vele andere gasten gelegenheid tot een kort gesprek, hetwelk Rouffaer's gunstigen indruk van dezen Filippijnschen edelman bevestigt en tot de afspraak van een later rustiger bezoek leidt. Een maaltijd met een drietal Amerikanen onder zware politieke gesprekken besluit een wel zeer vermoeienden, maar ook zeer vruchtbaren dag.

Inmiddels is Rouffaer met bezoeken aan en studies in verschillende kloosterbibliotheken aangevangen, de reeds genoemde Augustijnen, maar ook de Franciscanen, Dominicanen en Jezuieten. Behalve eigen onderzoek is daarbij tevens de bedoeling om aankoopen te doen van de boekuitgaven dezer orden, die elders niet, en hier dikwijls niet zonder moeite, te krijgen waren. Rouffaer's ondervindingen met de paters, de wijze, waarop hij nu eens achterdochtig dan weer gul en hartelijk ontvangen wordt, en men hem soms probeert af te 
zetten, maar ook wel de verlangde boeken voor een spotprijsje of zelfs geheel voor niets afstaat, vullen heele stukken, en niet de minst amusante, van het memorandum.

Bij zijn studie komt hij nu een zaak op het spoor, die het grootste deel van zijn aandacht in beslag gaat nemen, tot schade eenigszins van wat toch het voornaamste doel van zijn verblijf moest zijn. Er bestond een communis opinio, dat alle oude specimina van Filippijnsche letterschriften verloren waren gegaan, en dat werd Rouffaer dan ook herhaaldelijk als feit medegedeeld. Maar zie, in een boek van De Mas uit 1843 vond hij, dat deze auteur een aantal oude documenten van dien aard, waaronder een uit 1652, in handen had gehad, o.a. uit het archief der Augustijnen te Manila. „Ik sta verstomd! Heeft dan niemand nog beproefd om o.a. in het Augustijnerarchief dit geschrift van 1652 (èn andere dergelijke!) terug te vinden. Moet ik soms de eerste zijn..." enz. Inderdaad, hij voelde zich geroepen om, verrast en verontwaardigd als hij was, de kwestie verder na te speuren.

Hoewel het nu tenslotte niet hijzelf is geweest, die de documenten heeft opgespoord, maar pater Rubin, aan wien hij zijn ontdekking had medegedeeld, en die een vijftal Tagalog-stukken van 1643 tot 1661 vond, bleef dit onderzoek hem zoo bezighouden, dat hij van die stukken copieën ging maken en een verhandeling op touw zette over het oude Filippijnsche letterschrift, een hachelijke onderneming voor een niet-taalkundige - hij was dan ook voornemens het artikel eerst in handen van prof. Kern te stellen - die hem heel veel tijd heeft gekost, en die het toch tot geen verder resultaat dan elf bladzijden, met veel noten, maar nooit voltooid, heeft gebracht.

Een soort van Pasar Malěm, hier te Manila vastgeknoopt aan het carneval, brengt Rouffaer in aanraking met allerlei volksnijverheid; hij voelt zich echter weer minder goed, en wordt ook sterk getroffen door het uit Nederland ontvangen bericht van het overlijden van zijn zwager De Jongh; met zijn zuster, mevrouw De Jongh, is hij gedurende de geheele reis in geregelde en voortdurende briefwisseling gebleven.

Het vooruitzicht dat, zooals het werk nu vorderde, de Indische reis in drie jaar niet voltooid zou zijn, deed hem besluiten bij het Aardrijkskundig Genootschap voor een vierde jaar subsidie an te vragen; ook Utrecht zou nog wat langer geduld moeten hebben. Naast taalkundige kwesties, die hem het gezelschap van dr. Otto Scheerer deden zoeken, waren het thans tevens museum-bezoeken, 
welke hem eenige dagen bezighielden; de groote verrassingen lagen hier op het gebied der kleedjes, en bestonden uit het flauw voorkomen van ketting-ikat bij Ilokanen en Ifugao's, en het primitief batikken bij de Manobo's om de Sarangani-baai. Maar de museum-aanteekeningen beslaan toch niet meer dan vier blaadjes en de groote attractie blijft liggen in de bibliotheken.

Enkele uitstapjes brengen wat afwisseling, met Rogers naar Antipola, het Katholiek Buitenzorg van oud-Manila, en op eigen gelegenheid naar Cavite, hetwelk als een soort Filippijnsch Enkhuizen wordt gekenschetst; een daarbij aansluitende poging om te Cavite Viejo een bezoek aan Aguinaldo te brengen mislukt door diens afwezigheid. De mooiste en rijkste dag, met den beschreven 19den Februari, is echter 14 Maart, en die dag wordt uitsluitend en bijna geheel ingenomen door een bezoek bij Scheerer, van 's ochtends elf tot 's avonds tien uur, ,een heerlijke dag, vol nieuws voor hem en mij". Er gebeurt niets anders dan praten, maar deze uitwisseling van inzicht, bijna uitsluitend beperkt blijvend tot taal en taalverwantschap, is klaarblijkelijk voor Rouffaer een groot genot geweest.

De aanteekeningen over minder bevredigende gezondheid worden talrijker, maar de ingespannen studie in de kloosterbibliotheken gaat onverdroten verder. Een heele kist met boeken voor de Koloniale Bibliotheek (het crediet is reeds lang en ver overschreden) is van die bezoeken een der resultaten. Op 7 en 8 April heeft de eenige onderbreking van het verblijf te Manila plaats, eigenlijk geheel toevallig. Een gesprek met den geoloog Smith, chief of the Division of Mines in het Bureau of Science, en eenige opmerkingen van Rouffaer over vulkanische erupties, brengen eerstgenoemde tot de vraag, of Rouffaer ook lust zou hebben dienzelfden middag nog mee te gaan op een tocht naar den vulkaan Taäl, waarvan kort na diens aankomst te Manila juist een uitbarsting had plaats gevonden. Het besluit is spoedig genomen en om zes uur zit men in den trein; ook een tweede geoloog, Rowley, is van de partij.

Het is reeds geheel donker, als men te Tananan uitstapt, en na het eten rijden de heeren om halftien met zijn vieren - de eigenaar van het hotel te Tananan is er nu ook bij - in den maneschijn naar Bañadero, in twee karretjes langs een afschuwelijken en stoffigen binnenweg; in een tent wordt overnacht. 's Morgens vroeg gaat men per motorboot naar het vulkaaneiland, en beginnen de geologen een onderzoek, dat geen bijster wetenschappelijken indruk maakt. Om tien uur is het afgeloopen, en dan begint in omgekeerde volg- 
orde de terugtocht; het aardigste van den rit per karretje is het tegenkomen van een groote doop-partij te paard. Wat Rouffaer op dezen rit en uit de raampjes van den trein ziet, is zijn eenige ondervinding van het binnenland van Luzon. 's Avonds is hij doodmoe weder in Manila terug.

Misschien is deze tocht te vermoeiend geweest; in elk geval laat in den loop van April de gezondheid steeds meer te wenschen over. Een week later is een uitstapje naar Taguig, met terugreis per boot, de laatste excursie buiten de stad; den dag daarna valt aan Rouffaer nog eens een merkwaardige ontdekking ten deel, doordat hij in het museum der paters Jezuieten onder een drietal metalen beeldjes een vierarmigen Çiwa en een verinlandschten Ganeça ontdekt, hoogst belangrijk in verband met de bijna volkomen afwezigheid van alle sporen van Hindoe-invloed op de Filippijnen. Maar een paar dagen later valt Rouffaer flauw, en hoewel hij de bibliotheekstudie nog niet onderbreekt, en van den ethnoloog Beyer nog allerlei bijzonderheden over de Irugao's opteekent, acht hij het toch wenschelijk zich door dr. Saleeby - dien hij als stoeren maar wat wilden werker op taalgebied reeds ontmoet had - te laten onderzoeken. De diagnose luidt hartzwakte tengevolge van neuritis, met allerlei beri-beriachtige verschijnselen; het voorschrift is rust, lichamelijk en geestelijk, in een bergklimaat, en als dat niet geeft terugkeer naar Europa.

Onder zich steeds herhalende zenuwpijnen besluit Rouffaer half Mei naar Batavia terug te reizen en dan zoo gauw mogelijk in de Padangsche Bovenlanden te Fort de Kock te gaan uitrusten. Andere plannen zullen moeten vervallen, met name een bezoek aan Bangka, en een met Van Erp op touw gezette oudheidkundige reis over Oost-Java. Kort voor het vertrek geeft een godsdienstoefening in het Augustijner klooster voor het eerst in al die maanden iets van wezenlijke godsdienstige wijding. Allerlei last met het plaatsbespreken op de boot doet de pijnen verergeren, en medicamenten helpen niets. De laatste dagen lijkt het iets beter; en Rouffaer kan althans behoorlijk zijn afscheidsbezoeken brengen. Op 16 Mei vertrekt hij, en is den 21sten te Singapore, om den 28sten Batavia te bereiken.

Daar neemt hij zijn intrek bij zijn vriend Moquette, en blijkt er geen kwestie van dadelijk verder reizen te zijn. Het geneeskundig onderzoek te Batavia bevestigt de noodzakelijkheid van terugkeer naar Europa; het verblijf in Indië zal hoogstens nog een paar maanden in een koel bergklimaat gerekt kunnen worden. Daarmede 
is het verdere reisplan onherroepelijk van de baan, zoodat naar Nederland moet worden geschreven, dat het subsidie van Koloniën, dat op de ontwerp-begrooting voor 1912 stond, niet meer noodig is. Ziek en gedeprimeerd brengt Rouffaer de eerste weken van Juni door in een luien stoel in de voorgalerij, ondanks alles bezig blijvend met lectuur. De voorbeeldige zorgen van den heer en mevrouw Moquette brengen hem spoedig weer wat op zijn verhaal. Dan vraagt een andere zaak zijn aandacht; begin Juni heeft hij de boven reeds even genoemde nota's van den heer Van Vuuren en van den controleur van Atapoepoe over Timor in handen gekregen, en dan schrijft hij om eigen inzicht te verduidelijken en te motiveeren zijn Timor-Nota. Hij sluit deze op $18 \mathrm{Juni}$ af, den dag voor zijn vertrek naar Padang.

De Timor-Nota is een merkwaardig stuk. De strekking is om de toestanden in Portugeesch-Timor te vergelijken met die in Nederlandsch-Timor, en de verhoudingen tusschen beider bestuursambtenaren uiteen te zetten. Het eerste is daarbij aanmerkelijk in het voordeel; de vestigingen, waarvan er 26 werden bezocht, hebben een opvallend netten en daarbij permanenten aanleg, en daar kan ten onzent eigenlijk alleen Koepang zich mede meten; het wegennet is verwonderlijk goed en uitgebreid, en een zeer volledig telefoonnet verbindt de langs de wegen opgerichte posten en postjes onderling en met Dilly; terwijl in Nederlandsch-Timor de wegen zelfs dicht bij Atapoepoe treurig zijn en de eenige telefoonlijn die van Koepang naar Atapoepoe met twee zijlijnen is. Het militaire bestuur der Portugeezen heeft in de harde hand en de zware heerendiensten ook zijn schaduwzijden, die nader verklaard worden, terwijl ten slotte het gebeurde in Lakmaras wordt besproken, niet om een nieuwe lezing van de feiten te geven, maar wel om na te gaan, hoe zoo iets mogelijk kon zijn.

De nota gaat in allerlei details en is wat de personalia aangaat, zeer openhartig. Zij is dan ook niet gepubliceerd, maar heeft haar uitwerking niet gemist, door op allerlei zaken de aandacht te vestigen welke, hetzij men het met Rouffaer eens was of niet, die aandacht ten volle verdienden. Het stuk is niet dadelijk na de vervaardiging ingediend, maar meegenomen naar de Padangsche Bovenlanden en daar nog voorzien van een Naschrift, bevattende een overzicht der economische en andere mogelijkheden voor de eilanden van de residentie Timor, naar orde en belangrijkheid eerst Flores, dan Soembawa, vervolgens Nederlandsch-Timor, daarna Soemba, dan Roti en 
Sawoe, eindelijk de Solor-eilanden en ten slotte Alor en Wetar. In de slot-opmerkingen wordt op de groote toekomst van dit belangrijk gewest gewezen en worden eenige desiderata geformuleerd, telegrafische verbinding, telefoon-aanleg, behoorlijk loopende Gouvernements-stoomers, een officieel voorschrift om de regenmeters te cbserveeren en een gewestelijke bibliotheek. De combinatie van deze vijf punten is voor Rouffaer wel weer heel typisch. Ten aanzien van het laatste punt, de bibliotheek, ook voor de andere gewesten van belang, verklaarde hij zich desgewenscht tot nader advies bereid, en van dat aanbod heeft de Gouverneur-Generaal, juist vóór Rouffaer's vertrek uit Indië, nog gaarne gebruik gemaakt.

Voorloopig zocht hij nu rust in de Padangsche Bovenlanden, hoewel die rust toch maar zeer betrekkelijk blijkt. De boot, 19 Juni van Batavia vertrokken, doet Tĕlok Bĕtong en Bengkoelen aan; in die laatste plaats gaat Rouffaer aan land, nadat hij in den quarantaine-dokter zijn vroegeren gastheer van Ende, dr. Sörensen, heeft weergevonden. Het rondrijden in Bengkoelen, evenals trouwens het heele traject, wordt uitvoerig beschreven; voor opmerken en zich van alles rekenschap geven was Rouffaer niet licht te ziek. Den 23sten is hij te Padang en krijgt er den raad om in plaats van naar Fort de Kock liever naar Pajakombo te gaan. In Padang ook, de ,degelijke achterlands-hoofdplaats”, heeft een vreugdevolle herkenning plaats van den assistent-resident L. C. Westenenk, met wien hij reeds lang in relatie stond in zake de beiden zoozeer ter harte gaande oudheden, en hun gesprek van dien zelfden middag beweegt zich dan ook speciaal op oudheidkundig terrein en vervult Rouffaer van groote verwachting voor de aanstaande samenwerking.

Op 28 Juni gaat de reis naar boven; zeer uitvoerig worden wij over de route en de natuurtafereelen ingelicht, ook over de wijze waarop zijn vreugde in de Minangkabausche huizen wordt getemperd door het schrikbarend gebruik van plaatijzer en blik. In Fort de Kock, waar hij eenige uren stil is, maakt Rouffaer een rondrit, en vindt er zyn ,eersten batoe medjan in volkomen Ngada- (Flores-) type dien ik zelf zie hier in de Bovenlanden, en die evengoed op een of andere plek bij Badjawa zou kunnen staan, zóó absoluut gelijk." Des avonds installeert hij zich in Pajakombo, waar hij het grootste deel van zijn verblijf in de Bovenlanden gebleven is.

Nadat een paar dagen later kapitein Christoffel in hetzelfde hotel zijn intrek is komen nemen, wordt op 3 Juli een autotocht naar Soeliki ondernomen en onderweg bekijkt Rouffaer weer een aantal 
batoe medjan's, die hij later met controleur Groeneveldt opnieuw zal bezoeken en fotografeeren. In dat relaas, midden op den weg naar Soeliki, eindigen plotseling de dagboek-aanteekeningen.

Van de volgende weken kennen wij dus geen bijzonderheden, maar uit allerlei is duidelijk, dat Rouffaer zich voor alles in zijn omgeving levendig bleef interesseeren, al lag over hetgeen hij nog deed ook de droevige schaduw, dat het verzamelde materiaal fragmentarisch zou blijven en het groote samenvattende boek nooit zou geschreven worden.

Ten einde toch nog zoo veel mogelijk te profiteeren van zijn aanwezigheid in de Bovenlanden wat de oudheden anging, heeft hij zijn verblijf de laatste tien dagen van Pajakombo naar Fort Van der Capellen, het middelpunt dier oudheden, verplaatst, en daar, dank zij de krachtdadige hulp van den heer Westenenk, niet minder dan 20 beschreven steenen gevonden in plaats van de verwachte 10, en met men zou bijna zeggen zijn laatste krachten eigenhandig afprenten van die inscripties vervaardigd, één stel voor Batavia en één voor prof. Kern. De heer Westenenk, die sedert met Rouffaer in blijvend contact is gebleven, nam op zich te zijner tijd een inventaris van alle hem bekende oudheden en daardoor tegelijk de gegevens voor een eventueele oudheidkundige kaart van de Bovenlanden te zullen samenstellen ${ }^{1}$ ). Te Fort Van der Capellen is ook, alweder op den dag vóór zijn vertrek, de bovenbedoelde Nota over Gewestelijke Bibliotheken afgesloten. Zij gaat na, wat er op bibliotheekgebied in Indië bestaat, toont dan de noodzakelijkheid van meer gewestelijke bibliotheken aan, bepaalt den omvang van die noodzakelijkheid en wijst de beste wegen aan om aan die noodzakelijkheid te voldoen: óf door bemiddeling van de gemeenteraden óf door het gouvernement, en dan met aankoop der boeken voor aanleg en uitbreiding op aucties in Nederland. Is de zaak eenmaal op gang, dan zal ook particuliere steun, door schenking of erflating, niet achterwege blijven.

En dan is het oogenblik gekomen dat Rouffaer met de Tabanan op 30 Augustus Indië verlaat. Aan boord is hij min of meer patiënt, al schrijft hij ook nog allerlei raadgevingen aan den heer Westenenk over de Sumatraansche oudheden; zijn bedoeling is na aankomst in Europa niet door te gaan naar Nederland, maar eerst in Zwitserland, vermoedelijk Glion, in gezelschap van zijn zuster verdere genezing te zoeken. Volkomen uitgeput bereikt hij op 24 September Marseille.

1) Dit is inderdaad geschied; zie Oudh. Versl. 1912 p. 33. 
Voorloopig is er dan ook geen sprake van verder reizen. Den toestand van de eerste dagen beschrijft hij zelf als een soort van droomleven; lichamelijk volslagen onmacht plus onverzwakte helderheid van geest. Hij bleef dan ook voortdurend te bed of althans op zijn kamer en begon zich pas een dag of tien later zoo te voelen, dat hij weer tot schrijven kon komen, en weer wat eetlust en slaap had. Het plan is dan, ongeveer een maand in Marseille te zijn, daarna via Tanger naar Algeciras te varen en zich rustig in het van ouds bekende Granada neer te zetten, waarvan hij denzelfden heilzamen invloed verwachtte als twintig jaar te voren. Eenig werk heeft hij ook al op het oog: eerst een stuk over Timor voor het Aardrijkskundig Genootschap en dan een Gids-artikel met indrukken van Manila, die hij immers zóó maar op papier behoefde te stellen. Ja, ook werk van grooter omvang wenkte reeds; de Linschoten-Vereeniging had hem al eerder verzocht de Eerste Schipvaart naar OostIndië uit te geven, en dat lokte hem zeer aan, al moest hij vooralsnog in het midden laten, wanneer het zou kunnen. Dat vóór hij iets kon aanpakken een tijd zonder eenige lichamelijke inspanning of geestelijke emotie vooraf zou moeten gaan, daarvan was hij thans zelf ten volle overtuigd. Ook van het Utrechtsche professoraat moest worden afgezien; in 1913 bezette dr. Kohlbrugge dezen leerstoel.

Doch zelfs het bovenbedoelde bescheiden programma kon niet worden verwezenlijkt; Rouffaer was niet meer in staat op eigen gelegenheid verder te reizen, en zoo heeft ten slotte zijn vriend IJzerman zich zijn lot aangetrokken, en heeft hem te Marseille gehaald en naar den Haag gebracht. Daar werd hij in het ziekenhuis van het Roode Kruis opgenomen, en eerst in Januari 1912 kon hij zijn intrek nemen in een pension in de Parkstraat, hetwelk hij ongeveer een jaar later verwisselde voor zijn kamers op Frankenslag 89.

Terwijl hij nog in het Zuiden vertoefde, was het hem een groote voldoening te vernemen, dat het Instituut hem niet vergeten was en er behoefte aan had gevoeld zijn erkentelijkheid te toonen door hem op 21 October te benoemen tot eerelid. Bij die gelegenheid herinnerde de voorzitter, toen prof. Snouck Hurgronje, er aan ${ }^{1}$ ) hoe Rouffaer lange jaren met onovertroffen, belangelooze toewijding de Indische wetenschappen had beoefend, hoe hij bovenal zijn beste

1) Notulen p. IX in Bijdr. 67 (1913). 
krachten aan het Instituut had gegeven en ook gedurende zijn reis aanhoudend de belangen van het Instituut had behartigd. In de Algemeene Vergadering van 1912 was Rouffaer aanwezig en kon hem persoonlijk dank gebracht worden, en bij diezelfde gelegenheid werd hij tot bestuurslid gekozen. Hij is het, met het gebruikelijke jaar tusschenruimte, tot 1920 gebleven. Het spreekt wel vanzelf dat naast het andere dat hij in deze functie verricht heeft, speciaal de belangen der bibliotheek gedurende deze jaren een uitstekend pleitbezorger in hem hebben gevonden.

Vanzelf moest er al spoedig ook weer eenig werk ondernomen worden; nog in de kliniek had hij van de firma Oosthoek bericht ontvangen van de overname van het groote batik-boek, en dus moest er al gauw weer gecorrigeerd worden en wat zulk een uitgave voor verdere beslommeringen meebrengt. In 1913 kwam daar nog een andere publicatie bij; het Instituut ging ter eere van prof. Kern's tachtigsten verjaardag diens Verspreide Geschriften herdrukken, en terwijl telkens voor iedere rubriek verschillende deskundigen zouden optreden, bleef Rouffaer het laatste toezicht op den druk, in overleg met den auteur, houden; een paar jaar later, toen men aan Nederlandsch-Indië toe was, en vooral na het overlijden van prof. Kern, nam hij een nog meer werkdadig aandeel in de samenstelling der uitgave, in het bijzonder bij de inscripties van den Archipel en bij den Nāgarakṛtāgama. Nog in het laatst van 1912 valt de samenstelling, tezamen met prof. Van Vollenhoven, van een eerst later gedrukte nota over het bibliotheek-wezen in West-Indië.

Een ander teeken van zijn toenemend herstel is, dat hij eveneens in 1913 een benoeming tot Voorzitter der Linschoten-Vereeniging kon aanvaarden; na zijn presidiale jaar bleef hij ook hier bestuurslid. Desgelijks zijn sinds halfweg 1913 de notulen der Commissie van Bijstand voor het oudheidkundig onderzoek weder van zijn hand; deze commissie kwam voor moeielijke beslissingen te staan in verband met de uitgave der nieuwe monographie over Baraboedoer, en ook buiten het eigenlijke secretariaat kwam veel van het noodzakelijk overleg op Rouffaer neer. In de tweede helft van dit jaar kwam hij ook weer tot publicaties, al waren het nog slechts kleine stukjes, waaronder de als gewoonlijk zeer uitvoerig gedocumenteerde verklaring van een drietal Maleische woorden voor stoffen; in 1914 volgen er nog een paar. Inmiddels verschijnt in laatstgenoemd jaar het boek over de batikkunst, en wordt Rouffaer's werkkracht wel allermeest ingenomen door de Eerste Schipvaart, bij de uitgave 
waarvan de heer IJzerman zijn medewerker was. Het eerste deel zag in 1915 het licht.

Ziehier dus twee boeken, die Rouffaer's naam op het titelblad met dien van een mede-auteur combineeren. Het voegt in zulke gevallen niet het werk van de beide schrijvers, die zich gezamenlijk voor den inhoud verantwoordelijk stellen, uit elkaar te pluizen, en uit den aard der zaak is het doorgaans onmogelijk beider aandeel aan de voorbereiding van zulk een publicatie te onderkennen. Bij het batikboek staat de zaak echter anders, want het is duidelijk, dat de tekst zelf van de hand van Rouffaer is; hij onderteekent dien trouwens met zijn vollen naam, hij alleen, en spreekt waar het pas geeft ook steeds in het enkelvoud van ,ik” en ,mijn”; ten overvloede zijn de noten, die niet van zijn hand zijn, gekenmerkt door den (J.) van zijn medewerker. Zonder dus in eenig opzicht het aandeel te onderschatten, dat dr. Juynboll in het onderzoek op zichzelf heeft gehad, mag worden geconstateerd, dat de eigenlijke schrijver van het werk Rouffaer is. Bijna geheel is het diens in 1899 begonnen en in 1905 afgesloten geschrift; slechts enkele toevoegingen en een appendixbibliographie zijn van 1913.

Die tekst, in Nederlandsch en Duitsch naast elkander, beslaat niet minder dan 534 folio bladzijden en is weder degelijk gedocumenteerd en veelzijdig als steeds. Het grootste deel ( $389 \mathrm{blz}$.) wordt ingenomen door de in alle details nauwkeurig beschreven techniek, dan volgt de geschiedenis en het verband met de analoge wasteeken- en verfkunst in Zuidoost-Voor-Indië, vervolgens een opsomming van de Javaansche patronen met hun namen, hun zin en hun geschiedenis, en eindelijk de beteekenis voor Indonesië van de Javaansche batik-kunst, technisch, oeconomisch en artistiek, benevens de wisselwerking van deze Oostersche kunstnijverheid met het Westen. De auteur hoopt er toe te hebben medegewerkt om het bewustzijn, dat wij in deze kunst een kostelijken kolonialen schat hebben te zien, tot gemeenschappelijke Nederlandsche overtuiging te maken.

Het ware denkbaar, dat Rouffaer het bij het verschijnen van het boek in 1914 niet meer in alle opzichten eens was met hetgeen hij vijftien jaren tevoren had neergeschreven. Een paar jaar later kreeg hij gelegenheid zijn inzicht nog eens opnieuw samen te vatten in het artikel „Batikken” voor den nieuwen druk der Encyclopaedie van Nederlandsch-Indië. Het is misschien niet ondienstig dit oordeel van den persoon, die meer dan iemand anders in de materie thuis was en er zich voortdurend mee is blijven bezighouden, hier nog even 
kort in herinnering te brengen. Rouffaer dan meent, dat het batikken door Hindoe-emigranten uit Zuidoost-Dekhan in ongeveer 1000 A.D. naar Java werd overgebracht, hier als uitheemsche kunst steeds bleef in hoogere kringen en met het technisch dood-eenvoudige patroon gringsing de wajangpop-idee combineerde, tot de oppermachtig geworden Islam de wajangfiguren deed uitbannen en men bij voorkeur geometrische patronen en bloemmotieven ging gebruiken; in ca. 1850 komt de technisch-economische revolutie met het ook uit Voor-Indië overgenomen tjappen, en in ca. 1900 de technisch-coloristische revolutie met de kunstmatige kleurstoffen. Zoo is er thans veel fabriekmatigs, dat echter tot eigen sfeer, het goedkoope en massale, beperkt dient te blijven; daartegenover zorge het beste inheemsche en uitheemsche intellect, dat de kunst in het Javaansche batikken krachtig in leven blijve.

Ook de bewerking der uitgave van de Eerste Schipvaart was een taak, waaraan Rouffaer zich met groote animo had gewijd; een goed stuk van zijn oude sympathieën was, naar hij zelf schrijft, aan dat werk verknocht, hij voelde zich in deze teksten volkomen thuis, en was het ook zelf geweest, die reeds vroeger het eerst de initialen G. M. A. W. L. volledig had verklaard als die van Willem Lodewycksz, wiens D'Eerste Boeck het in 1915 verschenen eerste deel der uitgave inneemt. Behalve in de voortreffelijke zorg van beide uitgevers voor den herdrukten, of liever gecorrigeerden, tekst van 1598, blijkt hun werkzaamheid uit de vele noten, en menigmaal is het niet moeilijk daarin den stijl van Rouffaer te herkennen; trouwens in die noten stond nog lang niet alles wat er viel op te merken, want herhaaldelijk verwijst een sterretje naar een lateren commentaar. De gunstige ontvangst, allerwege aan deze voortreffelijke publicatie ten deel gevallen, was welverdiend; de ziekte van den eersten bewerker, d.w.z. Rouffaer, had het gereedkomen vertraagd, en met het tweede deel zou dat in nog ernstiger mate het geval zijn.

Een eveneens in 1915 verschenen stukje over Oud-Javaansche eilandnamen in de Groote Oost was minder gelukkig; het lokte de deskundige kritiek uit van dr. Van Ronkel, die ook vroeger al eens zijn stem had verheven tegen iets wat Rouffaer op het hem dan ook geheel vreemde terrein der taalwetenschap had ten beste gegeven. Rouffaer, die juist aan zijn gissingen op een gebied, waar hij minder dan elders meester was, bijzonder hechtte, was door die kritiek eerst teleurgesteld, ook wel wat ongeloovig, tot dat een rechtstreeksche 
vraag aan dr. Adriani hem had geleerd, dat het ongelijk zonder eenigen twijfel aan zijn eigen zijde was. Maar toen heeft hij er zich dan ook zonder eenige reserve bij neergelegd. Het was een zijner meest sympathieke eigenschappen, ook in andere gevallen die het niet tot den druk brachten duidelijk aan het licht tredend, dat hij, hoe ook het opgeven van lang gekoesterde theorieën of met vreugde begroete ontdekkingen hem aan het hart mocht gaan, geen oogenblik van aarzeling kende, zoodra hij eenmaal overtuigg was wat de waarheid eischte. Zonder ooit zijn standpunt op te geven vóór het noodzakelijk was, heeft hij altijd voor de tegen hem aangevoerde argumenten een open oor gehad. Maar makkelijk is het erkennen van de onhoudbaarheid van eigen inzicht hem daarom toch niet geweest, en in het geval van de eilandnamen zeer zeker niet.

Van Rouffaer's onverzwakt streven in het belang van zijn Koloniale Bibliotheek geven de Instituuts-notulen van 1915 nog weder eens blijk. Als hij in een bestuursvergadering ankoop van boeken voorstelt, vestigt de nieuwe secretaris - dr. Kielstra is dan juist afgetreden -- de aandacht op de vigeerende bepalingen, die zulke aankoopen aan den bibliothecaris-secretaris overlaten; m. a. w. Rouffaer gaat met die voorstellen buiten zijn boekje. Geen nood, hij stelt een nieuwe bepaling voor, en ziet die met eenige wijziging ook aangenomen, dat het bestuur eveneens, den bibliothecaris gehoord, aankoopen kan vaststellen. ${ }^{1}$ ) Aanleiding om tot zulk een vaststelling het initiatief te nemen heeft hij dikwijls gevonden, en als dan uit geldelijke of andere overwegingen het bestuur voor zijn smeekbeden doof moest blijven, is hij als vanouds in eigen buidel gaan tasten of heeft anderen er toe gebracht het boekwerk in kwestie te schenken. Ook na zijn aftreden als bestuurslid is hij op deze wijze de bibliotheek blijven verrijken.

Over een geheel nieuw plan om met steun van het Instituut de Indische letteren te bevorderen, leest men in datzelfde deel der Instituuts-notulen. ${ }^{2}$ ) Het betrof de uitgave van een zoogenaamde Bibliotheca Neerlando-Indica, een serie inlandsche teksten met beknopte inleiding en min of meer uitvoerige Nederlandsche inhoudsopgave; de bedoeling was om eenerzijds voor ontwikkelde inlanders belangrijke voortbrengselen hunner litteratuur gemakkelijk toegankelijk te maken, anderzijds ook belangstellende Nederlanders te bereiken. Het denkbeeld vond in den kleinen kring van deskundigen,

1) Pag. XV, XVII en XIX in Bijdr. 71 (1916).

2) Ibid. p. XXIX en XLI, en 1916 p. V, X en XXIV (Bijdr. 72). 
aan welke het eerst ter overweging was gegeven, geen onverdeelden bijval; in een ruimer groep van belangstellenden, tot een bespreking opgeroepen, bleek de sympathie grooter, en in beginsel werd tot de uitgave van zulk een serie besloten. Een paar aanwezigen namen de bewerking van een deeltje op zich, maar bij die bereidwilligheid is het gebleven. Rouffaer heeft l:laarblijkelijk begrepen, dat hij in zijn overtuiging van de noodzakelijkheid der uitgave vrijwel alleen stond temidden van degenen, die haar hoogstens wenschelijk achtten; hij is verder niet meer op de zaak teruggekomen dan om, toen zijn gezondheid minder gunstig was, uit de slapende commissie ad hoc zijn ontslag te verzoeken. Op den duur bleek trouwens, dat de uitbreiding van de werkzaamheden der Commissie voor de Volkslectuur te Weltevreden het voorgenomen werk in Nederland overbodig maakte. Een ander plan van Rouffaer, dat wel tot resultaten leidde, was de door hem in de Nieuwe Rotterdamsche Courant van oudejaar 1915 geopperde wensch, nader in een voorstel belichaamd bij het Instituuts-bestuur, om een goed geillustreerd, overzichtelijk werk te doen schrijven over de Hindoe-Javaansche kunst, waaromtrent sedert het optreden van Brandes zooveel meer bekend was geworden. De in 1919 als Instituuts-uitgave verschenen „Inleiding tot de Hindoe-Javaansche kunst" was van een en ander het gevolg. ${ }^{1}$ )

Hierboven was reeds even sprake van den tweeden druk der Encyclopaedie van Nederlandsch-Indië, waarbij ook Rouffaer weder tot de medewerkers behoorde; niet in alle opzichten overeenkomstig zijn eigen wenschen, want buiten hem om werden stukken, die hijzelf in den eersten druk bezorgd had, thans aan anderen ter bewerking gegeven. Toch staat er nog heel wat van hem in; de lijst daarvan vindt men in de bibliographie. Het eerste deel verscheen in 1917, de andere achtereenvolgens in 1918, 1919 en 1921. Wij noemden reeds het artikel „Batikken”; bijzondere vermelding verdient ook dat over „Keteltrommen (bronzen)”, omdat hij er voor het eerst de verspreide gegevens over deze merkwaardige oudheden volledig samenvat en er zijn conclusie over afkomst en gebruik uit trekt, waarvan hij terecht getuigt, dat ze ,goeddeels nog nergens vermeld” zijn: de echte ,reuzentrommen” zijn tusschen ca. 100 en 600 A.D. uit ZuidChina en Achter-Indië ingevoerd, deels als poesaka, deels door oude Pegoeanen, waarbij dan het stervormig ornament als kompas ver-

1) Over dezen gang van zaken kan men het Voorbericht van genoemd boek raadplegen. 
klaard kan worden; op Java, waar ze in de verbeelding tot helleketels werden, zijn ze dan later eenigszins af wijkend nagemaakt. Ook de andere artikelen, in het bijzonder de biographische, bevatten allerlei belangrijke en dikwijls nieuwe bijzonderheden, zelfs waar de gevolgtrekkingen (als b.v. in het artikel Pegoeanen) wel wat te gewaagd schijnen om dadelijk aanvaard te worden.

Een bewaard gebleven correspondentie met de redactie der Encyclopaedie doet blijken, dat behalve de met de letters G. P. R. onderteekende ook nog andere artikelen van zijn hand zijn; de voornaamste worden hierachter vermeld. Ook stukken van anderen kreeg hij op zijn verzoek wel eens ter inzage en gaf dan verbeteringen in overweging. Maar de reeds vroeger besproken eigenaardigheid om moeielijk zijn pennevruchten als geheel persklaar te kunnen afleveren en ze steeds ter vervolmaking aan te houden, leidde ook hier tot conflicten. Rouffaer was niet op tijd, en wanneer de redactie dan voorstelde zijn artikelen uit den eersten druk ongewijzigd over te nemen, verbood hij dit pertinent. Als echter de redactie met zulke voorstellen gehoopt heeft hem aan het schrijven of afleveren te krijgen, is zij bedrogen uitgekomen. Het conflict verscherpte zich, toen Rouffaer een andere regeling van het honorarium verlangde en de uitgever daar niet op in wenschte te gaan, en het slot was dat Rouffaer geen verdere medewerking verleende. Dientengevolge zijn een aantal belangrijke artikelen (men kan dat reeds eenigszins opmaken uit de titels: Bocarro, Couto, Correa, Gadjah mati, Giri, Goenoeng Djati, Moesson-boeken) in portefeuille gebleven. Een paar andere waren oorspronkelijk veel langer dan ze opgenomen zijn. De correspondentie kwam eerst in 1923 tot een einde.

Zijn langzamerhand minder gunstig wordende gezondheidstoestand maakte, dat zijn publicaties in deze jaren zich hoofdzakelijk tot het werk voor de Encyclopaedie beperkten. Onder de parerga is echter een artikel van een heel bijzonderen aard, omdat het een der weinige is, waarin Rouffaer zijn gevoel doet spreken: de herdenking van Charles te Mechelen. Onzes inziens een van de mooiste en gaafste stukken, die Rouffaer heeft geschreven; het leven van $\mathrm{Te}$ Mechelen zóó geschetst, dat alle feiten van beteekenis vermeld worden en er toch niets overbodigs in staat, zijn beeld zóó geteekend, dat men het, door de allerminst verzwegen tekortkomingen heen, gaat zien met dezelfde sympathie als de beschrijver. Op deze acht bladzijden vol begrijpende genegenheid is in Rouffaer de vriend en de dichter aan het woord. Ook in een ander stukje in hetzelfde tijd- 
schrift klinkt, bij de aankondiging van Nieuwenkamp's vierde reis naar onze Oost, een zeer persoonlijke noot. Maar bij Te Mechelen is het toch nog anders. Komt het omdat deze tevens de ,representant uit duizenden" was van een bekoorlijk stuk van Java's voorbijgegane, nooit terugkeerende periode, waarvan ook Rouffaer zelf alle poëzie had gevoeld? Ziehier hoe hij de ingetreden verandering schetst:

„De wajang, dat echt-Javaansch gewrocht van in eigen geest gegroeide fantasie, verdwijnend uit het volksbesef ; op smadelijke wijze overwonnen door het vulgair-technische van den Europeeschen bioscoop, de „levende beelden” (gambar hidoep), zooals de inlanders in hun naive verdwazing dit kermis-gedoe der Westersche beschaafdheid in den aanvang dadelijk doopten. De Javaansche hormat, zwaar geurende Oostersche bloem van eigen bodem, maar bloem dan ook van geur als kĕnanga en van grillig-strakke vormen als een orchidee, ontluisterd meer en meer door een gemoedsverandering die in veel opzichten gemoedsverruwing was. De stille poëzie van de Javaansche desa, de weemoedige nachtklank der gamĕlan, aangetast en verstoord door rumoer uit het Westen in Oostersche hersenen overgezaaid; meestal slechts overgewaaid ... Hij voelde niets voor dit groeiproces van ,inlander" tot Indonesiër, waarvan hij het geestesverlies maar al te diep besefte, de geesteswinst betwijfelde, de onafwendbare noodzaak van óók dit natuurproces niet vatten kon noch vatten wou."

Dergelijk proza bewijst, dat in en achter den wetenschappelijken onderzoeker ook de schrijver der Spaansche indrukken nog leefde. Naar buiten geuit heeft deze kant van zijn geest, dien slechts weinigen vermoedden en die toch in het vriendschappelijk onderhoud zoo sterk kon spreken, zich later echter niet meer.

Evenzeer klein van omvang maar belangrijk van inhoud is hetgeen Rouffaer schreef in den Gids der in 1917 geopende Verzameling van Indonesische en Chineesche kunst te Leeuwarden. Die verzameling was hem bekend; het was de collectie, indertijd door den heer A. T. van der Meulen bijeengebracht en opgesteld te Bergum. Rouffaer had er in 1906 over geschreven en toen zijn ingenomenheid betuigd over de wijze waarop men de verschillende voorwerpen werkelijk kon zien, vooral doordat bij de opstelling gebruik gemaakt was van kleine, intieme kabinetten. Bij de overbrenging naar Leeuwarden gaf hij eenige beschouwingen over Chineesche invloeden op Javaansche kunst, aanknoopende bij een gebeeldhouwden steen van het land Tjilintjing bij Batavia, een ,verrukkelijk staaltje van Hindoe- 
javaansch-Chineesch syncretisme", dat hij bij een tochtje in December 1909 had opgemerkt.

De nieuwe opstelling der collectie had zooveel mogelijk plaats volgens de principes van die kunstbeoefenaars, welke in het voorjaar van 1918 een middelpunt van werkzaamheid vonden in de toen opgerichte Vereeniging van Vrienden der Aziatische kunst. Ook Rouffaer behoorde tot dien kring en had er gezag zoowel bij de mannen van de ,kunst” als bij die van de ,wetenschap”. Toen de inzichten van die beide groepen inzake de wenschelijkheid van een afzonderlijk kunst-museum uiteen bleken te loopen, was hij het dan ook, die poogde de scherpe kanten der tegenstelling te verzachten. Voor zijn - tenslotte vergeefsch - pogen is ieder hem dankbaar geweest. Zijn gezondheidstoestand heeft hem echter spoedig het bestuurslidmaatschap doen nederleggen.

Ook met speciaal oudheidkundig onderzoek begon hij zich na een lange tusschenruimte weer bezig te houden. De eerste vruchten daarvan zijn de "Oudheidkundige opmerkingen” in de Bijdragen van 1918, een vijftal kleine stukjes, niet alle even overtuigend, maar vol origineele gezichtspunten. Spoedig daarna kwam er aanleiding voor een werk van grooter omvang en wijder strekking. In het voorjaar van 1919 verscheen, als overdruk uit het Journal Asiatique, de studie van Gabriel Ferrand over „Malaka, le Malāyu et Malāyur”. Met de conclusie van Ferrand, het bestaan tusschen ca. 800 en 1400 van twee Malayu's, één op Sumatra en één gelijk aan Malaka, was Rouffaer het allerminst eens, en al heel gauw bekroop hem de lust er iets tegen te schrijven. Het zou een klein stukje van een twintig bladzijden zijn. Hoe weinig kende hij zichzelven! Toen hij zich eenmaal weder had verdiept in het hem van ouds ter harte gaande onderwerp der vroegste geschiedenis van Sumatra en het Maleische Schiereiland, volgde het een op het ander, en zoo zijn ten slotte de 20 bladzijden er 420 geworden.

Zonder moeite is dit boek - want hoewel het in twee stukken werd opgenomen in de Bijdragen, kan men beter van een boek dan van een tijdschriftartikel spreken - niet tot stand gekomen. Immers juist in den tijd dat hij er mee bezig was, begon zijn gezondheidstoestand zoo verontrustend te worden, dat hij zich genoopt voelde van al zijn openbare functies afstand te doen. Gemakkelijk is hem dat natuurlijk niet gevallen, en zeker niet wat het Instituut betrof, waar hij tengevolge van zijn bestuurswerkzaamheid zooveel ten behoeve van de bibliotheek en van andere wetenschappelijke Indische D1. 84. 
belangen kon doen. Maar hij begreep dat het moest, en in zulk een geval was aarzelen hem vreemd. Ook zag hij in, dat half werk geen zin had en dus trok hij zich algeheel terug: uit de besturen van Linschoten-Vereeniging en Vrienden der Aziatische kunst, maar ook uit het Instituuts-bestuur, het secretariaat der Commissie van Bijstand voor het Oudheidkundig Onderzoek, en de verzorging van Kern's Verspreide Geschriften. Hij was er zich volkomen van bewust, dat het geen tijdelijke maatregel, maar een afscheid voor goed was.

Het is natuurlijk niet toevallig, dat hij juist in dezen tijd ook andere beschikkingen trof, en aan een deel van zijn kunstbezit een bestemming gaf. Een en ander kwam vooral ten goede aan Rotterdam. In het Museum Boymans werden een viertal kleine schilderijtjes opgenomen, de vier zintuigen: gehoor, gezicht, reuk en smaak voorstellend en toegeschreven aan Molenaer; later bleek dat de serie ten rechte is vervaardigd door v. d. Merck. Daarnevens schonk Rouffaer een fraai winterlandschap van Iodocus de Momper en een batik ${ }^{1}$ ).

De groote collectie op het gebied der weefsels kwam echter, gelijk begrijpelijk is, niet in Boymans doch in het Museum voor Land- en Volkenkunde en Maritiem Museum „Prins Hendrik”. De keus van dit Rotterdamsche museum lag voor de hand, niet alleen omdat het juist op het gebied der Indonesische weefsels bijzonder goed voorzien is en het geschenk er onder deskundige verzorging het best tot zijn recht zou komen, maar ook uit hoofde van Rouffaer's persoonlijke relatie tot den directeur, den heer J. W. van Nouhuys, met wien hij in 1909 te Batavia het eerst in aanraking was gekomen, en die, sinds zijn terugkeer uit Indië in 1915, tot Rouffaer's beste persoonlijke vrienden was gaan behooren. De collectie, in het museumverslag over 1920 nader beschreven ${ }^{2}$ ), omvatte een groot gedeelte van het studie-materiaal voor het boek over de batikkunst, daarbij een aantal hoogst belangrijke stukken, en ook nog andere voorwerpen op ethnographisch gebied. In 1921 en 1924 hadden nog eenige schenkingen plaats; wat hij gaarne in zijn nabijheid hield, zou na zijn dood volgen.

Zoo begint dan met den aanvang van 1920 het laatste stuk van Rouffaer's leven, grootendeels op zijn kamer doorgebracht, eerst nog op het Frankenslag, en sinds September vaì datzelfde jaar in de

1) De directie is zoo vriendelijk te verwijzen naar Cat. 1921 no. 294 en Cat. 1927 no. 281 en 298.

2) Zie pag. 4-7. Rouffaer zelf had alles van nauwkeurige aanteekeningen voorzien. 
Van Bleiswijkstraat $71 \mathrm{~F}$, waarheen hij tezamen met de familie, bij welke hij kamers had, verhuisde, en waar hij op de tweede verdieping het naar omstandigheden zoo goed mogelijk had, dank zij mede de toegewijde verzorging door mej. D. Dun. Daar zat hij dan, zoo mogelijk heele dagen, en anders zooveel als zijn toestand gedoogde, achter de schrijftafel of op zijn makkelijken rieten stoel (die hem sinds zijn studententijd voortdurend, ook op reis, heeft vergezeld) en was er steeds met een of ander wetenschappelijk onderzoek bezig. Veelzijdig bleef zijn belangstelling en ook in de maanden dat hij aan een bepaalde studie zijn krachten grootendeels moest wijden, was er tijd voor andere onderwerpen daartusschenin. De scherpte van zijn geest bleef onverzwakt, alleen werd het tempo zijner productiviteit langzamer; hij had dus meer tijd noodig om hetzelfde quantum werk te verzetten als vroeger, doch de resultaten verminderden gelukkig niet in gehalte. Het bezoek zijner vrienden was een op prijs gestelde onderbreking, en hoewel natuurlijk aan beiderzijdsche particuliere aangelegenheden ook wel aandacht werd geschonken, vormden toch informaties naar en mededeelingen over studie en onderzoek den hoofdinhoud van het gesprek. Hij had dan altijd een heele lijst van vraagpunten klaar liggen, en op hoe velerlei gebied kon hij niet als deskundige meespreken! Het waren daarbij volstrekt niet alleen de oude bekenden, uit Nederland en Indië, die hem kwamen opzoeken; ook menig jongere wendde zich tot deze bron van wetenswaardigheden, waaruit hem met de grootste gulheid en onbekrompenheid werd veroorloofd te putten, en waar hij altijd nog meer kon vinden dan hij had verwacht.

Wie het tot stand komen van het stuk over Malaka van nabij heeft gevolgd, het langs een weg, welks telkens nieuwe uitzichten en zijpaden den auteur zelf niet weinig verbaasden, heeft zien komen tot voorloopig persklaren toestand, om het daarna de door onophoudelijke verbeteringen en toevoegingen bemoeilijkte instanties van proeven en revisies te zien doorloopen, verwondert er zich eigenlijk over, dat het ooit werkelijk afgedrukt is (Bijdragen van 1921). Het vertoont in de grootste mate de verdiensten en de schaduwzijden van Rouffaer's wetenschappelijke werkwijze. Het bevat schitterende bewijsvoeringen, die lang betwiste punten met één slag voor goed oplossen, naast gewaagde, soms zelfs onverantwoordelijke gissingen; het geeft voortreffelijk gecomponeerde samenvatting van detail-onderzoek, maar dikwijls in een zóó moeielijk te volgen verband, dat men er ook na herhaalde lezing van het stuk veelal niet in slaagt bepaalde punten 
terug te vinden. Alles te zamen in ieder geval een artikel van buitengemeene kwaliteiten, een van de soort, waarop Rouffaer zelf het epitheton ,kranig” toepaste.

Van den inhoud geeft de lange titel: „Was Malaka emporium vóór 1400 A. D., genaamd Malajoer? En waar lag Woerawari, MāHasin, Langka, Batoesawar ?" reeds eenig denkbeeld. De ondertitels der beide deelen, waarin het opstel is gesplitst, verduidelijken dat nog; het eerste heeft tot inhoud: ,Malajoer is niet Malaka, doch Djambi ; Woerawari $=$ Langka $=$ Djohor $;($ Mā-)Hasin $=$ Toemasik $=$ Singapore”, en het tweede gedeelte: „Oudheden ter Zuidhelft van Malaya; opvaart der Djohor-rivier; Batoesawar, de bakermat der Sadjarah Mĕlajoe, 1612-'14 A. D." Maar het is er verre vandaan, dat zelfs deze uitvoerige titulatuur den werkelijken inhoud van het boek zou bestrijken. De afdoende wederlegging van Ferrand, welke inderdaad binnen de perken der voorgenomen twintig bladzijden blijft, leidt vanzelf tot de vraag, wanneer Malaka dan wèl gesticht is, en die vraag kan slechts beantwoord worden door kennis te nemen van alle oude berichten over de Zuidelijke helft van het Maleische Schiereiland, in de eerste plaats over het in de verhalen over Malaka genoemde Singapore. Een voorname bron had de verloren geganc rotsinscriptie van Singapore kunnen zijn, en daaraan wordt dan een uitvoerig relaas over dien steen en zijn vernieling vastgeknoopt. Het heeft geen zin hier na te gaan, hoe de verschillende in de titels genoemde plaatsnamen in hun verband met de Maleische oude geschiedenis worden gebracht; de gelijkstelling van Langka met Djohor en de tegenstelling tot het Java van koning Erlangga geeft aanleiding tot het toekennen van een symboliek-politieke beteekenis aan de reliefs van Prambanan en aan de Javaansche rijkssieraden; daaraan hebben wij dan weer een uitgebreide verhandeling over deze oepatjara te danken, en op deze wijze kon Rouffaer tevens zijn reeds vroeger dienaangaande bijeengebrachte gegevens (bestemd voor het Encyclopaedie-artikel over Beeldende Kunst) tot hun recht doen komen. Een nader overzicht van de verdere plaatselijke geschiedenis in de dertiende en veertiende eeuw besluit het eerste deel. Overal, in den tekst en in de vele noten, is er gelegenheid te over voor scherpzinnige redeneeringen en fantastische hypothesen.

Het tweede deel, dat met een fraaie beschouwing over oud-Singapore en den zeeweg aanvangt, wordt grootendeels ingenomen door het nauwkeurig volgen en commentarieeren van de reis over de Djohor-rivier, in 1826 ondernomen door iemand, die zich Viator 
noemt, maar volgens Rouffaer niemand anders kan zijn dan de bekende John Crawfurd. Dat geeft allerlei aanknoopingspunten met de geschiedenis der sultans van Djohor, daaronder begrepen het ontstaan der Sadjarah Mĕlajoe; dit laatste betoog, waarmede Rouffaer zelf zeer ingenomen was en dat hij dan ook expresselijk in den ondertitel vermeldde, heeft echter bij deskundige beoordeelaars geen genade gevonden. Als de opvaart der rivier tot den Běloemoet gevolgd is, brengt de naam Tjĕnakoe den auteur op de Měnangkabausche Tjaniago, en zoo op de Mĕnangkabausche oude geschiedenis in het algemeen, en de kolonisatie in de Něgri Sĕmbilan. Lijvige bijlagen over de Malaksche antiquiteiten en over de vorsten van Malaka en Djohor, beiden de eerste volledige samenvatting gevend van het beschikbare materiaal, besluiten het artikel. Het is begrijpelijk, dat een der beoordeelaars zich ,verbijsterd" erkende; maar bewondering voor een geweldigen arbeid is toch in bevoegde kringen de hoofdindruk geweest. Ook als men al het twijfelachtige aftrekt, is er een zeer groote stap voorwaarts gedaan.

Toen de schrijver de overdrukken rondzond, kon hij op den omslag laten zetten: dr. G. P. Rouffaer. Op 13 October 1921 toch had de Leidsche Universiteit hem het eere-doctoraat in de letteren en wijsbegeerte verleend. Hoe weinig gesteld hij in het algemeen ook op eerbetoon was, een dergelijke openbare erkenning van zijn wetenschappelijke verdiensten moest hem wel zeer aangenaam zijn, en het gaf meteen het duidelijk bewijs, dat, wie in zijn werk ook dat van den "dilettant" mocht zien (en dat was het geval bij menschen, die hem overigens zeer genegen waren), de vertegenwoordigers der wetenschap zelve dat zeer zeker niet deden. Niet minder voldoening lag er voor hem opgesloten in den gelukwensch van den rector magnificus, toevallig in dat jaar juist een zoo bevoegd autoriteit als prof. Snouck Hurgronje. „Bij deze gelegenheid moet ik er toch nog even weer van getuigen”, schreef deze:,,wat Gij deels door voortdurende eigen inspanning, deels door prikkeling van de energie van anderen, bovenal door Uw schitterend voorbeeld van belanglooze toewijding, voor de wetenschap van Indië verricht hebt, wordt door niemand overtroffen". Zulk een waardeering van zulk een beoordeelaar heeft hem innig goedgedaan. Zijn krachten lieten hem niet toe zich aan een openbare academische plechtigheid te wagen, en dus werd de doctorsbul hem ten zijnen huize door den rector en den promotor prof. Colenbrander overhandigd.

Dat het met zijn gezondheid, niettegenstaande vleugjes van zich 
beter voelen, steeds minder werd, moest voor ieder, ook voor hemzelf, duidelijk zijn. Nog twee dingen heeft hij kunnen publiceeren, beide in 1923. Het eerste is een kort artikel in de Bijdragen, waarin op scherpzinnige wijze wordt bewezen, dat de drie anonymi, welke in het Tijdschrift voor Ned.-Indië van 1857 en volgende jaren belangrijke mededeelingen van hoofdzakelijk archaeologischen aard leverden naar aanleiding van een reis over Midden-Java in (1839 of) 1840, niet anders zijn, en niet anders kunnen zijn, dan de ééne dr. W. R. van Hoëvell. Het belang dier mededeelingen wordt, nu wij weten van wien ze afkomstig zijn, niet weinig verhoogd. Het tweede stuk draagt den vorm van een Naschrift op de beschrijving, die de controleur Van Suchtelen in het maandblad "Nederlandsch-Indië, Oud en Nieuw” had gegeven van het oud-Portugeesche fort op Ende. Dat naschrift bevat vooreerst de bespreking van een paar nieuw gevonden antieke gegevens over de situatie van dat fort, met reproducties uit Parijsche en Londensche handschriften, en vervolgens een Chronologie der Dominikaner-missie op Solor en Flores (ca. 1556-1638) en Bibliographie over het Ende-fort. Vermoedelijk hebben de lezers van dit als populair bedoelde tijdschrift wel wat vreemd opgekeken over al deze bladzijden chronologische en bibliographische aanteekeningen, maar hoezeer is het wetenschappelijk onderzoek gebaat door Rouffaer's werk; dit nauwkeurig en volledig, tevens kritisch, overzicht van alle, kerkelijke en wereldlijke, bronnen, was iets dat hij alleen vermocht samen te stellen. Het sluit zijn publicaties op waardige wijze af, en niets zou doen vermoeden dat de auteur, zóó in het volle bezit van waarlijk buitengewone geestelijke vermogens, reeds den dreigenden ondergang nabij was.

Thans restte nog het tweede deel der Eerste Schipvaart, dat de oudste journalen moest bevatten. Langzaam kwam het gereed; de rijke Inleiding is in Maart 1925 afgesloten. Ook verder vertoont het boek de voortreffelijke kwaliteiten van het eerste deel en overeenkomstige belangrijke noten. Rouffaer zelf heeft het niet geheel meer kunnen fiatteeren; ook bij dit laatste werk viel het hem zwaar de proeven definitief uit handen te geven, en zijn gezondheid liet hem niet toe er vlot aan door te werken. Zoo heeft ten slotte de tweede bewerker, dr. IJzerman, den druk tot een goed einde gebracht.

Inmiddels wisselden periodes van inzinking met tijden van betrekkelijken welstand af. Een auto-tocht naar Delft gaf gelegenheid om de nieuwe gebouwen der Technische Hoogeschool en de vele veranderingen in de hulpmiddelen bij de ingenieursopleiding met ver- 
bazing en ingenomenheid waar te nemen; bijzonder genoot Rouffaer ook van een eveneens per auto ondernomen uitstapje naar Amsterdam in het najaar van 1925 om er de tentoonstelling van Chineesche kunst te bezichtigen, ingericht door de Vereeniging van Vrienden der Aziatische Kunst.

In Februari 1926 was een val de aanleiding tot een onderzoek in het ziekenhuis, en hoewel die val op zichzelf geen kwade gevolgen bleek te hebben gehad, werd het toch wenschelijk gevonden Rouffaer voor eenigen tijd op te nemen in „Villa Elisabeth”. Daar echter openbaarden zich de heel wat erger verschijnselen van geestelijke afwijking, zoodat tegen het eind van die maand overbrenging naar Oud-Rozenburg noodzakelijk werd; Rouffaer was toen zoozeer van zinnen, dat hij zich van die overbrenging niet bewust was. Maar al spoedig verbeterde de toestand, en eind April kwam Rouffaer hersteld weer thuis; zijn eerste werk, toen hij er het inmiddels voltooide tweede deel der Eerste Schipvaart vond liggen, was te constateeren, dat niet alle correcties geheel overeenkomstig zijn wensch waren uitgevoerd.

Voorloopig ging het goed, tot ongeveer half Juli. In dezen tijd is de laatste correspondentie gedateerd en is ook de laatste wetenschappelijke aanteekening neergeschreven, waarop hij, gelijk hij dat zoonoodig deed, een datum zette: dit was eind Juni en had betrekking op het planten van den nieuwen heiligen waringin op de Noorder aloen-aloen te Jogja. Maar toen was toch het eind van alle wetenschappelijke werkzaamheid nabij. Lichamelijk leek de toestand niet onbevredigend, maar wie hem spraken, bemerkten toch het vreemde in zijn optreden, zich onder meer uitend in het ondernemen van groote auto-tochten, soms tot diep in den nacht. Op die wijze is hij nog naar Rotterdam en naar Leiden gekomen.

Laatstbedoelde tocht geschiedde op den dag vóór de tweede en nu definitieve overbrenging naar Oud-Rozenburg, op 31 Augustus. Thans was hij zich ter dege van de beteekenis van dit feit bewust en ging er zeer onder gebukt; een kleine lichtstraal bracht de ontvangst, juist na zijn opname, van een telegrafischen groet uit Nieuw-Guinea, van de boven de Rouffaer-rivier angekomen expeditie-Docters van Leeuwen. Ruim zestien maanden heeft dit laatste verblijf op OudRozenburg nog geduurd. Alras verminderde Rouffaer's lichamelijk weerstandsvermogen en het laatste jaar heeft hij grootendeels op bed doorgebracht. Voor zichzelf voelde hij zich niet bepaald ongelukkig en hij beklaagde zich dan ook nooit over de behandeling; wel had 
hij sterk het gevoel opgeborgen te zijn en nam hij dit dengenen, die hij er verantwoordelijk voor achtte, geducht kwalijk. Maar het zou meende hij slechts tijdelijk zijn, en hij was al weer bezig allerlei plannen te maken voor reizen naar Italië en Spanje.

Onder de enkele vrienden, die hem bleven bezoeken, was het vooral de heer Teillers, thans weder in Nederland terug, tot wien hij zich in de laatste jaren bijzonder aangetrokken gevoelde. Kans op verbetering was er niet, en terwijl hij zich er goed rekenschap van kon geven, wat er aan andere patiënten ontbrak, bleef de omfloersing van eigen geest voortduren om niet meer te wijken, onder blijvende lichamelijke verzwakking. Heel langzaam ging het achteruit, tot in de eerste dagen van 1928 een snelle verergering intrad.

Zondag 8 Januari 1928 overleed hij, 67 jaar oud. Den Donderdag daarop werd hij, overeenkomstig zijn wensch in allen eenvoud, op het kerkhof te Diepenveen nabij het graf zijner geliefde zuster ter ruste gelegd.

Rouffaer's uiterlijken levensloop en zijn wetenschappelijk werk hebben wij trachten te schetsen, met eenige uitvoerigheid, zooals hij die zelf in een levensbericht gepast achtte. Daarbij werden vanzelf veel van zijn eigenaardige karaktertrekken aangeroerd, maar wij zijn er ons maar al te zeer van bewust, dat het heel bijzondere van deze figuur er toch niet tot zijn recht kwam. Naast Rouffaer als wetenschappelijk onderzoeker ook iets van Rouffaer als persoonlijkheid te laten zien, is wel heel moeielijk; het lijkt onmogelijk om voor wie hem niet gekend hebben, van deze zoo bij uitstek levende, geestelijk levende, figuur een indruk te geven door het geschreven woord, en voor wie hem wel kenden zal het noodzakelijkerwijs een maar al te flauwe afschaduwing van de werkelijkheid blijven.

Doch al zullen wij ons dan ook niet wagen aan de ijdele poging om het volledig beeld van Rouffaer als persoon vast te leggen, wij mogen ons niet onttrekken aan de taak om toch nog eenigermate te verduidelijken, wat zijn bijzondere kracht was. In zekeren zin heeft prof. Snouck Hurgronje dat al in zijn gelukwensch van 1921 geformuleerd, als hij naast de eigen inspanning van den nieuwen doctor diens prikkelen van anderer energie maar bovenal zijn voorbeeld van belangelooze toewijding roemt.

De eigen inspanning en de vruchten daarvan treden het eerst en het duidelijkst naar buiten, en er is hierboven juist daarvan het meeste sprake geweest. De Koloniale Bibliotheek en de statige reeks 
artikelen en boeken zijn de bewijzen van een onvermoeide en tot voortreffelijke resultaten leidende wetenschappelijke werkzaamheid. „Wie aan Rouffaer denkt”, aldus vangt prof. Van Eerde de herdenking aan, die hij in het Tijdschrift van het Aardrijkskundig Genootschap aan den overledene wijdde ${ }^{1}$ ), ,ziet een werker, een vorscher, een schrijver, een veelweter, die altijd verder zocht; die bij elk voor hem nieuw gegeven ook dat weder gesteund wilde zien op andere gegevens. Een, die nooit klaar was, voor wien steeds nieuwe verschieten van kennis zich openden, die ontroerd was bij de ontdekking van voor hem nieuwe vondsten, die genoot van het vinden van steun voor bestaande opvattingen.” En iets verder: ,in zijn hart gloeide het vuur van den vorscher en den ontdekker van den Indischen Archipel." Dat is inderdaad zooals Rouffaer het voelde, gelijk hij aan het slot van den Tijdzang den roep van „Land!” ook tot zichzelf gericht achtte.

Daarnaast een uitspraak over Rouffaer's wetenschappelijk werk van den vertegenwoordiger van een geheel anderen tak van wetenschap, prof. Van Vollenhoven ${ }^{2}$ ). „Kenmerkend zijn een uitnemende speurzin, die niets op gezag aanneemt en overal kleinigheden van gewicht weet te ontdekken; een doordringen in dingen en menschen van voorheen, hetwelk b.v. auteurs, die boektitels plegen te blijven, als levende menschen ziet en treffend weet te kenschetsen; en een soms te welige - gaaf van gissing, die meermalen op goed spoor brengt."

Deze beide oordeelen karakteriseeren Rouffaer's wijze van werken en wat hij er mede bereikte. Zij geven ook te verstaan, waarom een dergelijk arbeiden schaduwzijden moest vertoonen, die wij in het voorafgaande niet hebben verzwegen. Deze „vrije geleerde” was ten slotte al te vrij; hij voelde geen enkele noodzakelijkheid om uit het vele, dat gelijke aanspraken op zijn belangstelling scheen te hebben, het eene te kiezen en het andere te verwaarloozen, maar wijdde zijn krachten aan alles was zijn aandacht waard was, en zoo kon het niet anders, of herhaaldelijk pakte hij te veel onderwerpen tegelijk aan, die hij onmogelijk alle op even bevredigende wijze tot een goed einde kon brengen, terwijl, als hij zich op een gegeven moment aan één onderwerp wijdde, al de vele daar opdoemende details ook al weer alle evenzeer de moeite waard schenen om ze tot den grond na

1) Deel 45 (1928), p. 167.

$\left.{ }^{2}\right)$ De ontdekking van het adatrecht (1928), p. 147. 
te speuren, en het bij de vele aangetroffen problemen jammer leek om één mogelijkheid van oplossing te laten schieten.

Het compositie-gebrek van Rouffaer's artikelen is het compositiegebrek van Rouffaer's leven. Want het is precies dezelfde al te groote vrijheid, die hem op zijn tweede Indische reis van het eene belangwekkende verschijnsel naar het andere voerde en hem onder de Bataviasche epigraphica of het Filippijnsche letterschrift het groote boek, waarvoor hij op reis was gegaan, deed verzuimen. Het ligt voor de hand de verzuchting te slaken: wat zou een man met deze gaven, als hij zich in één richting had geconcentreerd, een geweldig werk hebben gewrocht. Maar men zou daarbij over het hoofd zien, dat juist zijn vermogen om telkens weer een onderwerp, dat hem trok, met zulk een hartstochtelijk doordringen te behandelen, het bijzondere van zijn werkkracht uitmaakte.

De ,onrustige veelzijdigheid” - het woord is weer van Van Eerde - is hem tot het slot van zijn wetenschappelijke loopbaan eigen gebleven. Er stonden nog allerlei studies op stapel, toen hij de pen uit de hand moest leggen, en zoo vindt men onder de nagelaten papieren reeds de omslagen gereed liggen, die nog te schrijven artikelen hadden moeten inhouden over het heilige kanon te Solo en over het wapen van Suriname, over den steen van Pasar Gĕde en over Bharāḍa's halveering van Java, over het goudland Beach en over de inlandsche restauratie van Leran, over den Agastya-berg in Travancore en den Diëng en over het Indonesisch van links naar rechts draaien, over den vogel als ziele-symbool en over de kluizenarij Marabangun. Van al deze stukken was alleen dat over Pasar Gĕḍe in wat verderen staat van voorbereiding; in de verklaring van het opschrift, welks vervaardiging aan Antonio Paulo werd toegeschreven, was Rouffaer grootendeels geslaagd.

Naast dit vele eigen werk staat dan het doen werken van anderen. Soms door rechtstreeksche aansporing, wanneer hij de uitwerking van een of ander punt, dat zonder deskundige hulp onoplosbaar was, met grooten aandrang verzocht; hij wist dat dan zóó in te kleeden, dat het uiterst moeielijk was om aan zijn , ik bid u" weerstand te bieden. Maar meer nog door anderen in gesprek of geschrifte te doen gevoelen, dat zij, en zij bepaaldelijk, iets goed, en waarschijnlijk beter dan een ander, zouden kunnen volbrengen, en dat zij er dus ook eigenlijk toe verplicht waren. Wat Rouffaer op deze wijze indirect heeft tot stand doen komen, is niet licht te overschatten. Wat al onderzoekingen op de velerlei terreinen, waar hij zelf zich voor 
interesseerde, zijn zoodoende op touw gezet, waarbij hij dan altijd gereed stond om ook het zijne bij te dragen en in alle moeielijkheden zijn raad te geven en zijn sympathie te toonen. Dat laatste was dan vooral van belang, waar hij menschen, die nog aan het begin van hun wetenschappelijke loopbaan stonden, of die zichzelf niet heel goed vertrouwden, deed verrichten wat zij vermochten. Velen zijn er hem, naar uit zijn correspondentie blijkt, dankbaar voor geweest, en het zal hem goed hebben gedaan, al sprak hij daar verder ook niet over, die waardeering te vernemen.

Maar dan waren er ook de gevallen, en daar had hij zelf nog veel meer plezier in, dat hij bijvoorbeeld iemand als prof. Kern er toe bracht over een onderwerp, dat hem ter harte ging, te schrijven, of dat hij zijdelings, door een quasi losse opmerking in een gesprek, of een zinsnede in een noot van een eigen artikel, een bepaalden persoon tot een bepaalde studie had weten te bewegen. Hoe kon hij er in gnuiven, een betere uitdrukking is er niet voor, als zulk een machinatie aan het doel bleek te hebben beantwoord!

Niet altijd echter lukte het zoo goed, en zelfs het directe betoog bleef wel eens zonder uitwerking. Niet zelden door Rouffaer's eigen toedoen; boordevol van allerlei in zijn oog hoogst belangrijke denkbeelden en plannen kon hij. daar den persoon, die er zich uithoofde van ambt of studie voor moest interesseeren, in zoodanige mate mee overstelpen, dat het resultaat negatief werd: de persoon in kwestie ging steeds flauwer reageeren en dit gaf aan Rouffaer de overtuiging, dat hij iemand tegenover zich had, die het eigenlijk niet waard was en die allen werkelijken studiezin miste. Die door teleurstelling ingegeven conclusie was veelal onbillijk, maar het kwam niet bij Rouffaer op, dat de onbevredigende gang van zaken ook wel aan hem zelf kon liggen, en zoo is er op dit gebied, naar uit zijn memoranda blijkt, misverstand blijven bestaan, dat onnoodig was geweest. Slechts een zeer enkele maal teekent hij later aan, dat hij een dergelijk geval klaarblijkelijk verkeerd heeft aangepakt. Doorgaans zat hij zoo met hart en ziel in het onderwerp, dat een mindere mate van geestdrift bij den toehoorder hem ongehoord scheen.

In zijn werk en in hetgeen een der correspondenten zijn ,bezielende kracht" voor anderen noemt, gaf hij zich volkomen, zonder reserve, met een geweldig enthousiasme en een zuivere toewijding. En ziedaar dan het derde punt, waarin hij wel zeer bijzonder was, zijn voorbeeld van volstrekt onbaatzuchtigen dienst der zelfgekozen levenstaak. Zelfgekozen? Eigenlijk slechts ten deele: wij haalden uit de 
Indische memoranda reeds die merkwaardige passage aan, waarin hij verklaarde, dat zijn neiging eigenlijk in andere richting ging, doch dat hij zich tot de Indische studiën had gewend, omdat andere werkers daar ontbraken, en hij voelde zelf krachtig werkzaam te kunnen zijn op dat gebied. Een plicht dus, meer dan een liefhebberij, maar dan een plicht niet van buiten af, maar van binnen in hem opgelegd.

In het vervullen van dien plicht, dien hij voelde als een persoonlijken maar nog meer als een nationalen plicht, eerst in de dagen van het Multatuli-boek tegenover de nagedachtenis van dien schrijver, later op een hooger plan tegenover Indië, als onderdeel van Nederland's verantwoordelijkheid, is hij voor zichzelf niet gemakkelijk geweest. Hij heeft getracht op zijn terrein naar het hoogst bereikbare te grijpen en was er zich maar al te goed van bewust, dat volgens de oude spretı - hoe gaarne haalde hij zelf waar het pas gaf klassieke citaten aan - de goden slechts voor inspanning het goede te koop bieden. Zoo heeft hij als het noodig was gezwoegd, en daarbij heeft de toestand zijner gezondheid hem vaak terneergedrukt, vooral inzoover het element van eigen vroegere onvoorzichtigheid hem tot het besef bracht, dat, ware het anders geloopen, een leven van onverzwakte werkkracht zijn deel had kunnen zijn.

Maar hoe verkeerd zou men doen, al waren er dan zulke dagen van depressie, door zich Rouffaer voor te stellen als den ter neer gedrukten, slechts uit plichtsgevoel voortarbeidenden zwoeger. Daarvoor bewaarde hem vooreerst zijn heerlijk enthousiasme, de warmte van zijn hart voor de studie, die hem lief was geworden, de onverwoestbare overtuiging dat wat hij onderhanden had van uitnemend belang was en ongetwijfeld tot een goed einde gebracht zou worden, en ook zijn verontwaardiging over slapheid, slinksheid en onbetrouwbaarheid, zijn vreugde over eigen vondsten en niet minder over het succes van anderen, want evenzeer als alle zucht tot wetenschappelijk monopoliseeren, was ook alle afgunst op wat anderen bereikten hem volkomen vreemd; ja sterker, het scheen wel of hij eigenlijk nog liever had dat een ander iets vond dan hij zelf, als ware het een verlichting van de eigen alomvattende taak, waarvan de ander een deel had overgenomen.

Daarnevens en daarmede in verband staande bezat hij een kostelijke eigenschap, die zoo goed gepeild is door dengene, die hem in de laatste jaren niet wetenschappelijk doch als vriend wel het naast heeft gestaan, den heer Teillers, in het fijne stukje dat deze eenige 
dagen na Rouffaer's dood in het Koloniaal Weekblad schreef ${ }^{1}$ ): diens intensief genieten van de wereld, als een tuin waar heerlijke ontdekkingen te doen waren en waar bonte vlinders hem lokten om te volgen. Het begrip wereld neme men dan zoo uitgebreid mogelijk en men vatte er gelijk de Boeddhist ook de onstoffelijke wereld onder. Wat de natuur voor hem (van jongsaf ook bloemenliefhebber bij uitstek) is geweest, de Hollandsche en de Italiaansche, maar even goed de Spaansche en de Indische, bleek hierboven, ook wat de kunst - zij het dan niet alle kunst —, de vaderlandsche en de HindoeJavaansche bovenal, voor hem heeft beteekend. Datzelfde vermogen tot intens genot strekte zich ook uit tot zijn wetenschappelijk werk; hij leefde daarin en vond er de levensvreugde, die hem in andere opzichten was ontzegd.

„Bij het terugzien op dit leven”, aldus nogmaals de heer Teillers, „nu, terwijl het pas is geëindigd, is men geneigd zichzelf af te vragen of men hem het ànders zou hebben toegewenscht, in de gewoonmenschelijke veronderstelling dat hij, als zoo oneindig velen, hèt eigenlijke, begeerenswaardige, de vervulling van zijn wenschen, alleen maar van verre, als een onbereikbaar beloofd land had gezien. Niets zou minder juist zijn, want, had mijn intuitie het me niet gezegd, ik zou het weten uit zijn eigen mond, deze mensch heeft geleefd en is ongetwijfeld ook uit het bewuste leven gescheiden in de dankbare verzekerdheid, dat het leven voor hem goed en schoon en heerlijk is geweest."

Inderdaad, dankbaarheid voor wat het rijke leven te genieten en te leeren geeft, en voor wat hij er zelf van had mogen genieten en leeren, was de grondtoon van zijn levensbeschouwing, en in die dankbaarheid heeft hij ook degenen, die hem nastonden, doen mededeelen. Dat was uit den aard der zaak een kleine kring, want op hoevelen hij ook middellijk invloed heeft uitgeoefend doordat zij met hem in aanraking waren gekomen of van hem gelezen of gehoord hadden als Rouffaer met zijn zweep klapte, heeft eens iemand met een bekend beeld uit den Pararaton gezegd, dan hoorde men het overal -, degenen die nauwer tot hem in betrekking stonden, waren slechts weinigen, vooral in de latere jaren van studeerkamerleven. Bij de eerste kennismaking was er zooveel, dat van het gewone afweek, in de al te rechtstreeksche vragen naar allerlei dat ver buiten eerstegesprekken lag en in zijn heele verdere soms wat wonderlijke op-

1) Nummer van 12 Januari 1928, p. 14. 
treden, en daar moest men eerst over heen komen. Doch voor wie hem werkelijk mochten leeren kennen, werd hij met al zijn onbewimpelde eerlijkheid naast al zijn teergevoeligheid tot een even zoo „,verkwikkende, tintelende verschijning” als Te Mechelen voor hemzelf geweest was en makte de verwondering voor een spontaan beantwoorde genegenheid plaats.

Met zulke persoonlijke gevoelens mag de herdenking in een wetenschappelijk tijdschrift echter niet eindigen. Is van hetgeen Rouffaer als wetenschappelijk werker tot stand bracht de balans al eenigszins op te maken? In zekeren zin zou dat natuurlijk geheel voorbarig zijn; de tijd zal leeren wat van de resultaten zijner vele onderzoekingen als definitieve uitkomst stand zal houden, en wat door latere wetenschap zal worden achterhaald. Toch kan men ook thans wel reeds constateeren, dat hij de kennis van Indië, historisch, ethnologisch, oudheidkundig, geografisch, door zijn wetenschappelijke exploratie op al deze gebieden, zijn doordringen tot verborgen bronnen, zijn scherpzinnige conclusies, ook menigmaal door zijn vergissingen, een groot stuk verder heeft gebracht. Daarnevens staat dan als nog meer dadelijk tastbaar en door den beoefenaar van Indische studiën ten onzent nooit genoeg te waardeeren resultaat zijner werkzaamheid de Koloniale Bibliotheek. De Indologische wetenschap in het algemeen en het Koninklijk Instituut in het bijzonder zijn aan Gerret Pieter Rouffaer veel, zeer veel verschuldigd.

\section{PUBLICATIES VAN Dr. ROUFFAER *) \\ (in chronologische volgorde) door W. C. Muller.}

Vier Kamper schilders, Ernst Maeler, Mechtelt toe Boecop, Bernard Vollenhove, Steven van Duyven. (Oud-Holland. IV, 1886, bl. 47-60; V, 1887, bl. 201-209, 295-308).

Oude schilderijen te Batavia. Met facsimiles. (Oud-Holland. XII, 1894, bl. 193-200). ${ }^{1}$ )

1) Dit artikel is gedagteekend: Pekalongan, 25 Aug. 1886. De Redactie teekent er bij aan: Door toevallige omstandigheden is deze bijdrage eenige jaren in portefeuille gebleven.

*) Wegens gebrek aan gegevens, zijn de vele artikelen door Dr. R. in couranten geschreven, met name bijv. in de Nwe Rott. Ct., buiten beschouwing gelaten. - Prof. Krom vestigt de aandacht op enkele artikelen; zie bl. 175 vgg. en 209 vgg. hiervóór. 
Spaansche indrukken. (De Gids. 1898, III, bl. 1-56).

Catalogus der land- en zeekaarten toebehoorende aan het Kon. Instituut voor de Taal-, Land- en Volkenkunde van Ned.-Indië. ('s-Gravenhage, Martinus Nijhoff. 1898).

Vragen over de Zuid-Dekhan'sche (Tamiel'sche) was-teekenkunst en verfkunst; vooral in verband met en in tegenstelling tot de op Java inheemsche. Met penteekeningen en staaltjes. ('s-Gravenhage, 1899). ${ }^{1}$ )

1) Gedrukt in nota-vorm, $18 \mathrm{blz}$. fol. Vermoedelijk opgesteld om gegevens te verkrijgen ten behoeve der groote batik-monographie. Deze vragenlijst is ook in het Engelsch vertaald.

Bespreking van: E. A. von Saher, De versierende kunsten in Nederlandsch Oost-Indië. (Tijdschr. Kon. Ned. Aardr. Gen. 1899, bl. 850$)$.

Matjan Gadoengan. (Bijdr. Kon. Inst. VI, 6, 1899, bl. 67-75).

Het tijdperk van godsdienstovergang $(1400-1600)$ in den Maleischen Archipel. 1e Bijdrage: Wanneer is Madjapahit gevallen? (Bijdr. Kon. Inst. VI, 6, 1899, b1. 111-199). ${ }^{1}$ )

1) Deze studie is onvoltooid gebleven.

[Voorwoord bij:] De val van de kraton van Padjang door toedoen van Senapati ( \pm 1586$)$, volgens de Babad Tanah Djawi. (Bijdr. Kon. Inst. VI, 6, 1899, bl. 284-289). ${ }^{1}$ )

1) Tekst van een H.S. van onbekende herkomst in de handschriftenverzameling van het Kon. Inst.

Een brutaal plagiaat [zijnde een h.s. van J. W. Winter over Soerakarta in 1824, nageschreven door den landmeter F. E. von Reichenbach von Schültz.] (Bijdr. Kon. Inst. VI, 6, 1899, bl. $315-330)$.

Waar kwamen de raadselachtige moetisalah's (aggri-kralen) in de Timor-groep oorspronkelijk van daan? [Eerste gedeelte.] (Bijdr. Kon. Inst. VI, 6, 1899, bl. 409-675). ${ }^{1}$ )

1) Deze studie is onvoltooid gebleven.

Een paar aanvullingen over bronzen keteltrommen in Ned.-Indië. (Bijdr. Kon. Inst. VI, 7, 1900, bl. 284-307).

Aanteekening omtrent zes photographieën, genomen naar drie zeldzame gebatikte katoenen kleedingstukken, en aangeboden aan het Bat. Genootschap. (Notulen Bat. Gen. 38, 1900, Bijl. VIII, bl. L-LXIV). 
L'industrie du ,batiq” à Java. (In : Exposition Univers. à Paris, 1900. Guide à travers la Section des Ind. Néerland. La Haye, 1900, bl. 292-298).

Over Indische batik-kunst, vooral die op Java. Met bijlagen en afb. (Bulletin Koloniaal Museum, No. 23, 1900, bl. 1-51).

„Oost en West”. [Catalogus der] Tentoonstelling van Indische kunstnijverheid. Groep III. Oost-Indische weefsels, Javaansche batik's en oud-Indische meubelen, Juli 1901. ('s-Gravenhage, Gebr. Giunta d'Albani, 1901).

Monumentale kunst op Java. (Naar aanleiding van: E. A. von Saher. De versierende kunsten in Ned. Oost-Indië. Eenige Hindoemonumenten op Java). (De Gids, 1901, II, bl. 225-252).

De „Archaeological Survey” in Britsch-Indië. (Tijdschr. Bat. Gen. 44, 1901, b1. 373-383).

De noodzakelijkheid van .een technisch-artistiek onderzoek in Ned.Indië. (Ind. Gids. XXIII, 1901, bl. 1186-1210; 1415-1416).

Register op de eerste 50 deelen (1850-1899) van de „Bijdragen tot de Taal-, Land- en Volkenkunde van Ned.-Indië”, uitgegeven door het Kon. Instituut, enz. ter gelegenheid van zijn 50-jarig bestaan op 4 Juni 1901. ('s-Gravenhage, Martinus Nijhoff, 1901).

Kunst uit Ned.-Indië [Bespreking van : Indonesian art. ... by C. M. Pleyte.] (De Nederlandsche Spectator, 1901, bl. 263-264).

Over Ikat's tjinde's, patola's en chiné's. Voordracht, uitgesproken op 31 Oct. 1901, op den dag der sluiting der Tentoonstelling van Oost-Indische weefsels enz. (te 's-Gravenhage). Met Naschrift. (Overgedrukt uit het Kol. Weekbl. van 7 Nov. 1901 en 11 Sept. 1902). ('s-Gravenhage, Uitg. Mij. „Gemeenschappelijk belang”. 1902).

[Catalogus der] Tentoonstelling van Oost-Indische weefsels en batik's. [Gehouden in het] Museum voor land- en volkenkunde en Maritiem museum „Prins Hendrik” te Rotterdam, April 1902. ('s-Gravenhage, Boek- en Steendrukkerij v/h H. L. Smits. 1902).

Eerste proeve van eene Rumphius-Bibliographie. ${ }^{1}$ ) (In: RumphiusGedenkboek. 1702-1902. Uitgegeven door het Koloniaal Museum te Haarlem 15 Juni 1902, bl. 165-220).

1) Geschreven, in samenwerking met W. C. Muller. 
[Voorwoord en Noten bij:] Beknopte beschrijving van het Hof van Soerakarta in 1824, door J. W. Winter. (Bijdr. Kon. Inst. VI, 10, 1902, V. bl. 15-25, N. bl. 99-172).

[Bespreking van:] Verslag van de 13e zitting van het Internationale Congres van Americanisten, gehouden te New-York van 10-25 Oct. 1902. (Onze Eeuw. 1903, II, bl. 1008-1012).

Een duistere plaats van Java's staatkundigen toestand tijdens Padjang \pm 1580 , opgehelderd. (In: Album-Kern. Opstellen geschreven ter eere van Dr. H. Kern ... op zijn 70en verjaardag. Leiden, E. J. Brill. 1903, bl. 267-274).

Een en ander over Tjandi Toempang. (Voordracht, gehouden in de 106e Alg. Verg. van het Kon. Ned. Aardr. Genootschap op 27 Dec. 1902). (Ind. Gids. XXV, 1903, bl. $164-196 .{ }^{1}$ )

1) Zie ook Tijdschr. Kon. Ned. Aardr. Gen. 2e Serie XX, 1903, bl. 308-310).

Laoet. (Bijdr. Kon. Inst. VII, 1, 1903, bl. 449-450).

[Register bij:] Gegevens over land en volk van Suriname, door C. van Coll. (Bijdr. Kon. Inst. VII, 1, 1903, bl. 641-650).

De voornaamste industrieën der Inlandsche bevolking van Java en Madoera. Aanhangsel tot het Overzicht van den economischen toestand der Inlandsche bevolking van Java en Madoera, door Mr. C. Th. van Deventer. [Koloniaal-Economische Bijdragen, $I^{a}$ ]. ('s-Gravenhage, Martinus Nijhoff. 1904).

Nieuwe wegen voor Indische volkenkunde. (Naar aanleiding van J. A. Loebèr Jr. ,Timoreesch snijwerk en ornament”, en „Rapport der Commissie van Advies betreffende 's Rijks Ethnographisch Museum”). (De Gids. 1904, I, bl. 271-310).

[Voorbericht ${ }^{1}$ ) en literatuuropgave bij:] Beschrijving van de ruine bij de desa Toempang, genaamd Tjandi Djago, in de residentie Pasoeroean. Samengesteld . . . . onder leiding van Dr. J. L. A. Brandes. ('s-Gravenhage, Mart. Nijhoff - Batavia, Albrecht en Co. 1904, V. bl. IX-XII; L. bl. 106-113). [Archaeologisch Onderzoek op Java en Madura, No. I.]

1) Dit Voorbericht is mede onderteekend door Prof. Dr. H. Kern.

[Naschrift en Bijlage op:] Toegift tot de "Gegevens over land en volk van Suriname”, door C. van Coll. (Bijdr. Kon. Inst. VII, 4, 1905, N. bl. 467-469, B. bl. 470-480).

Dl. 84. 
[Bespreking van:] Dr. G. A. F. Molengraaff. Geologisch onderwijs aan mijnbouwkundigen. [En:] Dr. J. F. van Bemmelen. Het goed recht der Palaeontologie aan een Polytechnische Hoogeschool. (Tijdschr. Kon. Ned. Aardr. Gen. 2e Serie, XXIII, 1906, bl. 1034-1042).

Uitzwerming van Javanen buiten Java. (Tijdschr. Kon. Ned. Aardr. Gen. 2e Serie, XXIII, 1906, bl. 1187-1190). ${ }^{1}$ )

1) Tekst eener op verzoek van $\mathrm{Mr}$. C. Th. van Deventer opgestelde Nota.

[Bespreking van:] Exposition Internationale d'Océanographie etc., à Marseille. Les Pays-Bas. (Tijdschr. Kon. Ned. Aardr. Gen. 2e Serie, XXIII, 1906, bl. 1194-1196).

De Chineesche naam Ts'e-ts'un voor Grěsik. (Bijdr. Kon. Inst. VII, 5, 1906, bl. 178-179).

De Hindostansche oorsprong van het „negenvoudig” Sultans-zegel van Atjeh, aangetoond o.a. door een merkwaardig Hindostansch schilderijtje van ca. 1700 . Tevens onder herkenning eener teekening van Rembrandt. (Met platen). (Bijdr. Kon. Inst. VII, 5, 1906, bl. 349-384).

De Indische verzameling te Bergum (Overgedrukt uit „Het Vaderland". 's-Gravenhage, $1906 .{ }^{1}$ )

1) Brochuretje van 9 bl., beschrijvend eene verzameling ethnographica van den oud-Ind. ambt. Van der Meulen.

Führer durch die Niederl.-Indische Kunst-Ausstellung im KaiserWilhelm-Museum zu Krefeld 1906. Krefeld, Kleinsche Druckerei. 1906. [Seite 40—-47 : Batikarbeiten, von G. P. Rouffaer.]

[Voorrede op:] W. O. J. Nieuwenkamp. Bali en Lombok, zijnde een verzameling... reisherinneringen en studies omtrent land en volk, enz. (Uitgegeven aan boord van „De Zwerver” [Edam], 1906-1910). ${ }^{1}$ )

1) Dit werk verscheen in drie gedeelten in de jaren 1906, '09 en '10. De Voorrede, bl. I-VII, is gedateerd Jan. 1906.

De palaeontologische onderzoekingstocht van mevr. M. L. Selenka naar Trinil (Madioen). (Tijdschr. Kon. Ned. Aardr. Gen. 2e Serie, XXIV, 1907, bl. 228-230).

[Bespreking van:] A. C. Kruyt, Het animisme in den Indischen Archipel. (Tijdschr. Kon. Ned, Aardr. Gen. 2e Serie, XXIV, 1907, bl. 266-271). 
[Voorwoord, met literatuuropgave op:] Onze Indische Financiën. Nieuwe reeks aanteekeningen, door E. de Waal. IX-X. Onze betrekkingen met... Noord-Borneo, uitgegeven door E. A. G. J. van Delden. ('s-Gravenhage, Martinus Nijhoff, 1907).

Catalogus der Koloniale Bibliotheek van het Kon. Instituut voor de Taal-, Land- en Volkenkunde van Ned. Indië en het Indisch Genootschap. ${ }^{1}$ ) ('s-Gravenhage, Martinus Nijhoff, 1908).

1) In samenwerking met W. C. Muller.

[Inleiding bij:] De Zuidwest Nieuw-Guinéa-expeditie 1904/5 van het Kon. Ned. Aardrijkskundig Genootschap. (Leiden, E. J. Brill. 1908, bl. XII--XXVI).

De aardrijkskunde in de Tweede Kamer. (Tijdschr. Kon. Ned. Aardr. Gen. 2e Serie, XXV, 1908, bl. 113-118).

De terugkeer en afloop der Lorentz-expeditie naar Centraal NieuwGuinea. Met kaart. (Tijdschr. Kon. Ned. Aardr. Gen. 2e Serie, XXV, 1908, bl. 133-144).

De Javaansche naam „Seran” van Z. W. Nieuw-Guinea vóór 1545; en een rapport van Rumphius over die kust van 1684. (Tijdschr. Kon. Ned. Aardr. Gen. 2e Serie, XXV, 1908, bl. 308-347).

De aanstaande 6de expeditie van het Kon. Ned. Aardrijkskundig Genootschap naar het binnenland van Suriname. (Tijdschr. Kon. Ned. Aardr. Gen. 2e Serie, XXV, 1908, bl. 567-571).

De nieuwe Linschoten-vereeniging; eene Nederlandsche Hakluyt Society. (Tijdschr. Kon. Ned. Aardr. Gen. 2e Serie, XXV, 1908, bl. 622-625).

Het gereedkomen der Nieuw-Guinea-uitgave van het Kon. Ned. Aardr. Genootschap. Met kaart. (Tijdschr. Kon. Ned. Aardr. Gen. 2e Serie, XXV, 1908, bl. 872-876).

Penis-gordels behalve op Nieuw-Guinea c.a., ook in Brazilië. (Tijdschr. Kon. Ned. Aardr. Gen. 2e Serie, XXV, 1908, bl. 1199-1201).

De vervulling der beide professoraten voor aardrijkskunde aan de Utrechtsche Universiteit. (Tijdschr. Kon. Ned. Aardr. Gen. 2e Serie, XXV, 1908, bl. 1383-1385).

Junghuhn, niet in Oct. 1812 geboren, maar in Oct. 1809. (Tijdschr. Kon. Ned. Aardr. Gen. 2e Serie, XXV, 1908, bl. 1409-1411). 
Tot afscheid, bij de overdracht van het Secretariaat T. A. G. (Tijdschrift Kon. Ned. Aardr. Gen. 2e Serie, XXV, 1908, bl. 1422 -1424).

De drie opvaarten der Mambèråmo (Noord-Nieuw-Guinea), Juli 1884, Jan. 1900 en Juni 1906. Met kaart en bijlagen. (Tijdschr. Kon. Ned. Aardr. Gen. 2e Serie, XXVI, 1909, bl. 86-128).

Het plan tot samenstelling van een Batak-spiegel; iets nieuws op Indisch gebied. ('Tijdschr. Kon. Ned. Aardr. Gen. 2e Serie, XXVI, 1909, bl. 138-140).

Een Engelsche expeditie naar Nederlandsch Zuid-Nieuw-Guinea. (Tijdschr. Kon. Ned. Aardr. Gen. 2e Serie, XXVI, 1909, bl. 294-298).

De oude en de nieuwe monding der Sadangrivier (Centraal-Celebes).

(Tijdschr. Kon. Ned. Aardr. Gen. 2e Serie, XXVI, 1909, bl. $841-844)$.

[Voorwoord bij:] De jongste opvaart der Mamberåmo, 23 Juni-9 Juli 1909, door F. L. Rambonnet. (Tijdschr. Kon. Ned. Aardr. Gen. 2e Serie, XXVI, 1909, bl. 946-947).

Herdenking van Dr. J. L. A. Brandes $†$ Zo. nacht 26 Juni 1905 te Batavia. Met portret en afb. grafmonument. (In: Beschrijving van Tjandi Singasari, enz. Samengesteld... onder leiding van wijlen Dr. J. L. A. Brandes). ('s-Gravenhage, Mart. NijhoffBatavia, Albrecht en Co. 1909, bl. I*-XLVI*). [Archaeologisch Onderzoek op Java en Madura. II]. ${ }^{\mathbf{1}}$ )

1) Voor het belangrijke aandeel van Dr. R. in de samenstelling dezer monographie zie Prof. Krom, bl. 236-237 hiervóór.

Een bezoek aan de Topografische Inrichting te Batavia. (Tijdschr. Kon. Ned. Aardr. Gen. 2e Serie, XXVI, 1909, bl. 773-788).

Lijst der beschreven steenen (D. 1-116), op ulto. Dec. 1909 aanwezig in het Museum van het Bataviaasch Genootschap van $\mathrm{K}$. en W. (Notulen Bat. Gen. 47, 1909, Bijl. XII, bl. LXXVIILXXXV).

De ouderwetsch-Javaansche koedi, nog algemeen op Madoera in zwang. Met platen. (Tijdschr. Bat. Gen. 51, 1909, bl. 471-476).

Zijn er nog Hindoe-oudheden in Midden-Borneo aan de Boven-

Sĕkadau? (Tijdschr. Bat. Gen. 51, 1909, bl. 456-469). 
De plaats en datum van geboorte van Dr. H. Neubronner van der Tuuk. (Bijdr. Kon. Inst. VII, 9, 1910, bl. 172-175).

Het grafmonument van Junghuhn. Met afbeelding. (In: Gedenkboek Franz Junghuhn 1809-1909. 's-Gravenhage, Martinus Nijhoff. 1910, bl. 357-361).

De verder-ontdekking van Ned. Nieuw-Guinea. (Tijdschr. Kon.

Ned. Aardr. Gen. 2e Serie, XXVII, 1910, bl. 134-139).

Aan Junghuhn's graf. (Tijdschr. Kon. Ned. Aardr. Gen. 2e Serie, XXVII, 1910, bl. 261-263).

Verandering der monden van de Peusanganrivier, Noord-Atjeh. (Tijdschr. Kon. Ned. Aardr. Gen. 2e Serie, XXVII, 1910, bl. 564-568).

Aanteekeningen bij de schetskaart van Portugeesch-Timor. Met kaart. (Tijdschr. Kon. Ned. Aardr. Gen. 2e Serie, XXVII, 1910, bl. 794-796, 1303).

Foutieve vermelding van berghoogten op schetskaarten der Buitenbezittingen. (Tijdschr. Kon. Ned. Aardr. Gen. 2e Serie, XXVII, 1910, bl. 787-790).

De uitbarsting van den Lobetobi Laki-laki (Oost-Flores) op 23 Jan. 1910. (Tijdschr. Kon. Ned. Aardr. Gen. 2e Serie, XXVII, 1910, bl. 797-799).

De Ili Werroeng. Een onbekende werkende vulkaan op Lomblen's Zuidoostkust. (Tijdschr. Kon. Ned. Aardr. Gen. 2e Serie, XXVII, 1910, bl. 1026-1028).

De Inyĕ Lika op de hoogvlakte van Ngada, Midden-Flores. Met kaart en platen. (Tijdschr. Kon. Ned. Aardr. Gen. 2e Serie, XXVII, 1910, bl. 1233-1239).

Zeldzame gouden Mĕmoeli van Soemba. Met plaat. (Notulen Bat. Gen. XLIX, 1911, Bijl. II, bl. XXIX-XXXI).

[Slotnoot bij:] Friderici Bollingii Oost-Indisch Reisboek. (Bijdr. Kon. Inst. 68, 1913, bl. 379-381).

De Maleische woorden katji, tjĕngkoerai, en tjindai verklaard. (Bijdr. Kon. Inst. 68, 1913, bl. 422-428).

De batikkunst in Nederlandsch-Indië en haar geschiedenis. Op grond van materiaal aanwezig in 's Rijks Ethnographisch Museum en andere openbare- en particuliere verzamelingen in Nederland, 
bewerkt door G. P. Rouffaer en Dr. H. H. Juynboll. 2 dln., nl. 1 dl. tekst en 1 dl. platen. (Utrecht, A. Oosthoek. 1914). [Hollandsche en Duitsche tekst.] ${ }^{1}$ )

1) Dit werk is (als Publicatie van 's Rijks Ethnographisch Museum. Serie II, No. 1) in vijf afleveringen verschenen; afl. 1 in 1900, II in 1901, III in 1904, IV in 1905, alle bij de firma H. Kleinmann en Co. te Haarlem, en afl. V (waarmede het werk compleet was) in 1914 bij Oosthoek.

De landkaart van Soembawa. [Naschrift op enkele onnauwkeurigheden op zeekaarten van Soembawa, door J. J. Pannekoek van Rheden]. (Tijdschr. Kon. Ned. Aardr. Gen. 2e Serie, XXXI, 1914, bl. 779-781).

Een curieus Duitsch boekje over Onze Oost uit 1646. (Bijdr. Kon. Inst. 69,1914 , bl. 127-129).

De eerste schipvaart der Nederlanders naar Oost-Indië onder Cornelis de Houtman 1595-1597. Journalen, documenten en andere bescheiden uitgegeven en toegelicht door G. P. Rouffaer en J. W. IJzerman. I. D'eerste boeck van Willem Lodewycksz. II. De oudste journalen der reis, enz. ('s-Gravenhage, Martinus Nijhoff. 1915, 1925). 2 dln. Met portretten, platen en kaarten. [Werken uitgegeven door de Linschoten-Vereeniging. VII, $\mathrm{XXV}$.]

Oud-Javaansche eilandnamen in de Groote Oost [Sĕrgili, Seran, Boeroe]. (Tijdschr. Kon. Ned. Aardr. Gen. 2e Serie, XXXII, 1915, bl. 642-649).

Nota over het Bibliotheekwezen in Nederlandsch West-Indië. ${ }^{1}$ ) (Bijdr. Kon. Inst. 71, 1916. Bijlage Not. Best. Verg. bl. XXIXXXVII).

1) Opgesteld in samenwerking met Prof. Mr. C. van Vollenhoven.

Nieuwenkamp's vierde reis naar Onze Oost. Met portret en ill. (Ned. Indië Oud en Nieuw. II, 1917-18, bl. 229-231).

Charles te Mechelen. In memoriam. Met portret en ill. (Ned. Indië Oud en Nieuw, II, 1917-18, bl. 305-312).

Chineesche invloeden op Javaansche kunst. Met afb. (In: Gids voor de verzameling van Indonesische en Chineesche kunst te Leeuwarden 1917). (Leeuwarden, Coöp. Handelsdrukkerij. 1917, bl. $11-20)$. 
De agrarische rechtstoestand der Inlandsche bevolking op Java en Madoera. Rapport uitgebracht aan Mr. C. Th. van Deventer, op 16 April 1904. (Bijdr. Kon. Inst. 74. 1918, bl. 305-398).

Oudheidkundige opmerkingen (met tekstillustratie). [I. Bangka, het „Schip”-eiland. II. Parāwis in 608 Çaka = Bangka? III. De Regentes-Vorstin Sima in Kẹḍoe. IV. Rijksbestierder-Vorst Daksha en Tjandi Prambanan. V. Een zeldzame hulde aan Rijksbestierder Gadja(h)mada in 1265.] (Bijdr. Kon. Inst. 74, 1918, bl. 138-166).

[Inleiding bij:] Het Oosten in vogelvlucht, van Boeddha tot de Groot-Mogols, door wijlen M. van Geuns. (Indische Gids. 41, 1919, bl. 328-333).

Was Malaka emporium vóór 1400 A.D., genaamd Malajoer? En waar lag Woerawari, Mā-Hasin, Langka, Batoesawar? (met terreinschetsen van Djambi, oud-Singhapoera en de Djohorrivier). (Bijdr. Kon. Inst. 77, 1921, bl. 1-174, 359-604).

Van Hoëvell's archaeologische reis in Midden-Java van 1840. (Bijdr. Kon. Inst. 79, 1923, bl. 591-597).

Naschrift over het Oud-Portugeesche fort op Poeloe Ende; en de Dominikaner Solor-Flores-Missie, 1561-1638. Met plattegronden en kaart. (Ned. Indië Oud en Nieuw. VIII, 1923-24, bl. $121-128 ; 141-148)$.

Chronologie der Dominikaner-Missie op Solor en Flores, vooral Poeloe Ende, ca. 1556-1638; en bibliographie over het Endefort. Met plattegrond. (Ned. Indië Oud en Nieuw. VIII, 1923 -24 , bl. 204-222; 256-260).

\section{ENCYCLOPAEDIE VAN NEDERLANDSCH-INDIE.}

Eerste druk. Deel II (1899).

Kunst (Beeldende), bl. 324-336.

Deel III (1902).

Sarong, bl. $518-520$.

Schilderkunst, bl. 559-561.

Smeedkunst, bl. 628-634. 


\section{Deel IV (1905).}

Soenda. Soenda-eilanden (Groote en Kleine), bl. 16-19.

Tandak, bl. 261-262.

Tenggereezen, bl. 293-302.

Tiele (Pieter Anton), bl. 323-324.

Tochten (Oudste ontdekkings-) tot 1497, bl. 363-395.

Tijdrekening, bl. 445-460.

Vaartuigen, bl. 476-489. ${ }^{1}$ )

Valentijn (François), bl. 493-498. ${ }^{2}$ )

Vorstenlanden, bl. 587-653.

Tweede druk. Deel I (1917).

Barbosa (Duarte), bl. 168-169.

Batikken, bl. 192-203.

Bik (A. J. en J. Th.), bl. 302-303.

Bor (Livinus), bl. 354-355.

Chastelein (Cornelis), bl. 473-474.

\section{Deel II (1918).}

Heydt (Johann Wolffgang), bl. 93-94.

Hoofddoek, bl. 105-106.

Huet (Conrad Busken), bl. 110-112.

Ikatten, bl. 132-134.

Jacquet (Eugene Vincent Stanislas), bl. 177.

Jager (Herbert de), bl. 177-178.

Kain Kĕmbangan, bl. 248-249.

Kanigårå, bl. 268.

Kasang, bl. 280.

Kĕmbĕn, bl. 297.

Keteltrommen (Bronzen), bl. 305-310.

Kinsbergen (Isidore van), bl. 324-325.

Koeloek, bl. 366-367.

Kopjah, bl. 429-430.

Kota Intěn, bl. 438-439.

Krawangan, bl. 450.

Lavanha (João Baptista), bl. 537-538.

Leran, bl. 570.

Leyden (John), bl. 575-576.

1) In samenwerking met P. C. Coops.

2) In samenwerking met W. C. Muller. 
Lotus, bl. 623-624.

Mechelen (Henri Louis Charles te), bl. 691.

Deel III (1919).

Padjadjaran, bl. 243-244.

Padjang, bl. 244-245.

Padtbrugge (Robert), bl. 247.

Paludanus (Bernardus), bi. 274-275.

Paravicini (Joannes Andries), bl. 341-342.

Pata Lima, Pata Siwa, bl. 360-361.

Pegoeanen in den Maleischen Archipel (Pégon), bl. 371-372.

Pěndåpå, bl. 380-381.

Pfeiffer (Ida), bl. 403.

Pigafetta (Antonio), bl. 407-408.

Pinto (Fernão Mendes), bl. 410.

Plancius (Petrus), bl. 415-418.

Plangi, bl. 418-420.

Polanen (Rogier Gerard van), bl. 441.

Pomp (Dirck Gerritz), bl. 448-449.

Saroeng, b1. 703-704.

Schilderkunst, bl. 718-720.

Deel IV (1921).

Soenda; Soenda-eilanden (Groote en Kleine), bl. 14-20.

Soerakarta, alias Batavia, bl. 37-38.

Soerasowan, alias ook Soerasadji, bl. 38-39.

Tandak, bl. 257.

Tapih, bi. 277-278.

Tĕmpajan, bl. 296.

Tenggereezen, bl. 298-308.

Tiele (Pieter Anton), bl. 335-336.

Tjakalélé, bl. 366.

Tjindai, Tjindé, bl. 374 .

Valentijn (François), bl. 501-508. ${ }^{1}$ )

Wètangers, bl. 765-766.

1) In samenwerking met W. C. Muller. 